Portland State University

PDXScholar

$1-1-1975$

\title{
Is there a case for in-kind income transfers?: an analysis of the low-income housing and food stamp programs
}

Judy Barmack

Portland State University

Follow this and additional works at: https://pdxscholar.library.pdx.edu/open_access_etds Let us know how access to this document benefits you.

Recommended Citation

Barmack, Judy, "Is there a case for in-kind income transfers?: an analysis of the low-income housing and food stamp programs" (1975). Dissertations and Theses. Paper 73.

https://doi.org/10.15760/etd.73

This Dissertation is brought to you for free and open access. It has been accepted for inclusion in Dissertations and Theses by an authorized administrator of PDXScholar. Please contact us if we can make this document more accessible: pdxscholar@pdx.edu. 
IS THERE A CASE FOR IN-KIND INCOME TRANSFERS?

AN ANALYSIS OF THE LOW-INCOME HOUSING AND FOOD

STAMP PROGRAMS

By

Judith A. Barmack

A dissertation submitted to the Faculty of Urban Studies in partial fulfillment of the requirements for the degree of

DOCTOR OF PHILOSOPHY

Portland State University 1975

Copyright (C) 1975 by Judith A. Barmack 
TO THE OFFICE OF GRADUATE STUDIES AND RESEARCH:

The members of the Committee approve the dissertation of Judith A. Barmack presented May 30, 1975 .
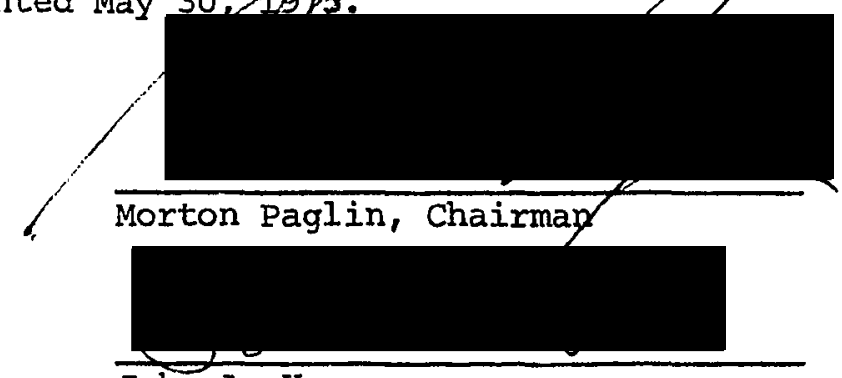

John A. Hanson
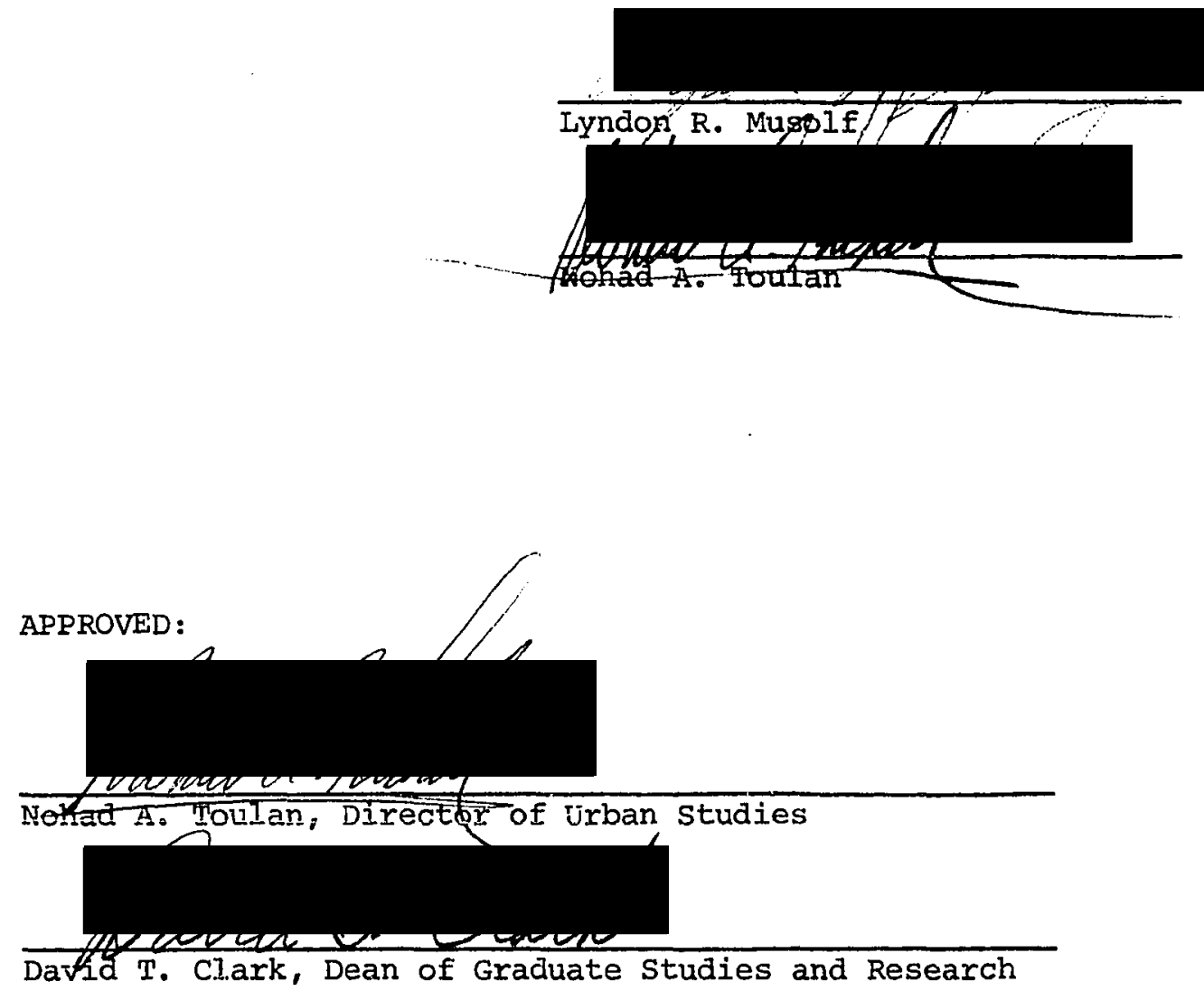

May 30, 1975 
AN ABSTRACT OF THE DISSERTATION OF Judith A. Barmack for the Doctor of Philosophy in Urban Studies presented May 30, 1975.

Title: Is There a Case for In-Kind Income Transfers? An Analysis of the Low-Income Housing and Food Stamp Programs

APPROVED BY MEMBERS OF THE DISSERTATION COMMTITYTEE:
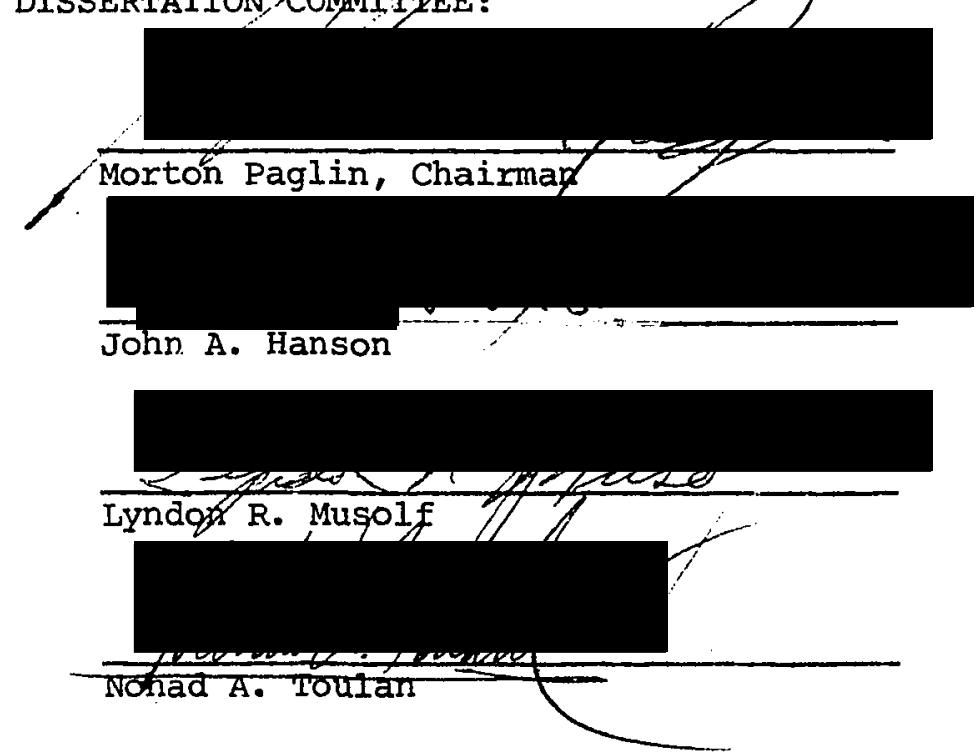

The primary objective of this research was to assess the equity and efficiency of in-kind income transfers. The analytical framework employed incorporated key concepts of the utility interdependence paradigm from economic welfare theory. This paradigm views income transfers as social goods and suggests that social as well as private benefits may be derived from the redistribution of income. This study attempted to assess some of the empirical implications of the utility interdependence argument through the investigation of the low-income housing and Food Stamp programs in Multnomah County, Oregon for FY 1973. 
Data were drawn from agency files, published statistics and documents, interviews with program administrators, and a survey of the records of 498 Non-Public Assistance Food Stamp households. The private and social benefits and costs of the programs were estimated. The program $\mathrm{r} x$ ticipation rates and the socio-economic characteristics of recipient households were ascertained. Particular attention was devoted to an evaluation of the efficacy of in-kind transfers in inducing substituxion effects or producing social benefits through the alteration of the consumption patterns of the target population. In addition to an economic analysis of in-kind transfers, the political environment of welfare legislation was detailed.

The results of this research suggest that in-kind income transfers are an inefficient and inequitable method of redistributing income. All programs investigated were characterized by high administrative costs. The administrative share of the public program budget ranged from $20 \%$ in the Food stamp Program to over 50\% in Puillic Housing. All programs were found to be inequitable in that households with similar socio-economic characteristics did not receive similar benefits. Housing programs discriminate among the equally needy by restricting supply. In the Food Stamp Program, a complex income determination formula, which is used to calculate program benefits, results in a considerable variation in the subsidies provided to households of equivalent size and income.

The low-income housing and Food Stamp programs were also found to be ineffective in producing those social benefits which are specifically related to changes in the consumption patterns of the target population 
as a whole. While housing programs were found to induce substitution effects by furnishing large subsidies to a small number of households, only 5 of of the eligible received benefits. Programs which leave the vast majority of the poorly housed untouched were judged unlikely to significantly diminish the external diseconomies presumed to be associated with the housing expenditure patterns of the entire population of eligible. In contrast, the Food Stamp Program provides less generous subsidies to all eligible appiicants. Food stamp subsidies were found to be insufficient to generate substitution effects; the food consumption patterns demanded of recipient households were not different from the food expenditure patterns of comparable households with income entirely in cash.

While the distribution of benefits in the housing and Food stamp programs strongly favors the poor, large numbers of non-poor are officially eligible for assistance. It was estimated that $37 \%$ of the households in the country were eligible for low-income housing and approximately $46 \%$ were eligible for food stamps. While the tight supply of housing transfers limits the growth of program participation, an enormous expansion of participation in the open-ended Food stamp Program is possible.

The economic analysis of in-kind transfer programs emphasized their deficiencies as redistributive mechanisms. However, the political potency of in-kind programs was found to be considerable. Policy-makers appear to be responsive to pressures to perpetuate and expand established programs, rather than to empirically validate the assumptions which they are based. In view of the political popularity of 
in-kind transfers and the public antipathy to transfers of cash, it is probable that transfers in-kind will command an increasing share of the welfare budget. 


\section{ACKNOWLEDGEMENTS}

It is a pleasure to thank the members of my committee for their contributions to this work. Dr. Morton Paglin, chairman, provided invaluable assistance. His model of scholarship, his infectious enthusiasm for his work, and his demanding standards evoke the best efforts of others. Dr. Nohad A. Toulan, Director of the Urban Studies Frograms, has generously supported my endeavors in numerous ways. He is to be commended for dramatically improving the working environment in our program in a very short period of time. Dr. Lyndon R. Musolf, Director of the Housing Authority of Portland, stimulated my interest in Public Administration through his seminars. My work has benefitted directly from his commitment to opening the Housing Authority to academic investigators. Dr. John A. Hanson, another valued committee member, provided an excellent introduction to the economic aspects of public policymaking and was always available to answer questions. Acknowledgements are also owed to Mr. Willard Renkin, Food Stamp Coordinator for Multnomah County, who facilitated the survey of Food stamp households; to Ms. Gwen Newborg, Portland State University Documents Librarian, who skillfully located obscure materials in the maze of governnent publications; and to Ms. Kristen Ludwig and Ms. Cyd Saint-James. who devoted many hours to the survey. 
Special thank yous are in order for my tolerant family; to my parents who promoted the development of the distaff side of the family long before it became the thing to do; to my sons, Matthew and Erik, who remind me of the futility of pricing intangibles; and most of all to Neal, my loving husband and most perceptive critic -- his example of excellence in his own work has been vital to mine. 
TABLE OF CONTENTS

PAGE

ACKNOWLEDGEMENTS . . . . . . . . . . . . . . . . .

LIST OF TABLES . . . . . . . . . . . . . . . . . viii vi v

LIST OF FIGURES. . . . . . . . . . . . . . . . . . xiii

CHAPTER

I THE AMERICAN WAY OF WELFARE . . . . . . . . . . 1

Introduction .............. . . 1

Administrative Issues. . . . . . . . . 7

Diffusion of Responsibility and Variations in standards

Complexity, Error and Fraud

staff Shortages and High Turnover

Perverse Incentives. . . . . . . . . .

Barriers to the Participation of the Eligible: High Participation and Transaction Costs

Work Disincentives: High Marginal Tax Rates and Notches

Work Disincentives: High Potential Benefit Levels

Family Break-Up

Explanation for Chaos? Welfare Politics . .

II WELFARE THEORY AND THE IMPLICATIONS OF UTILITY INTERDEPENDENCE $\ldots \ldots$

Introduction. . . . . . . . . . . .

From the Social Welfare Function to utility Interdependence. . . . . . . . .

Goods-Specific Utility Interdependence: The Case of Merit Goods. . . . . . . . . 
The Effects of Transfer Modes on Consumption Patterns . . . . . . . . .

Criticisms of the Utility Interdependence Framework . . . . . . . . . . .

III TRANSFERS IN-KIND: BACKGROUND MATERIAI ON THE LOW-INCOME HOUSING AND FOOD STAMP PROGRAMS

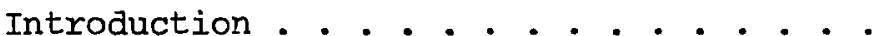

Low-Income Housing Policy. . . . . . .

Goals and Backgrolind

Housing Market Condition : Supply and Demand Elasticity

Low-Income Housing Programs: Description and Criticisms

The Food stamp Program . . . . . . .

The Politics of Hunger

Program Mechanics

Program Criticisms

Hypotheses to be Tested. . . . . . .

Problems in Evaluating Public Programs . .

A Model for Evaluating In-Kind Transfers .

$V$ AN EMPIRICAL INVESTIGATION OF IN-KIND TRANSFERS:

THE CASE OF LOW-INCOME HOUSING . . . .

Program Costs. . . . . . . . . . .

Market Value . . . . . . . . .

Private Benefits: The Cash Value of Public Housing to Tenants. . . . . . . .

Participation Rates. . . . . . . . .

Distribution of Private Benefits: Characteristics of HAP Tenants. . . . . . 
Evaluating Housing Subsidies . . . . .

Summary. . . . . . . . . . . . .

VI AN EMPIRICAL INVESTIGATION OF IN-KIND TRANSFERS: THE CASE OF FOOD STAMPS. . . . . . . . . 152

Program Costs. . . . . . . . . . 152

Market value . . . . . . . . . . 163

Private Benefits: Cash Value of Food stamps to Recipients . . . . . . . . . . 164

Distribution of Private Benefits: Recipient Characteristics......... 166

Estimating the Number of Eligible. . . . . 184

Evaluating Food Stamp Subsidies. . . . . 190

summary. . . . . . . . . . . . 194

VII CONCLUSIONS . . . . . . . . . . . . 196

High Admiristration and Participation Costs. 196

Substitution Effects.......... 199

Equity . . . . . . . . . . . 202

Non-Economic Issues. . . . . . . . . 203

REFERENCES. . . . . . . . . . . . . . . . 207

Books and Articles... . . . . . . . . 207

Government Publications. . . . . . . . . . 211

Newspaper Articles . . . . . . . . . . 217 
I Expenditures in Public Needs-Tested Income Transfer Programs, Selected Years . . . . . 2

II Expenditures and Participation in Public NeedsTested Income Transfer Programs, F.Y. 1973. . .

III Annual Benefits for Household with Employable Head, by Work Status, (as of July, 1972), Husband, Wife and Two Children, Selected counties. .

IV Rates of Change in the Consumer Price Index, the Price of Food at Home Index, Food Stamp Bonuses and AFDC Payments, F.Y. 1971-1974 . . . . . .

V Food Stamp Bonuses and AFDC Payments, U.S. and Selected States . . . . . . . . . .

VI Development costs, Conventional Public Housing, Portland, Oregon, 1938-1972 ........ 109

VII Development Costs, Turnkey Public Housing, Portland, Oregon, 1938-1972 . . . . . . . .

VIII Modernization Costs, Conventional Public Housing, 1969-1972 ...............

IX Capital Subsidies, Conventional and Turnkey Public Housing, Portland, Oregon, 1972 . . . . . .

x Operating Receipts and Expenditures, Conventional Public Housing, Portland, Oregon, April 1, 1972 March 31, 1973. . ........... 
XI Operating Expenditures, Turnkey Public Housing, Portland, Oregon, April 1, 1972-March 31, 1973 . Operating Receipts and Expenditures, Leased IowIncome Housing, Portland, Oregon, April 1, 1972$\operatorname{March~31,~} 1973$. . . . . . . . . .

XIII Operating Subsidies, Convencional and Turnkey Public Housing, Leased Iow-Income Housing, Portland, Oregon, April 1, 1972-March 31, 1973 . . 120

XIV Property Tax Subsidies, Conventional and Turnkey Public Housing, Portland, Oregon, April 1, 1972-

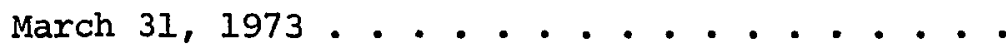

XV Housing Subsidies per Unit, Conventional, Turnkey and Leased Low-Income Housing, Portland, Oregon, April 1, 1972-March 31, 1973. . . . . . 123

XVI Selected Methods of Estimating the Market Value of Public Housing Units, Portland, Oregon, 1972 . . 126

XVII Estimated Market Value, Iow-Income Leased Housing Portland, Oregon, 1972 . . . . . . . . . 128

XVIII Estimated Gross Monthly Rent by Family size and Income Class, Urban United States, 1972. . . . 130

XIX Housing Authority of Portland, Eligibility Limits, 1972 . . . . . . . . . . . . . .

Xx Annual Money Income by Household Size, Multnomah County, Oregon, 1970 . . . . . . . . . 
XXI Estimated Number of Households Eligible for Low-Income Public or Leased Housing, by Household Size and Income, Multnomah County, Oregon, 1972 . . . . . . . . . . . . . . . .

XXII Iow-Income Thresholds for Nonfarm Households by Household Size, U.S., 1972 and Housing Authority of Portland Iow-Income Housing Eligibility Limits. 136

XXIII Characteristics of Tenants: Income and Source of Income, Housing Authority of Portland, 1973. . .

XXIV Characteristics of Tenants: Household Size, Housing Authority of Portland, 1973. . . . . . 139

XXV Characteristics of Tenants: Age, Sex, and Race of Head, Housing Authority of Portland, 1973. . . . 140

XXVI Low-Rent Public Housing, Characteristics of Households Reexamined for Continuing Occupancy During Twelve Months Ended September 30, 1972, U.S. . .

XXVII Housing Authority of Portland, Monthly Rent schedules, 1972 . . . . . . . . . . . . . .

XXVIII Direct Food Stamp Program Costs, Multnomah County, Oregon, FY 1973. . . . . . . . . . . . .

XXIX Monthly Food Stamp Coupon Allotments, Purchase Requirements, and Eligibility Limits, 48 states and District of Columbia, Effective July 1, 1972 . . 
XXX Monthly Food stamp Coupon Allotments, Purchase Requirements, and Eligibility Iimits, 48 states and District of Columbia, Effective July 1, 1974.

XXXI U.S. Department of Agriculture, Food Stamp Program Costs, U.S., FY 1973 . . . . . . . . . 160

XXXII Estimated Monthly Food Expenditures by Household Size and Income Class, Urban U.S., Fiscal Year 1973.................. . 165

XXXIII Characteristics of Non-Public Assistance Food Stamp Recipients: Household Size, Sex, and Age of Head, Multnomah County, Oregon, Dec. 1974 . . 169 XXXIV Characteristics of Non-Public Assistance Food Stamp Recipients: Assets, Multnomah County, Oregon, December, 1974 . . . . . . . . . . .

XXXV Characteristics of Non-Public Assistance Food Stamp Recipients: Gross Monthly Income, Net Monthly Income, and Bonus Value, by Household Size, Multnomah County, Oregon, December, 1974. • 172 XXXVI Characteristics of Non-Public Assistance Food Stamp Recipients: Gross Monthly Income by Household Size and Income Class, Multnomah County, Oregon, December, 1974 . . . . . . . . . . . 
XXXVII Characteristics of Non-Public Assistance Food Stamp Recipients: Net Monthly Income for Food Stamps by Household Size and Gross Income class, Multnomah County, Oregon, December, 1974 .... 174 XXXVIII Characteristics of Non-Public Assistance Food Stamp Recipients: Monthly Food Stamp Bonus by Household Size and Income Class, Multnomah County, Oregon, December, 1974 . . . . . . 175 XXXIX Characteristics of Non-Public Assistance Food Stamp Recipients: Deductions from Gross Income Sources, Multnomah County, Oregon, December, 1974180

XL Characteristics of Non-Public Assistance Food Stamp Recipients: Excess Shelter Deductions by Household Size and Income Class, Multnomah County, Oregon, December, 1974 . . . . . . . 181

XLI Low-Income Thresholds for Nonfarm H Paseholds and Food Stamp Eligibility Limits, by Household Size,

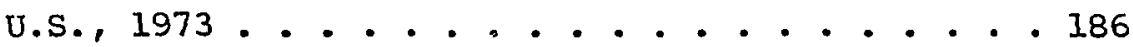

XIII Estimated Number of Households Eligible for Food Stamps, by Household Size and Income, Multnomah County, Oregon, FY 1973. . . . . . . . 189 
1 The Impact of Cash and In-Kind Transfers on Housing Consumption . . . . . . . . 38

2 A Model for Evaluating In-Kind Transfers. . . 103

3 Impact of Housing Subsidies on Two-Person, Elderly Household in Turnkey or Leased Unit,

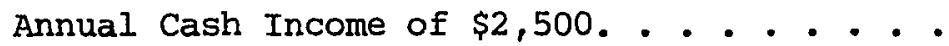

4 Impact of Housing Subsidies on Four-Person Household in Conventional or Leased Unit,

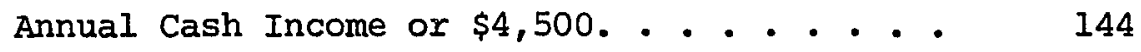

5 Characteristics of Non-Public Assistance Food Stamp Recipients: Net and Gross Income. 176

6 Characteristics of Non-Public Assistance Food Stamp Recipients: Gross Income and Bonus . . 178

7 Characteristics of Non-Public Assistance Food Stamp Recipients: Gross Income and Shelter Deductions... . . . . . . . . . . . .

8 Impact of Food Stamps on Two-Person Household, Annual Cash Income of $\$ 2,500 . . . . . . .191$

9 Impact of Food Stamps on Four-Person Household,

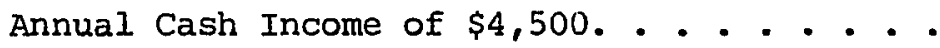


CHAPTER I

THE AMERICAN WAY OF WELFARE

Introduction

The American welfare system pleases neither the taxpayer nor the intended beneficiaries of public income transfers. Taxpayers grumble about cost escalation, inefficiency, and fraud while those eligible for benefits complain of inequities, inadequate payment levels and stigmatization. The swift escalation of expenditures and glaring malfunctions in several public needs-tested income transfer programs have stimulated considerable debate about the "welfare crisis". While the term welfare is most commonly associated with the cash Public Assistance programs, the welfare system, consists of a plethora of programs, many of which provide benefits in the form of specific goods and services. These "in-kind" programs like low-income housing, medicaid and food stamps, have grows ăramatically since the mid-1960's. Table I charts the increases in expenditures for four of the most rapidly expanding public transfer programs and reveals that the rate of growth in medicaid and food stamps has far exceeded that of Aid for Families with Dependent Children (AFDC), the most popular target of public criticism. Table I also indicates how rapidly small-scale experimental programs, like food stamps, c-.. come to command a significant share of the public budget. Table II reveals that by Fiscal Year (FY) 1973, the budget for needs-tested transfer programs was $\$ 30.7$ billion and demonstrates that in-kind transfer programs had ballooned so ra- 
TABLE I

EXPENDITURES IN PUBLIC NEEDS-TESTED INCOME TRANSFER PROGRAMS, SELECTED YEARS 1 (expenditures in thousands of dollars)

\begin{tabular}{|c|c|c|c|c|c|}
\hline PROGRAM & 1966 & $\begin{array}{l}\text { FISC } \\
1969 \\
\end{array}$ & AR $\quad 1972$ & 1973 & $\begin{array}{c}\text { PERCENT INCREASE } \\
1966-1973 \\
\end{array}$ \\
\hline Food stamps & 70,500 & 251,000 & $1,916,900$ & $2,606,600$ & 3597 \\
\hline Public Housing & 256,673 & 391,611 & 889,114 & $1,101,810$ & 329 \\
\hline Medicaid & 369,600 & $4,165,765$ & $8,137,653$ & $9,110,552$ & 2365 \\
\hline $\begin{array}{l}\text { AFDC cash payrents } \\
\text { to beneficiaries }\end{array}$ & $1,735,000$ & $3,091,803$ & $6,553,599$ & $6,954,554$ & 301 \\
\hline
\end{tabular}

${ }^{1}$ Derived from The Budget of the U.S. Government, Appendix, F.Y. 1968, pp. 133, 488, and 523; F.Y. 1971, pp. 146, 437, and 482; FY 1974, pp. 208, 442, and 499; FY 1975, pp. 203-205, 440-442, 494, and 808, (Washington, D.C.: U.S. Government Printing Office, 1967, 1970, 1973, and 1974). Includes federal, state and local expenditures. 
TABLE II

EXPENDITURES AND PARTICIPATION IN PUBLIC NEEDS-TESTED INCOME TRANSFER PROGRAMS, F. Y. $1973^{I}$ (expenditures in thousands of dollars)

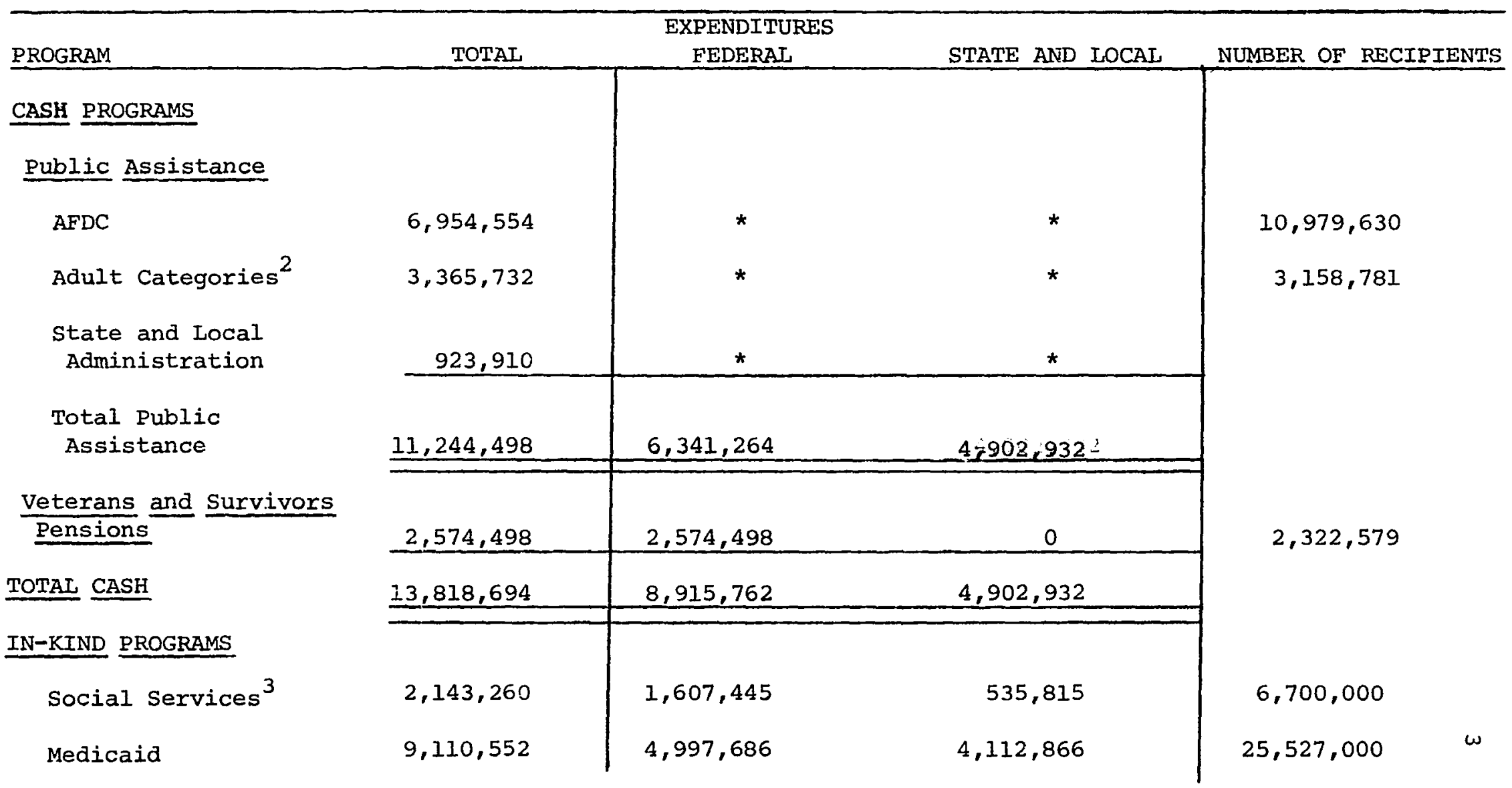


TABLE II

(continued)

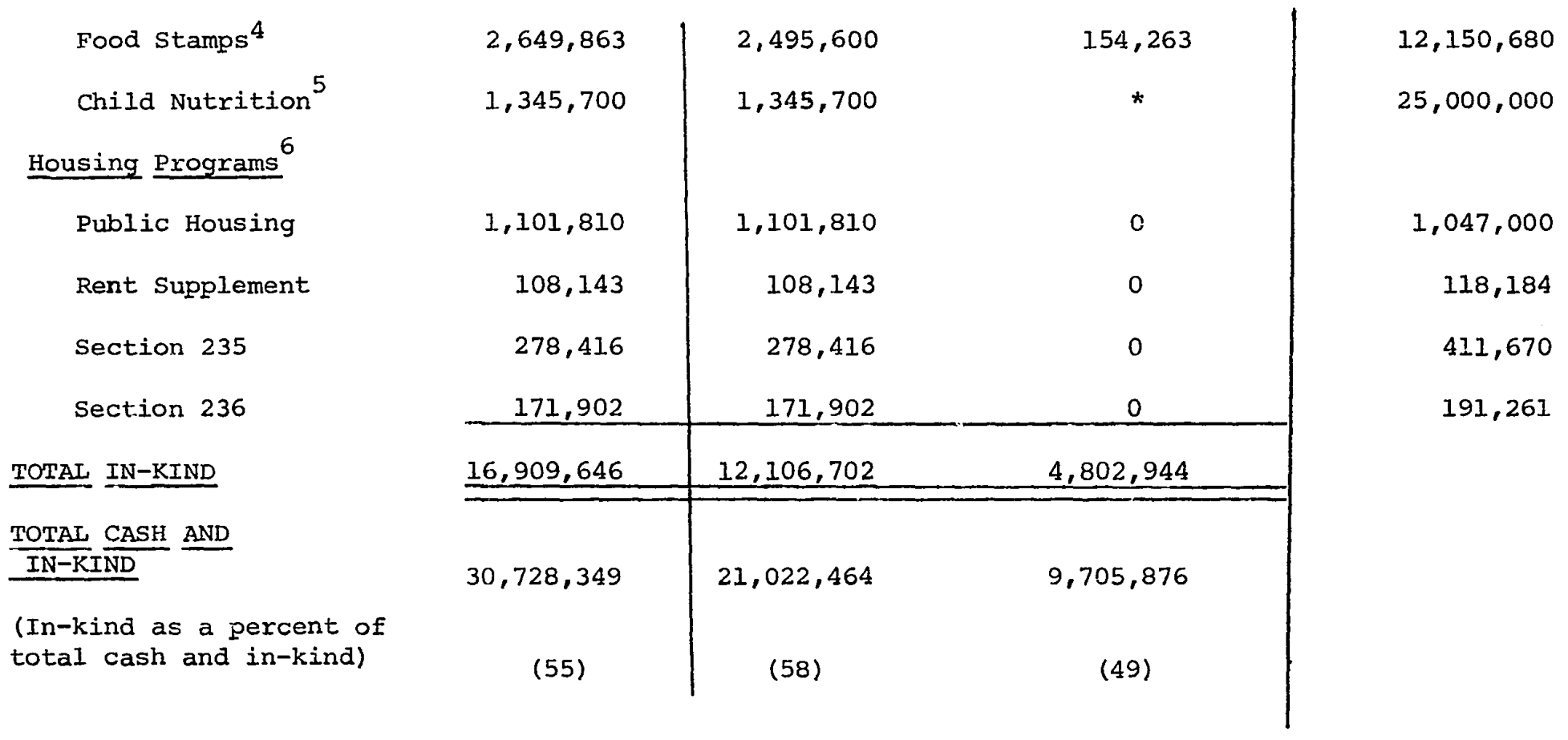

$1_{\text {Derived from The Budget }}$ of the U S. Government, Appendix, FY 1975, (Washington, D.C.: U.S. Government Printing office, 1974$), \frac{p p .}{203-20} \frac{0}{5,440-442}, \frac{\text { Appendix }}{292, \text { and }} 808$.

Includes Aid to the Partially and Totally Disabled (APTD), Aid to the Blind (AB), Old Age Assistance $O A A$, and Emergency Assistance.

$3_{F}$ rederal and state and local shares are e.stimated based on the required $75 / 25$ match. 
TABLE II

(Continued)

4

Estimate for state and local expenditures was obtained by projecting from oregon data.

${ }^{5}$ Includes School Lunch, Schoo?. Breakfast and Special Milk programs.

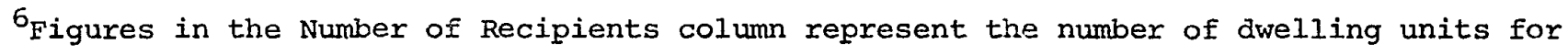
housing programs.

*Unavailable. 
pidly that by FY 1973 they dominated cash transfers in the welfare budget.

Criticism of welfare programs have not been confined to the acceleration of costs. Fqually crisial are judgements that the welfare system is $i_{i n} d$ state of administrative chaos and that a perverse structure of incentives had inaāivertently been created. The dynamics of the welfare crisis were clearly outlined in hearings regarding the administration of welfare before the Subcomittee on Fiscal Policy of the Joint Economic Committee in the Spring of 1972. Witnesses ranged from John G. Veneman, Under Secretary of HEW, to other prominent federal officials, to state welfare administrators, to local welfare supervisors, to caseworkers in Atlanta, New York and Detroit. Those testifying were unanimous in their condemnation of the present system; not a single witness suggested that welfare programs were functioning adequately. Most would agree with Veneman that the problems with welfare were so fundamental that minor modifications would fail to solve them. Veneman informed the committee that

Many, if not most, of the problems your investigation will uncover are the direct result of a failing system with overwhelming structural weaknesses that cannot be solved under existing law. 1

1 U.S. Congress, Joint Economic Committee, Subcommittee on Fiscal Policy, Problems in Administration of Public Welfare Programs: Hearings Before the Subcommittee on Fiscal Rolicy, (Washington, D.C.: U.S. Government Printing Office, 1972), p. 67. 
ADMINISTRATIVE ISSUES

Diffusion of Responsibility and Variations in Standards

Responsibility for public welfare programs is diffused horizontally within a single level of. government and vertically between levels of government in the federal system. Local welfare agencies are compelled to administer a multiplicity of programs whose eligibility criteria and operating procedures are uncoordinated at best and have conflicting objectives and requirements at worst. Programs targeted for the poor fall under the jurisdiction of the Department of Labor (manpower programs), the Department of Agriculture (food stamps and child nutrition programs), the Department of Health, Education, and Welfare (public assistance and medicaid), and the Department of Housing and Urban Development (housing programs). Each of these federal departments have their bureaucratic arms at the state and local levels. To further complicate matters, welfare legislation is fed through a variety of Congressional committees. In the House, welfare legislation may land in Ways and Means, Veterans Affairs, Agriculture, Education.and Labor, or Banking and Currency. The Senate counterparts are Finance, Veterans Affairs, Labor and Public Welfare, Agriculture and Forestry, and Banking, Housing and Urban Affairs.

State governments have a similar array of welfare bureaucracies and legislative committees. While some transfer programs like food

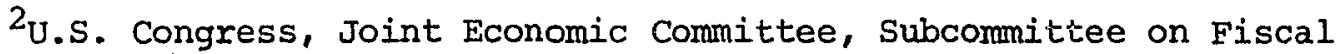
Policy, Studies in Public Welfare, Paper No. 2, Handbook of Public Income Transfer Programs, (washington, D.C.: U.S. Government Printing Office, 1972), pp. 5-7. 
stamps have national standards, many like AFDC and medicaid relegate benefit and eligibility determination to the states. This has resulted in a very substantial interstate variation in the benefits available to recipients with essentially the same income and family characteristics. For example, in January, 1974, the average monthly AFDC payment per recipient ranged from $\$ 14.36$ in Mississippi to $\$ 91.83$ in Wisconsin. 3 on the local level, welfare is administered by 1,153 autonomous units. ${ }^{4}$ In sum, welfare legislation originates at many distinct points in the federal system. There are few incentives for the responsible agencies and committees to coordinate their efforts. As a result of the system as a whole has conflicting parts which create administrative headaches and inequities in the treatment of recipients. Local officials and federal administrators all complain that they lack sufficient power to bring order to the system. Those responsjble for administering welfare programs on the locallevel complain that federal regulations exhibit a lack of understanding of local conditions and that the complexity and conflicts inherent in the system stem from the separation of responsibility for day-to-day program operations from rulemaking. Local officials testified that many programs are virtually unadministerable in their present form. Federal officials

3 U.S. Congress, House of Representatives, subcomittee of the Committee on Appropriations, Departments of Labox and Health, Education and Welfare Appropriations for 1975 , Part 6 , Department of Health, Education, and Welfare, (Washington, D.C.: U.S. Government Printing Office, 1974), pp. 25-26.

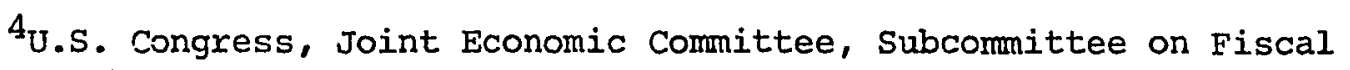
Policy, Probleins ..., op. cit., p. 68. 
in turn, bemoan their lack of control over local agencies and claim that they leave few realistic sanctions to employ against recalcitrant local administrators. 5

\section{Complexity, Error and Fraud}

Sharon Galm, staff legal counsel for the Subcommittee on Fiscal Policy, after conducting an extensive analysis of welfare administration, sumarized,"Because of the nature of present eligibility and budget criteria, accurate application procedures are not feasible, and feasible procedures are not accurate." 6 The extreme complexity of eligibility and payment formulas imposes a high cost on both caseworkers and applicants. While Galm was primarily concerned with the functioning of the AFDC program, many in-kind transfer programs are also characterized by extremely complex formulas.

Complexity stems from several sources. Some is a function of the diffusion of responsibility for rulemaking between and within levels of government as discussed above. Some complexity is the product of the determination to keep welfare costs down by screening the "unworthy" poor out of the system. The categorical aid system istablished in the Public Assistance programs testifies to the salience of recipient characteristics other than income. For example, the AFDC program

\section{Ibid.}

${ }^{6}$ Sharon Galm, Studies in Public Welfare, Paper No. 5 (Part 1), Issues in Welfare Administration: Welfare an Administrative Nightmare, prepared for the U.S. Congress, Joint Economic Committee, subcomittee on Fiscal. Policy, (Washington, D.C.: U.S. Government Printing Office, 1972), p.1. 
is aimed at poor mothers with dependent children, not at the equally poor intact family or single individual.

Another, quite different impulse has also contributed to complexity. This is the effort to humanize the system by taking into account the individual circumstances of applicants. Most welfare programs reflect an effort to consider individual cases on their own merits in the adoption of involved income and assets determination procedures. However, the specific procedures adopted are not uniform across programs: legitimate "hardship" deductions from gross income under Food stamps may not be allowed under AFDC or public housing and vice versa. Handler and Hollingsworth note that the proliferation of rules intended to personalize the system leaves the caseworker with considerable discretion in the determination as to precisely who is eligible and what they will receive. While this discretion may as frequently benefit the client as harm him, it does mitigate against the equal treatment of equals. Inevitable inequities creep into the system. 7

The plethora of rules and regulations increases administrative costs as the time required per case is a function of complexity.

Local welfare agencies are supposed to follow directives which may fill a bookshelf 4 feet wide ... To process one welfare applicant in Atlanta rergures as many as 27 different forms; Detroit food stamp

7 Joel. F. Handlex and Ellen Jane Hollingsworth, The "Deserving Poor": A study of Welfare Administration, Institute for Research on Poverty Monograph Series, (Chicago: Markham Publishing Co., 1971). 
workers are responsible for using about 40 different

forms. 8

Efforts to streamline procedures have been unsuccessful because of the failure of all the relevant parties to cooperate.

The basic structure of the system contributes to a high-rate of error in the determination of eligibility and payment levels. That exrors abound in the AFDC program has been verified by GAO and HEW investigations. In April-September, 1973, nationally, errors were in $41.1 \%$ of AFDC cases. Of these, 10.28 of the cases involved payments to ineligibles, 22.88 concerned overpayments and 8.18 involved underpayments. The cost of these errors amounted to $14.6 \%$ of total program payments. 9 It is probably that large administrative errors are also characteristic of other complex transfer programs, but the principle target of investigation to date has been AFDC.

In contrast to administrative error, a very small percentage of cases are investigated for fraud and an even smaller number are referred to law enforcement agencies. The amount of undetected fraud is an unknown quantity as welfare agencies are generaliy too overburdened to pursue more than a few token cases. Many caseworkers testified before the Subcommittee on Fiscal Policy that they felt severly constrained in dealing with claims that they suspected to be fraudulert. A combi-

8 Sharon Galm, op. cit., p. 5 .

${ }^{9}$ U.S. Congress, House of Representatives, Subcomittee of the Comittee on Appropriations, op. cit., p. 29. 
nation of Supreme court rulings and the increased militancy of welfare recipients has made it necessary to undertake expensive and lengthy litigation to prove fraud. Even if fraud is proven, the probability of collecting from households with few financial resources is small. Most potential fraud cases are buried because caseworkers have other priorities and officials have concluded that there is little to be gained by pressing charges. 10

\section{Staff Shortages and High Turnover}

Public welfare agencies are chronically understaffed and suffer from high rates of turnover. Heavy caseloads are common and frequent schedule updates add to the burdens of welfare workers. Increases in benefit and/or eligibility levels, which are made periodically to keep pace with the cost of living, require reviews of the entire caseload. The need for such reviews has accelerated recently as benefit levels have been altered more frequently as the rate of inflation has increased. Rule changes unrelated to benefit levels or definitions of the eligible population also appear habitually. In many cases, these reflect deep Congressional dissatisfaction with the operation of the welfare system which has spurred tinkering with its structure in an effort to make it work. Another source of administrative burden is the irregular income characteristic of the welfare population. Changes in income require recalculations of benefits just as do changes in

${ }^{10}$ U.S. Congress, Joint Economic Committee, Subcommittee on Fiscal Policy, Problems ..., op. cit., pp. 191-193. 
benefit schedules or other rules. ${ }^{11}$

The workers being asked to assume this administrative load are typically young, inexperienced, and poorly trained. Most caseworkers are young college graduates who do not intend to remain in welfare work for very long. Training is minimal and primarily of the on-thejob variety. 12 Considexing the complexity of what needs to be learned and retraining of all staff required by changes in policies and procedures it is not surprising that there is a high rate of administrative error.

\section{PERVERSE INCENTIVES}

Barriers to the Participation of the Eligible: High Participation and Transaction Costs

In addition to the purposeful discrimination among the poor inherent in the categorical aid system, the welfare structure inadvertently and inequitably favors the mobile, aggressive and persistent eligible over the immobile, the meek and the tired, but equally eligible poor. The testimony before the subcommittee on Fiscal Policy of Bobbie Poussaint, Director, Community Social Services Program, Department of Social Services, New York City Human Resources Administration enumerates the high participation costs imposed on some intended beneficiaries.

11 Sharon Galm, op. cit.

12 Ibid., pp. $32-34$. Joel F. Handler and Ellen Jane Hollingsworth, op. cit., pp. 49-51. 
We found that it requires a high degree of sophistication and courage on the part of recipients and consumers to enable them to obtain benefits to which they are entitled.

Many such persons have difficulty in even obtaining information regarding which benefits are available and what they must do in order to obtain them. Many have extreme difficulty in negotiating the system after learning about available benefits.

For example, many of the aged poor find it impossible to take advantage of the food stamp program because of the extensive and expensive traveling involved in order to become eligible for this program. Many persons have difficulty utilizing medical services under Medicaid for a variety of reasons, primarily, due to the location of vendors and the difficulties encountered in yetting to these vendors.

Many heads of households, particularly one-parent families encounter a lack of symchronized effort between child care programs, vocatiznal training programs, and the income maintenance programs. Frequently, they are interested in training and employment; however they become discouraged when either of the aforementioned components becomes dysfunctional. The result is a loss of interest and increased hostility. 13

These high participation costs help explain why many welfare programs, with no legal limit to the number of recipients, enroll only a fraction of those eligible.

Work Disincentives: High Marginal Tax Rates and Notches

While Congress has consistently voiced strong support for work incentives for welfare recipients, the actual impact of some individual programs and many program packages is precisely the opposite of Congressional intent. Policies for individual programs are typically considered in isolation from other programs serving the same population. This failure to simultaneously consider groups of programs has

13 U.S. Congress, Joint Economic Committee, Subcommittee on Fiscal Policy, Problems ..., op:cit., pp. 143-144. 
led to some bizarre results. For example, increases in Social security benefits may lead to an income loss rather than a gain for intended beneficiaries when such increases lead to reductions in benefits under other programs such as food stamps and/or medicaid.

Lerman shows that marginal tax rates for individual programs typically range from 24-35\%; each extra dollax earned is worth only 65-76 cents to the recipient because of benefit reductions associated with earnings increases.14 Hausman indicates that combinations of programs have much higher rates. An AFDC motiler of three benefiting from food subsidies, medicaid and public housing faces a marginal tax rate of up to $76 \%$ on earnings; each additional dollar is worth only 24 cents. $^{15}$ storey notes that a household receiving AFDC, food stamps, and public housing faces a marginal tax rate of 858 on earn16

ings. Aaron concurs that marginal tax rates in excess of $67 \%$ are common for program combinations. 17

14 Robert I. Lerman, "Incentive Effects in Public Income Transfer Programs, "Studies in Public Welfare, Paper No. 4, Income Transfer Programs: How They Tax the Poor, prepared for the U.S. Congress, Joint Economic comittee, Subcomittee on Fiscal Policy, (Washington, D.C.: U.S. Government Printing Office, 1972), pp. 1-78.

15 Leonard J. Hausman, "Cumulative Tax Rates in Alternative Income Maintenance Systems," Ibid., pp. 111, 113.

${ }^{16}$ James R. Storey, Studies in Public Welfare, Paper No. 1, Public Income Transfer Programs: The Incidence of Multiple Benefits and the Issues Raised by their Receipt, prepared for the U.S. Congress, Joint Economic Committee, Subcomnittee on Fiscal Policy, (Washington, D.C.: U.S. Government Printing Office, 1972), p. 8.

17 Henry J. Aaron, Why is Welfare so Härd to Reform?, (Washington, D.C.: The Brookings Institution, 1973), pp. 33-35. 
At some earnings levels the marginal rate of taxation exceeds $100 \%$ and a "notch" occurs. A notch is a point at which the income of a household is actually reduced by increases in earnings because losses in program benefits are greater than increments in earnings. Notches are common when eligibility for one program is linked to another or when program benefits fail to vary with income once eligibility has been ascertained. For example, a one dollar increase in earnings may make a household inelgible for medicaid which may be worth $\$ 1000$ in benefits. In this case, the family loses $\$ 999$ as a result of a small improvement in earnings. Or households which become ineligible for AFDC may suddenly lose benefits from a range of other programs if eligibility for the non-AFDC programs is contingent upon eligiblity for AFDC.

While rational analysis of the above tax structure might lead many a program participant to avoid work, Aaron notes that the complexity of the systern may inhibit the preception of the high tax rates which prevail. "A system with high, but obscure, marginal tax rates may deter work less than a system with lower, but clearly visible, tax rates." 18 In addition, the link between the perception of various rates and actual behavior is unclear. However, it may be concluded that Congressional attention to individual programs rather than to the combined impact of program packages has created a formal structure which does not strongly reward work effort. This outcome is in direct contradic-

18 Ibid., pp. 37-38. 
tion to the publically expressed priorities of most Congressmen.

Work Disincentives: High Potential Benefit Levels

Benefit levels under the present system may exceed full-time earnings at the minimum wage. While the typical welfare recipient is probably not so fortunate, individuals in states with generous benefits or individuals able to benefit from several programs may enjoy incomes well above those of many workers. A staff study for the subcommittee on Fiscal Policy analyzed the benefits available from combinations of welfare programs in 100 counties for different family ty-pes. These benefit combinations were compared with earnings from full-time employment at the ninimum and median wage levels in those counties. Table III depicts the results of the study for a maleheaded family of four in Nultnomah County, Oregon (Portland), in Suffolk County, Massachusetts (Boston), a high benefit county, and in Bolivar County, Mississippi, a low benefit rural county. Table III demonstrates that welfare benefits in high benefit counties like Multnomah and Suffolk may exceed earnings at the minimum wage, and may even exceed the median county income for males in suffolk County. In the 100 counties surveyed, only three southern counties had benefit schedules which unambiguously rewarded work effort across all family types. Table III also illustrates the large interstate variations in the treatment of households of identical income and structure. 
TABLE III

ANNUAL BENEFITS FOR HOUSEHOID WITH EMPLOYABIE HEAD, BY WORK STATUS (AS OF JULY, 1972), HUSBAND, WIFE AND TWO CHILDREN, SELFCTED COUNTIES ${ }^{2}$

\begin{tabular}{lccccc} 
& $(1)$ & $(2)$ & $(3)$ & $(4)$ & $(5)$ \\
COUNTY AND WORK & & UNEMP. & TOTAI & GENERAI & NET CASH \\
STATUS OF HEAD & EARNINGS & INSUR. (UI) & TAXES & AFDC-U & ASSIST. \\
\hline
\end{tabular}

Multnomah, Oregon

$\begin{array}{lr}\text { No work, U.I. benefits } & 0 \\ \text { No work or U.I. benefits } & 0 \\ \text { Worls } 40 \text { hrs. @ } \$ 2.00 & 4000 \\ \text { Earns male median income } & 7968\end{array}$

1092

0

o

Suffolk, Massachusetts

No work, U.I. benefits

No work or U.I. benefits

Works 40 hrs. @ $\$ 2.00$

0

Earns male median income

6946

Bolivar, Mississippi

No work, U.I. benefits

No work or U.I. benefits

Works 40 hrs. @ $\$ 2.00$

0
0

Earns male median income 3643

0
0
208
1168

1458
2915
0
0

366
0
0
0

2916

2916

2792

6800

$24 \mathrm{CR}^{2} \quad 171$

$24 \mathrm{CK}^{2} \quad 4075$

184

869

0

721

0

0

4099

3816

6077

$\begin{array}{rr}832 & 0 \\ 0 & 0 \\ 0 & 208 \\ 0 & 189\end{array}$

832

3792 
TABIE III

(continued)

\begin{tabular}{|c|c|c|c|c|c|}
\hline (7) & (8) & (9) & (10) & (11) & (12) \\
\hline $\begin{array}{l}\text { FOOD STAMPS OR } \\
\text { COMMODITIES } \\
\end{array}$ & $\begin{array}{l}\text { SCHOOL } \\
\text { IUNCHES }\end{array}$ & $\begin{array}{l}\text { WORK } \\
\text { EXPENSES } \\
\end{array}$ & $\begin{array}{c}\text { NET CASH, FOOD AND } \\
\text { PUBLIC HOUSING }\end{array}$ & $\begin{array}{l}\text { DISCRETIONARY } \\
\text { INCOME (10-9) }\end{array}$ & $\begin{array}{l}\text { GROSS TAXABIE } \\
\text { EOUIVALENT }\end{array}$ \\
\hline 900 & 63 & 0 & 5057 & 5057 & $556 Z$ \\
\hline 900 & 6.3 & 0 & $505: 7$ & 5057 & 5561 \\
\hline 708 & 63 & 684 & 5604 & 4920 & 5388 \\
\hline 0 & 0 & 684 & 7114 & 6430 & 7555 \\
\hline 595 & 54 & 0 & 5701 & 5701 & 6345 \\
\hline 595 & 54 & 0 & 5972 & 5972 & 6692 \\
\hline 595 & 54 & 684 & 5953 & 5269 & 5799 \\
\hline 0 & 0 & 684 & 6077 & 5393 & 61.31 \\
\hline 1284 & 54 & 0 & 2170 & 2170 & 2304 \\
\hline 1344 & 54 & 0 & 1398 & 1398 & 1484 \\
\hline 492 & 54 & 684 & 4338 & 3654 & $388 I$ \\
\hline 636 & 54 & 584 & 4144 & 3460 & 3674 \\
\hline
\end{tabular}

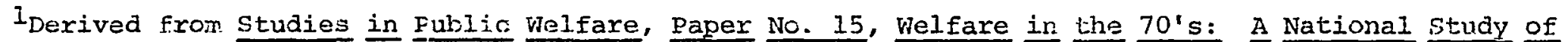
Benefits Available in 100 Local Areas, A staff study for the U.S. Congress, Joint Economic Comnittee, Subcommittee on Fiscal Policy, (Washingtor, D.C.: U.S. Government Printing office, 1974), Tajles 43,53, and 76.

$z_{C R}$ indicates a tay credit. 
It should be noted that Table III indicates the hypothetical benefits available in different local areas, rather than the actual benefit payments. A crucial question is the extent to which multiple program participation prevails among the eligible. In 1973, the subcommittee on Fiscal Policy conducted a study of the actual incidence of welfare benefits in six of the sites which the Census Bureau has designated as "low income." of the 1,758 households surveyed, 40\% received no benefits, $60 z$ received benefits from 1 or more programs, $40 \%$ received benefits from 2 or more programs, $26 \%$ received benefits from 3 or more programs, 178 received benefits from 4 or more programs, 118 received benefits from 5 or more programs, and $7 z$ received benefits from 6 or more programs. 19

While the nationwide incidence of actual benefits received may not be generalized from this sample, the results of the subcomittee's study suggest that few households receive all of the benefits to which they are entitled. The potentially high benefit levels shown for Multnomah and Suffolk Counties in Table III are a result of the cumulative effects of six programs. In the low income areas studied by the subcommittee, only $7 \%$ of those sampled were actually receiving this large number of transfers. In sum, while potential benefits in some states are very high, actual benefits are not, on the average. Two factors are undoubtedly important in explaining why the eligible fail

${ }^{19}$ Studies in Public Welfare, Additional Material for Paper No. 6: How Public Welfare Benefits are Distributed in Low-Income Areas, $A$ Staff Study for the U.S. Congress, Joint Economic Conmittee, Subcommittee on Fiscal Policy, (Washington, D.C.: U.S. Government Printing Office, 1973), p. 95. 
to participate in particular programs. One is that the supply of some public transfers like public housing is severely limited. Other factors, discussed above, are the high information and transaction costs imposed on the eligible by complex, uncoordinated programs.

\section{Family Break-Up}

The economic incentive for a family to break-up varies with family size, family earnings, and the number and structure of welfare benefits available in particular local areas. Family splitting incentives are especially marked in states where AFDC payments are restricted to female-headed households. While about $50 \%$ of the states permit cash payments to families with unemployed male heads, Public Assistance benefits are unavailable to households headed by employed males. Thus the "working poor" intact family is excluded from cash benefit programs, although such households are eligible for many inkind programs. 20 As is the case with the work issue, the overt objectives of public policy are diametrically opposed to the incentives created by the actual structure of programs.

\section{EXPLANATION FOR CHAOS? WELFARE POLITICS}

While there is widespread agreement on the desirability of welfare reform, consensus disintegrates when particular proposals for

${ }^{20}$ Studies in Public Welfare, Paper No. 15, Welfare in the 70 's A National Study of Benefits Available in 100 Local Areas, A staff study for the U.S. Congress, Joint Economic Committee, Subcommittee on Fiscal Policy, (Washington, D.C.: U.S. Government Printing Office, 1974), p. 39. 
change are introduced. In a lengthy analysis of the failure on the Nixon Administration's proposed Family Assistance Plan, Moynihan discusses the quite opposite attitudes of those who are equally appalled by the existing system. While some denounce the current system as ungenerous and demeaning to recipients, others find it outrageously expensive and "soft" on the poor. Those generally labeled "conservative" demand work requirements, fraud investigations, tough eligibility tests, and modest benefits. "Liberals" request higher benefit levels, liberalized eligibility requirements, eligibility determination by self-declaration rather than investigation, respect for the privacy of program participants, and flexible work-requirements, if any.

This range of opinion is reflected in Congress where substantive compromises are essential to avoid paralysis. The process of negotiation between parties in such fundamental disagreenent leads to programs which are flawed from their inception. The blurring of objectives and the contradictory provisions required to obtain consensus create enumerable administrative difficulties. Once begun, programs develop their own momentum and are rarely subject to rigorous evaluation. Pressure to maintain existing benefits are very strong from the "public" attached to on-going programs. A program's "public" includes not only its direct beneficiaries, but its bureaucracy and sym-

${ }^{21}$ Daniel P. Moynihan, The Politics of a Guaranteed Income: The Nixon Administration and the Family Assistance Plan, (New York: Vintage Books, 1973). 
pathetic pressure groups as well. David A. Stockman, who is Executive Director of the Republican Conference in the U.S. House of Representatives, contends that Congressmen become coopted by the programs they are ostensibly charged with evaluating. The political advantages of having benefits to distribute "back home" transform" Congressmen into lobbyists for ever greater social welfare budgets. Even Congressmen initially opposed to a particular program, tend to scramble for benefits for their districts and encourage program expansion once the program is established. 22 In sum, the political environment of welfare inhibits the rationalization of public transfer programs despite the strong consensus that exists that major reform is essential.

22 David A. Stockman, "The Social Pork Barrel," The Public Interest, XXXIX, (Spring, 1975), pp. 3-30. 
CHAPTER II

WELFARE THEORY AND THE IMPIICATIONS OF UTILITY INTERDEPENDENCE

\section{Introduction}

The political and administrative pressures mitigating against the equitable and efficient operation of the weifare system have been detailed in Chapter I. This chapter will outline some of the major controversial theoretical issues regarding redistribution that have plagued welfare economists. Standards for measuring the efficacy of public policies with redistributive objectives have generally been phrased in terms of elusive abstractions such as "equity", "the public interest," and "social justice" which are rarely operationalized. The rigorous evaluation of public welfare programs has lagged behind the evaluation of other governmental endeavors, in part, because of the uncertainty over appropriate objectives in the area of redistribution. How much should be transferred to whom, from whom, under what conditions, and in what form, are the fundamental questions that welfare theory must address. Welfare theory has not provided unambiguous normative responses to these questions, nor has it offered a well-developed positive theory to explain the observed amount and form of redistribution. 1

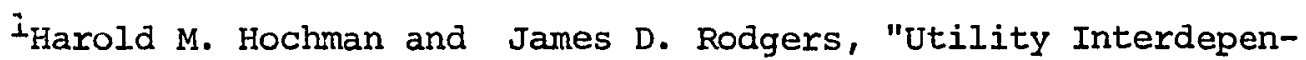
dence and Income Transfers through Charity," in Kenneth E. Boulding, Martin Pfaff and Anita Pfaff, editors, Transfers in an Urbanized Economy: Theories and Effects of the Grants Economy, (Belmont: Wadsworth Publishing Co., Inc., 1973), Pp. 63-77. 
FROM THE SOCIAL WELFARE FUNCTION TO UTILITY INTERDEPENDENCE

Economists have traditionally viewed allocation and distribution as conceptually distinct functions of the public sector. 2 Allocational decisions were characterized as fundamentally technical, while distributional choices were seen as normative. Thus efficiercy and equity determinations were divorced from one another. The widely accepted benchmark for measuring the efficiency of allocational options is the Paretian rule. A change in economic conditions is judged "Pareto Optimal" (efficientlgood) if, and only if, the welfare of some individual is improved without the welfare of anyone else being diminished. Despite the efforts to separate efficiency criteria from ethical issues, the Paretian rule is not value-free. It posits that everyone count and that, therefore, no one ought to be made worse off. Other value premises would lead to other rules. The efficiency/equity dichotomy has also been weakened by the growing acknowledgment that public policies which ostensibly have only allocational repercussions frequently alter the distribution of resources between individuals or groups as well.

Transfers which redistribute resources from some members of society to others have traditionally been viewed as confiscatory; one man's gain necessitated another man's loss. The utility functions of individuals were specified as independent of one another in line with

${ }^{2}$ Richard A. Musgrave and Peggy B. Musgrave; Public Finance in Theory and Practice, (New York: Mc Graw-Hill, Inc., 1973), Pp. 6-14. 
the classical characterjation of "economic man" as selfish in his motivation and behavior. While the self-interested actions of individuals in the market were presumed to have socially beneficial results, the utility of individual A did not enter into the utility function of individual $\mathrm{B}$ or vice versa. Therefore, transfers could not be fitted into the Paretian schema since the donor would presumably be made "worse off" by his donation. To explain transfers, and to guide redistributional decisions, welfare economists resorted to a social welfare function. The social welfare function specifies the weights which should be given to the welfare derived by various individuals -- it identifies society's "winners" and "losers". As such, the social welfare function demands interpersonal comparisons of utility and requires a collective rather than an individualistic conceptialization of society. ${ }^{3}$ Determination of the "best" social welfare function remains beyond the boundaries of micro-economic theory which is based on consumer sovereignty. Selfinterested trade in the competitive market is presumed to benefit all; the specification of trade-offs between the welfare of individuals is alien to this tradition and cannot satisfy the Paretian criterion. As a result, most economists have treated the social welfare function as exogenous in their analyses of efficiency in the provision of public goods. The specification of the social welfare function was viewed as essentially a philosophical or political matter rather than an econo-

3 Francis m. Bator, "The Simple Analytics of Welfare Maximization," The American Economic Review, XLVII, (March, 1957), pp. 22-59. 
mic issue.

Some elegant models of voting behavior and political parties have been developed by Arrow, Downs, and Buchanan and Tullock in an effort to solve the problem of aggregating individual preferences into a social welfare function. 4 However, the opportunities for strategic behavior (the masking of preferences), the costs of political participation and the ambiguity or intransitivity of results in large group nulti-issue representative political systems have precluded a definitive solution to the problem of moving from the individual to the collective. In the end, political analysts have generally resorted to a logrolling model to describe the public policy-making process in formally democratic nations. While conflicts between individuals or groups may make it impossible to reach consensus on specific issues, considered in isolation, vote trading permits agreenent on packages of issues. Vote trading allows variations in the intensity of preferences on particular issues to be reflected in the political process. However, precisely what is maximized through the political system remains unsleax. The search for more effective ways of aggregating demand continues.

Welfare theory foundered for many years in an effort to reconcile the collectivist requirements of a social welfare function with the

4kenneth J. Arrow, Social Cheice and Individual Values, 2nd ed., (New Haven: Yale University Press, 1963). James M. Buchanan and Gordon Tullock, The Calculus of Consent, (Ann Axbor: The University of Michigan Press,..1963). Anthony Downs, An Economic Theory of Democracy, (New York: Harper and Row, 1957). 
individualistic basis of the rest of economic theory. Hochman and Rodgers made a major effort to break the bottleneck. In exploring the possibilities of utility interdependence, they attempted to integrate redistribution into micro-theory and erase the divisions between allocation and distribution, efficiency and equity. ${ }^{5}$ They demonstrate how the Paretian schema may require redistribution if individual utility functions are benevolently interdependent. In contrast to the Robin Hood view of transfers which has dominated economics, Hochman and Rodgers indicate that redistribution may not be a zero-sum game. In a two-person economy, redistribution may improve everyone's position if two individuals, wealthy Mutt and indigent Jeff (to use the authors' examples) derive satisfaction from both their own income and each others' income. In other words,

$$
\begin{aligned}
& \text { (1) } U_{M}=f_{M}\left(Y_{M^{\prime}} Y_{J}\right) \\
& \text { (2) } U_{J}=f_{J}\left(Y_{M}, Y_{J}\right)
\end{aligned}
$$

where $U_{M}$ and $Y_{M}$ are Mutt's utility index and income, and $U_{J}$ and $y_{J}$ are the corresponding values for Jeff. In this model the income of Mutt is treated as an externality for Jeff and vice versa. As such, the specification of trade-offs between the welfare of individuals (the social welfare function) becomes unnecessary. Mutt will voluntarily agree to transfer to Jeff up to the point where the marginal increase in Mutt's utility derived from an increase in Jeff's income

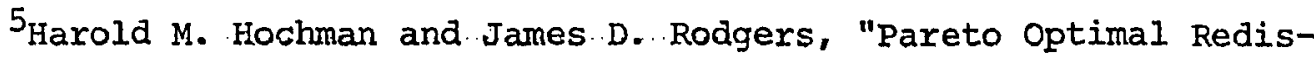
tribution," The American Economic Review, LIX, (September, 1969), pp. 542-5.57. 
equals the marginal increase in Mutt's utility derived from increases in his own income.

As with other social goods, when consideration turns from the two-person to the n-person case, government action is required to circumvent the "free rider" problem and compel transfers. Presumably Mutt's utility would increase if Jeff's transfer originated in some other wealthy Mutt's pocket, rathex than in his own. Therefore, it would be to Mutt's advantage to conceal his preferences for transfers and to "free ride." In addition, if there are many poor Jeffs, Mutt will undoubtedly recognize the futility of significantly improving the welfare of the poox through his contribution alone. Thus the Mutts would rationally elect to compel themselves to make redistributive transfers through their government.

Hochman and Rodgers' assumption of benevolent utility interdependerce has some empirical support from the existence of private charity (about $\$ 12$ billion per year).$^{6}$ It is reasonable to assume that there is a declining marginal utility of income and that at some high consumpition level, increments in another's income may be willingly substituted for increments in one's own consumption. In an inter-urban investigation, Hochman and Rodgers found significant positive correlations between charitable contributions in a city with the city's income and the city's ircome dispersłon:"7

6Richard Musgraye, "Pareto Optimal Redistribution: Comnent," The American Economic Revien, IX. (December, 1970), pp. 991-993.

7 Harold M. Hochman and James D. Rodgers, "Utility Interdependence and Income Transfers through Charity," op. cit. 
GOODS-SPECIFIC UTILITY INTERDEPENDENCE: THE CASE OF MERIT GOODS

Fochman and Rodgers initially considered only cash transfers, but in a later comment, they indicated that their analysis could appropriately be applied to merit goods. 8 Merit goods are public goods unlike "pure" social goods, in that they entail neither joint consumption nor exclusion difficulties. They are goods which could be provided by the market, but, if left to the market, are undersupplied or underconsumed because social benefits exceed private benefits. For example, an individual may elect not to invest in education but the society has an interest in compelling him to do so. In an effort to internalize these sorts of externalities, particular goods and services (i.e. food, education, medical care) may enter the public sector through subsidy, regulation and/or public provision.

Merit goods are something of an anomaly in economic theory, although in real life they are an extremely popular form of transfer. Musgrave notes that micro-theory based on assumptions of consumer sovereignty has a difficult time incorporating the merit good concept since the explicit purpose of a merit good is to interfere with consu9 mer choice. Economists have attempted to cope with merit goods in several ways. Merit goods" may be considered as the imposition of elite

8 Harold M. Hochman and James D. Rodgers, "Pareto Optimal Redistribution: Reply,". The American Economic Review, LX (December, 1970), pp. 997-1002.

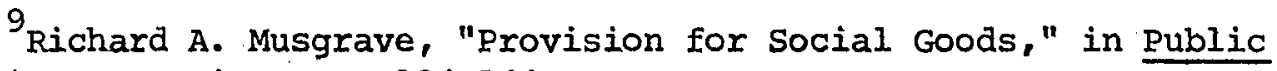
Economics, op. cit., pp. 124-144.

Richard A. Musgrave and Peggy B. Musgrave, op. cit., p. 81. 
preferences concerning the appropriate consumption patterns on the rest of the world or merit goods may be justified as a protection for the individual who may not be informed about the consequences of his actions. In these cases, individual welfare and consumption preferences are not identical. 10 In addition, certain population sub-groups such as the senile or insane may be judged incompetent to make their own decisions. These kinds of explanations for merit goods are essentially paternalistic and remain outside of micro-theory with its individualistic assumptions.

If merit goods are viewed in the context of utility interdependence, then they may be incorporated into traditional economic analysis in which the efficient allocation of goods is related to individual choice. Buchanan concludes that individualistic norms are consistent with transfers in-kind (merit goods) and that general cash transfers are not politically viable.

The evidence seems to indicate that general redistribution of purchasing power, or even general change in the relative levels of well-being is not widely desired. Instead members of the public want and express through their behavior patterns, relief for specific spending patterns.

This expression of individual preferences can be brought within the general analysis of externalities. The mere fact that some members of the community are poor does not, in and of itself, normally impose an external diseconomy on many of the remaining members. What does impose such an internal diseconomy is the way that certain persons behave when they are poor. It is not the low income of the family down the street that bothers most of us; it is the fact that the family lives in a dilapidated house and dresses its children in rags that imposes on our sensibilities. And we are willing to pay something to remove this external effect; it

10 Abram Bergson, "On Social Welfare Once More", in Essays in Normative Economics, Abram Bergson, editor, (Cambridge: The Belknap Press, 1966), pp. 51-90. 
is relevant for behavior. Ordinary citizens are probably quite unwilling to finance substantial transfers of general purchasing power to the poor in their communities. But they are probably willing to finance specific transfers, either directly as income-in-kind or indirectly in purchasing power that is earmarked for specific items of spending (vouchers).11

Buchanan's position is supported by the emphasis on in-kind transfers in public welfare programs discussed in Chapter I. Further evidence of the popularity of in-kind transfers is provided by Daly and Giertz who observe that charitable institutions receive their income primarily in cash, but redistribute it largely in the form of illiquid commodities. ${ }^{12}$ Moynihan also provides extensive documentation of the public resistance to cash income redistribution strategies. ${ }^{13}$ Subsidies of particular goods and services pose problems analagous to those of selective taxation. By altering the relative prices of goods, there are important substitution and income effects related to the restructuring of the choices confronting the consumer. An exception to the rule occurs when the price elasticity of the goods in question is equal to zero -- in this case there are no substitution effects. General cash transfers like income taxes (positive or negative) also distort choice, but the distortion is between work and leisure rather than between

11 James M. Buchanan, "What Kind of Redistribution Do We Want?" Economica, (May, 1968), pp. 189-190.

12 George Daly and Fred Giertz, "Welfare Economics and Welfare Reform," The American Economic Review, LXII, (March, 1972), p. 131.

${ }^{13}$ Daniel P. Moynihan, The Politics of a Guaranteed Income: The Nixon Administration and the Family Assistance Plan, (New York: Vintage Books, 1973). 
particular goods (except in cases where the demand for particular goods is income elasticl. In general, in the case of subsidization of a particular good or service, there is a "benefit shortfall" analogous to the "excess burden" created by specific taxation. If the public supply of a subsidized good is greater than what consumers would have purchased, given a free choice and a general subsidy, then there is a benefit shortfall. 14

Both in-kind and cash transfers may be considered in the context of utility interdependence. This interdependence may logically take several forms. Interdependence may be benevolent or malevolent; it may be related to income in general (as in the Hochman and Rodgers model) or it may be related to the consumption or non-consumption of specific goods. In addition, interdependence may be related to characteristics of both donors and recipients other than income or preferred consumption patterns.

Daly and Giertz have indicated that in a two-person economy, the following interdependent relationships may exist between a wealthy and an impoverished individual (3-6 below).$^{15}$ For the sake of continuity, Hochman and Rodger's terminology -- rich Mutt and poor Jeff -- will be used.

(3) If $\frac{\mathrm{dU}^{\mathrm{M}}}{\mathrm{dU}}>0$ and $\frac{\mathrm{du}^{\mathrm{M}}}{\mathrm{dU}}=0$

${ }^{14}$ Richard A. Musgrave and Peggy B. Musgrave, op. cit., p. 460.

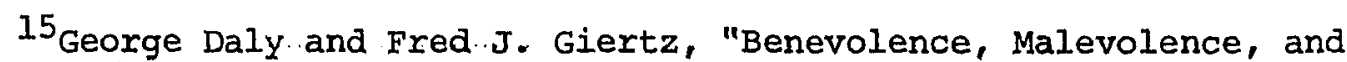
Economic Theory," Public Choice, XIII, (Fall, 1972), pp. 1-19. George Daly and Fred J. Giertz, "Welfare Economics and Welfare Reform," op. cit. 
then a "utility externality" exists. UM is Mutt's.utility function, $\mathrm{U}^{J}$ is Jeff's utilfty function, and $\mathrm{X}_{i}^{J}$ is Jeff's consurption of the ith good. In this case Jeff's utility index appears in Mutt's utility function, while Jeff's consumption of particular goods does not. This is similar to Hochman and Rodgers' model (1-2 above) except that Hochman and Rodgers assume that the relationship between Mutt and Jeff is reciprocal while Daly and Giertz specify it as one-way.

$$
\text { (4) If } \underset{d x_{i}^{J}}{\frac{d U^{M}}{J}}>0 \text { and } \frac{d U^{M}}{d U^{J}}=0
$$

then a "goods externality" exists. Mutt's utility is related to Jeff's consumption of a particular good while it is independent of Jeff's general level. of well-being. In both (3) and (4) transfers from Mutt to Jeff would be Pareto optimal, since both Mutt and Jeff would benefit from redistribution. (It is assumed that increases in Jeff's consumption of $x_{i}$ increase Jeff's utility). While (3) suggests a cash transfer, (1) implies that a transfer-in-kind may be more efficient. Whether or not a transfer-in-kind will in fact be the superior solution depends not only on the presence of a "goods externality." The efficiency of an in-kind transfer hinges on the original consumption pattern of the recipient, on the magnitude of the "goods externality", on the price and income elasticity of the good, and on the transaction costs associated with the transfer form. These issues will be discussed in detail below.

While $(1-4)$ assume benevolent interdependence, it is possible that interdependence is malevolent. Specifically, Mutt and Jeff's re- 
lationship may have the following forms.

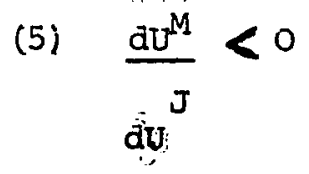

In this case, improvements in Jeff's utility lead to a decline in that of Mutt.

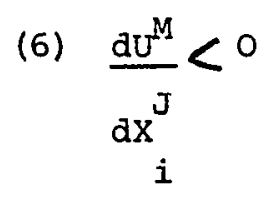

In this case, Jeff's consumption of a particular good imposes an external diseconomy on Mutt.

While the existence of private charity and public welfare programs are evidence in favor of benevolent interdependence, observations of real world behavior may also support a case for malevolent interdependence. Mutt's perception of his own well-being may hinge, in part, on his knowledge of Jeff's poverty. Income differentials are a major way of assigning status in society and one's social status is relevant to one's sense of worth. ${ }^{16}$ Malevolence may also be goods specific, as in equation (6). Mutt's enjoyment of his Mercedes may be diminished by Jeff's consumption of a similar vehicle. In addition, diseconomies related to the consumption of particular goods may involve cases other than envy; equation (6) may hold when the private consumption of particular goods (i.e. gambling, prostitution, drugs, communi-

\section{6}

Lee Rainwater, What Money Buys: Inequality and the Social Meaning of Income (New York: Basic Books, Inc., 1974). 
cable diseasesl imposes external costs on the larger society.

In a two-person economy, the relationship between Mutt and Jeff is fairly simple. Moving to an $n$-person society creates several problems in addition to the "free rider" dilemma. The willingness of the haves to transfer to the have-nots may hinge not only on the income and goods consumption patterns of the poor, but on their non-economic characteristics as well. For example, donors may support transfers to the "honest" poor while rejecting them for the "lazy" poor or for "welfare cheats". They may be willing to transfer quality education to poor whites but not to poor blacks. They may be sympathetic to the plight of the elderly, blind, or handicapped indigent, while disinterested in the struggle of a working father to support his family on low wages. In fact, the extreme complexity of our present welfare system reflects precisely such an effort to differentiate between the "deserving" and the "undeserving" poor.

THE EFFECTS OF TRANSFER MODES ON CONSUMPTION PATTERNS

olsen ${ }^{17}$ and orr $^{18}$ have both explored the relationship between transfer forms and the consumption patterns of the poor. In the case of housing, orr assumes that a "goods externality" is present -- that

17Edgar 0. Olsen, "Some Theorems in the Theory of Efficient Transfers," The Journal of Political Economy, LXXIX, (January/February,197I), pp. $166-176$.

${ }^{18}$ Larry Orr; The Welfare Economics of Housing for the Poor, Discussion Paper 33-60, (Madison: Institute for Research on Poverty, The University of Wisconsin, December, 1968). 
the donors' utility is related to the recipient's consumption of standard housing. Orr compares the consumption effects of cash transfers, housing vouchers (cash payments tied to the consumption of at least standard quality housing) and public housing (assumed to equal the lowest cost standard housing). Figure lA demonstrates the impact of various amounts and forms of transfers, assuming that the indifference map of the recipient is known and that all transfer forms entail identical administrative costs. The horizontal axis measures housing consumption, $\mathrm{H}$, while the vertical axis measures the consumption of all other goods, $Y-H . \quad Y_{0}-H_{0}$ is the original budget line. An unconditional cash grant would shift the budget line to $\mathrm{Y}_{1}-\mathrm{H}_{1} \cdot \overline{\mathrm{H}}$ is the cost of standard housing. A voucher requiring the consumption of housing of at least $\overline{\mathrm{H}}$ would result in a new broken budget line $\mathrm{Y}_{0} \mathrm{abH}_{1}$. Public housing which presents the recipient with an all-ornothing choice resilts in the original budget line $\mathrm{Y}_{0}-\mathrm{H}_{\mathrm{O}}$ plus the single point b. Given the budget constraints and indifference map in Figure IA, in the absence of a transfer, the household would consume substandard housing at $\mathrm{H}^{\prime}$ and enjoy utility $I_{1}$. Receipt of either the voucher or public housing would raise its consumption to $\overline{\mathrm{H}}$ and its $\therefore$ utility to $I_{2}$. An unrestricted cash subsidy would result in the household remaining in substandard housing, $\mathrm{H}^{\prime \prime}$, but at utility $\mathrm{I}_{3}$. In this example, the welfare of the recipient would be maximized by an unrestricted cash grant. However, if the nonpoor derive benefits fxom the consumption of standard housing by the poor, then the other two subsidy schemes may be warranted. While the recipient prefers cash, 


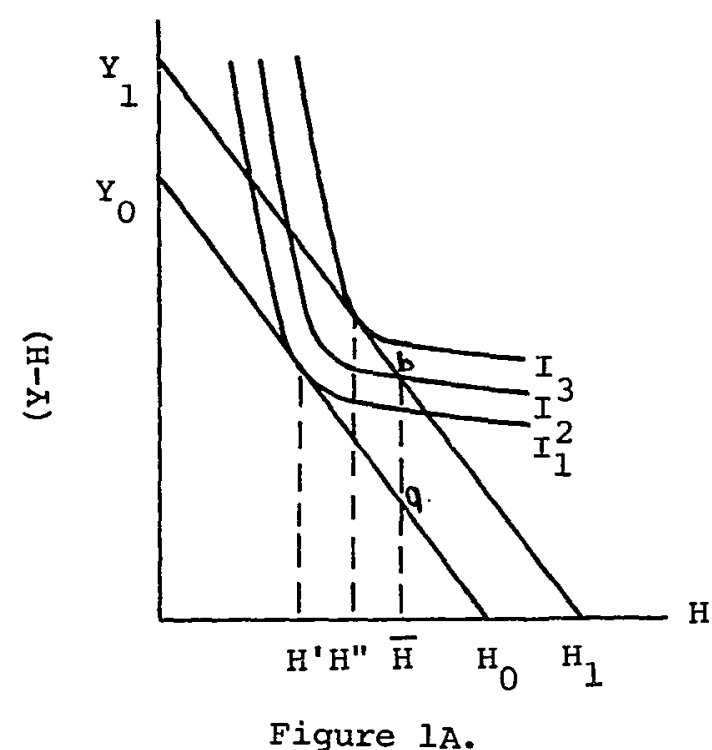

Figure 1A.

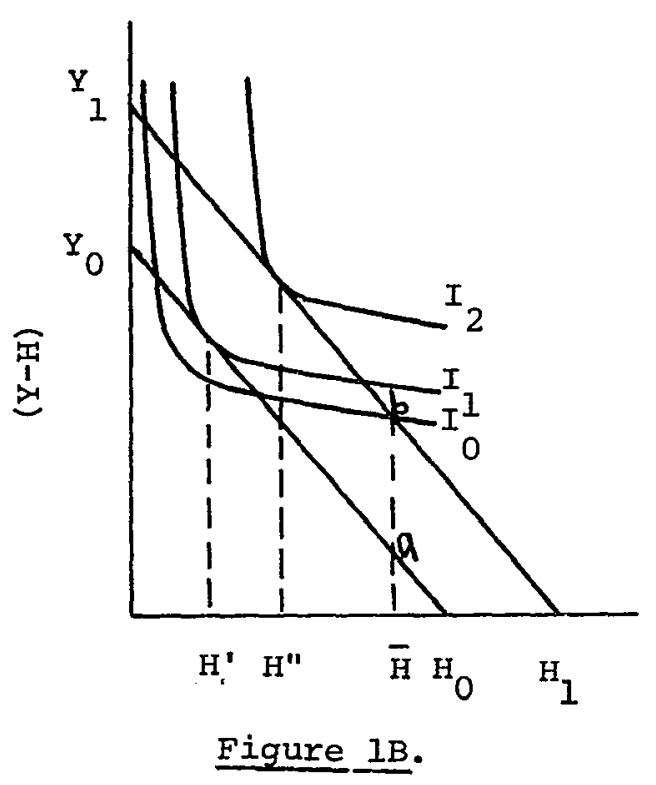

Figure 1B.

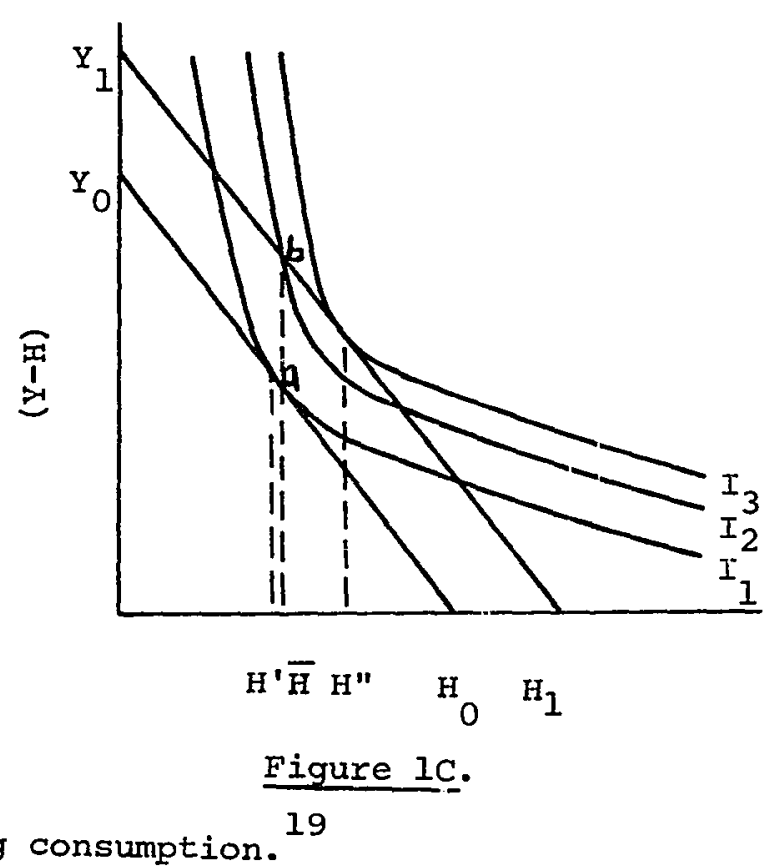

${ }^{19}$ Ibid. 
all three schemes would be acceptable to him, since all involve an improvement over pre-transfer conditions.

Orr indicates that the impact of the various transfer modes depends on the initial income of the potential recipients, as he assumes that housing consumption is income-elastic. Figure is depicts a situation in which the household will reject both the voucher and public housing as both would demand too large a proportion of the budget being devoted to housing. In this case, a change in pre-transfer housing consumption $\mathrm{H}^{\prime}$, to housing consumption $\overline{\mathrm{H}} \mathrm{de}-$ manded by the voucher and public housing, would result in a decline in utility from $I_{1}$ to $I_{0}$. An unrestricted cash transfer would raise utility to $I_{2}$ but would increase housing consumption only slightly to $\mathrm{H}^{\prime \prime}$. In this case, the in-kind transfer would fail to attain its objective of increasing the housing consumption of the poor since the intended beneficiary would reject the transfer and his housing consumption would consequently remain unaltered.

A different result is obtained for households at higher initial income levels. In Figure 1C, the unrestricted cash grant and the voucher have the same effect. Housing consumption will move beyond standard to $H^{\prime \prime}$ and utility will move from $I_{1}$ to $I_{3}$. Public housing will result in both lower housing consumption, $\overline{\mathrm{H}}$, and lower utility, $I_{2}$ than the other transfer forms. In this case, public housing is clearly the inferior solution, unless tine external benefits derived by the nonpoor from the poor's consumption of housing cease at the minimal level of standard housing. Increments beyond this point may be viewed by the nonpoor as excessive. From the view of the re- 
cipient, youchers are equivalent to cash when the household wishes to spend more on housing than the value of the voucher.

The preceding analysis has focused on the demand side of the transfer problem. However, frequently supply conditions have been as important in the selection of transfer modes. In some cases, in-kind transfers have been aimed not so much at "correcting" consumer choice, as at "correcting" market failure on the supply side. Tobin indicates that the crucial issue in determining whether in-kind or cash transfers are optimal is the elasticity of supply of the commodity in question. When the supply of a basic necessity of life is fixed or unresponsive to demand in the short-run, then in-kind transfers may be preferred; the transfer of generalized purchasing power would not be meaningful to the recipient if the market failed to provide him with the goods he required. ${ }^{20}$ The subsidization of demand when supply is inelastic, as in the case of medical care, may lead to rapid price escalation, instead of (or in conjunction with) increases in consumption.

Even when there are supply bottlenecks, in-kind aid to the poor, may not be the most efficient approach to the problem. Governmental intervention in the market to alter supply conditions may take several forms, just as there are many ways of approaching demand. For example, Welfeld has suggested, in relation to housing, that subsidies that

20 James Tobin, "On Limiting the Domain of Inequality," The Journal of Law and Economics, (1270), pp. 263-277.

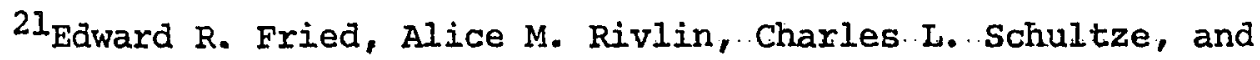
Nancy H. Teeters; Setting National Priorities: The 1974 Budget, (Washington, D.C.: The Brookings Institution, 1973), pp. 109-129. 
are not targeted specifically at low-income groups may actually create more housing for the poor through the expansion of the housing supply. This is because such large subsidies per dwelling unit are required for low-income households that the impact of such subsidies on the housing inventory is small. A more general stimulation of the housing market may be preferred. 22

\section{CRITICISMS OF THE UTILITY INTERDEPENDENCE FRAMEWORK}

While the development of the theoretical implications of utility interdependence may be vital to more effective public policy-making, there are numerous practical difficulties in translating theoretical concepts into actual public welfare programs. The "free rider" problem has been mentioned above. In addition, all interdependence models assume a uniformity of tastes with regard to redistribution within income classes. A system of taxation which is feasible to administer requires a uniform treatment of those in each income bracket. Pegging taxation to each individual's marginal evaluation of the transfer would encourage the masking of preferences and entail large administra23 tive costs. If the marginal rate of taxation exceeds the marginal increment in utility derived from a transfer for one or more individuals in a given income class, the transfer cannot, by definition, be pareto optimal. This problem is common to all public goods -- citizens are

${ }^{22}$ Irving H. Welfeld, "Toward a New Federal Housing Policy," The Public Interest, XIX, (Spring, 1970), pp. 31-44.

${ }^{23}$ George M. Furstenberg and Dennis C. Mueller, "The Pareto Optimal Approach to Income Redistribution: A Fiscal Application," The American Economic Review, LXI, (September, 1971), pp. 628-637. 
frequently confronted with a tax/service package which may be satisfactory to the "average" household in a given income class, but which many others, in the same bracket, find objectionable.

Efforts to justify specific public decisions in which some individuals are clearly "losers" generally result in a logrolling model of democratic policy-making and a defense of majority rule.

- . while majority rule might be unacceptable if outcomes are evaluated in single-issue terms, it is compatible with democracy if they are construed as episodes in a convergence process, itself having the essential properties of logrolling. Even under the Paretian ethic, majority rule may be satisfactory, given appropriate preference patterns, because the overall outcome is preferred to the inaction that would result from issue-by-isaue judgements constrained by the Pareto criterion. 24

While logrolling permits a rough reflection of differences in the intensity of preferences of different individuals on specific issues, Mishan warns that after vote trading, the entire package of decisions may result in no net transfer, even if some of the individual components of the package are redistributive. ${ }^{25}$ Von Furstenberg and Mueller concur that if redistribution is not separated from vote trading on allocational issues, it is likely that redistribution will be compromised. If majority rule is the imposition of an "elite" (the winners) on the minority (the losers) then the argument has come full circle

24

Harold M. Hochman, "Individual Preferences and Distributional Adjustment," The American Economic Reyiew, LXII, (May, 1972), pp. 353-360.

25 E.J. Mishan, "The Futility of Pareto-Efficient Distribution," The Amexican Economic Review, IXII, (December, 1972), pp. 971-976. 
and interpersonal comparisons of utility and a social welfare function are required.

\begin{abstract}
- . a meaningful program of redistribution, with the welfare of the poor improving relative to the rich, can only be achieved through a Pareto-optimal tax-transfer program if all transferors approved of the amount and form in which redistribution would be carried out at different tax shares. Barring this, redistribution always involves the imposition of a program by some elite, if it is to be effective. Conversely, strict enforcement of the Pareto criterion under such conditions results in the preservation of the status quo ante. With a less than universal desire for making transfers, the main objective tenas to be thwarted as potential losers must be compensated via logrolling. 26
\end{abstract}

The impact of transfers on the intended beneficiaries may also vary within income classes because of differences in taste among those who are equally poor. Figures $1 \mathrm{~A}-\mathrm{C}$ demonstrate the effects of various housing subsidy schemes on recipients with different preferences for housing consumption. As noted above, a cash transfer will be universally accepted by the poor, while in-kind transfers will be rejected by those intended beneficiaries whose "costs" of altering their consumption patterns exceed the "benefits" they would derive from additional housing consumption (Figure $\mathrm{lB}_{\mathrm{B}}$ ). While Figures $1 \mathrm{~A}-\mathrm{C}$ assume that taste for housing is a simple function of income, there may be significant differences in preferences for housing and other goods between those in the same income class. For example, most public programs assume that family size is a releyant variable and many take into account the age and sex of the family head. Other social, psy26 George M. Von Furstenberg and Dennis c. Mueller, op. cit. 
chological, and economic variables may also be releyant to consumption patterns.

If donors wish to insure an increase in the consumption of a particular good, such as standard housing or nutritious food, price discrimination within an income class will logically be required. Those individuals with a low desire to consume standard housing or nutritious food, will require a lower price (a bigger bribe/subsidy) to alter their consumption than will those of similar income with a stronger preference for these goods. Those with the least taste for the specified good will be those least likely to accept an in-kind transfer and will be those with the lowest pre-transfer level of consumption and therefore, those creating the greatest externalities for the nonpoor. Thus, in the absence of price discrimination, the "wrong" consumers are likely to be the beneficiaries of in-kind transfers, particularly when the supply of the transfer is limited. The price discrimination problem is analogous to the tax discrimination problem which results from the existence of donors with heterogeneous tastes for redistribution; policies which are uniform within an income class will confront some intended recipients with the "wrong" price. 27 While the administrative problems caused by attempting to tune social programs to non-income related differences are enormous, ignoring these differ-

27 George Daly and Fred J. Giertz, "Welfare Economics and Welfare Reform," op. cit. Larry orr, of. cit. Mark v. Paüy, "Efficiency in the Provision of Consumption Subsidies," Kyklos, XXIII, Fasc. 1, (1970), pp. 33-57. 
ences would lead to a violation of the Paretian standard and/or unintended policy impacts.

In addition to the problem of intraclass differences in taste, the impact of the transfer mode may be affected by significant disparities in administrative costs related to the subsidy form. While strong "goods externalities" may imply that in-kind transfers are to be preferred over cash, in-kind transfers may still be inefficient if the costs of the bureaucracy required to administer such transfers exceed the benefits to be derived from that mode. While there has been little empirical investigation of the problem, it is generally assumed that in-kind transfers are more expensive to administer than cash. As Figures $I A-C$ reveal, cash transfers are expected to have a less potent impact on the consumption of specific goods than are transfers in-kind (unless the in-kind transfer is rejected). However, a cash transfer will still have some positive impact on the consumption of the specific good, if the good is normal or superior. The extent of the impact depends on the income elasticity of the good. In some cases, (Figure 1C), a cash transfer will result in greater consumption of the good than will an all-or-nothing in-kind transfer. In sum, the appropriateness of a given transfer mode will depend on the effect of the transfer on consumption patterns, the form and intensity of the donors desires for various types of transfers, and the administratiye costs associated with the transfer form. For the theoretical implications of utility interdependence to be relevant to public policy-making, a great deal of information is required about preference patterns. Mishan cites the inability to 
operationalize the concepts as one of his principal obfections to the utility interdependence argument.

In a community consisting of some scores of millions of adults, knowledge of the requisite pattern of interdependence is for all practical purposes unattainable. 28

To fit the Paretian criterion, each person must individually benefit. Thus detailed information about each person is necessary to insure the consent of everyone involved. Even if such information could be gathered, the costs of such an undertaking might well outweigh the benefits of any scheme adopted.

In addition to these practical problems, Mishan and Musgrave both question the validity of the entire concept of treating distributional decisions in a Paretian context. Mishan contends that redistribution may be judged Pareto optimal only if the pre-transfer distribution of income is taken as given. Since the pre-transfer distribution is only one of a virtually infinite number of distributions that might have occurred with the same resource base, the choice of the pre-tax distribution on which to base transfers is a matter of ethics, not a matter of efficiency. Accepting the prevailing income distribution as given involves non--Päretian criteria and, in effect, legitimizes the prevailing power relationships. In essence, the problem becomes one of social contract determination.

28 E.J. Mishan; op. cit., p. 973.

29 Ibid., p. 974. Richard Musgrave, "Pareto Optimal Redistribution: Comment," op. ait. 
Hochman concedes some of the points made by Mishan and Musgrave.

- . the Paretian logic may be able to explain significant aspects of distributional choice, they do not define or produce "social justice". After all Pareto-optimal transfers, the community must still choose, somehow, among a residual set of Pareto-optimal distributions, each of which corresponds to a different system of rules and rights to property and human capital. No one of these distributions is uniquelyy optimal, and each, potentially, is Pareto efficient. Still, once the argument is brought this far, consideration should be given to the usefulness of extending the Paretian line of reasoning to the constitutional level of abstraction at which rights and rules themselves are determined. 30

Another complication in the utility interdependence argument is introduced by Polinsky. He indicates that the utility interdependence models deal only with marginal Pareto optimal redistribution. Polinsky contends that there are cases when redistribution is Pareto optimal beyond the margin when income transfers would be rejected on the basis of marginal considerations. For example, Mutt giving Jeff a dollar may have such a limited impact on changing Jeff's consumption pattern or utility that Mutt would consider the investment a poor one. Jeff may waste the dollar, from Mutt's point of view, by spending it on liquor, etc. However, if Mutt gave Jeff several thousand dollars, Jeff might become an upstanding member of the community, pleasing both recipient and donor. Polinsky concludes that individual shortsightedness will generally not result in the perception of Pareto optimal points beyond the margin and that a case for governmental coercion may be made.

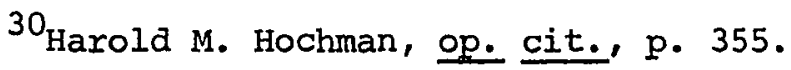

${ }^{31}$ A. Mitchell Polinsky, "Shortsightedness and Nonmarginal Pareto Optimal Redistribution," The American Economic Review, LXI, (December, 1971), pp. 972-979. 
In assuming that government will be able to respond, while individuals cannot, Polinsky ignores the strong tendency for governmental decision-making to be conservative in the extreme. ${ }^{32}$ Lindblom maintains, "Usually . . though not always, what is feasible politically is policy only incrementally, or marginally, different from existing policies." 33 When last year's budget is the best guide to this year's budget, it is as unrealistic to expect official policymakers to leap beyond the margin, as it is to expect private individuals to do so.

The theoretical development of the utility interdependence argument suggests the importance of empirical investigations which might verify the existence of hypothesized interdependence and to trace its patterns. Despite the significance of the criticism of the utility interdependence argument, the establishment of large public transfer programs testify to the likelihood of some sort of benevolent interdependence. Whether such transfers may be justified by the Paretian criterion, strictly construed, is more problematic. In addition to the sheer magnitude of public transfers, the proliferation of in-kind programs, suggests that interdependence may frequently be of the goods-specific form. In the following chapters, the case for in-kind income transfers will be examined in the context of the new developments in welfare theory presented in this chapter.

${ }^{32}$ Charles E. Lindblom, The Policy-Making Process, (Englewood Cliffs, N.J.: Prentice-Hall, Inc., 1968). Aaron Wildavsky, The Politics of the Budgetary Process, (Boston; Little, Erown and co., 1964).

${ }^{33}$ Charles E. Linablom, op. cit., p. 26. 
CHAPTER III

TRANSFERS IN-KIND: BACKGROUND MATERIAL ON THE LOW-INCONE HOUSING AND FOOD STAMP RROGRAMS

\section{Introduction}

An empirical investigation of the dynamics of "goods-specific" utility interdependence will focus on two major in-kind programs: the low-income housing and the food stamp programs. These programs were selected because of the dominance of food and housing expenditures in the budgets of the poor and because of the strong public interest in directing transfer payments to these areas. The Bureau of Labor Statistics" (BLS) "Lower Budget" for a hynothetical family of four in the Autumn of 1973 reveals that out of a total budget of $\$ 8,181, \$ 2,440$ or 308 was allocated to food and $\$ 1,627$ or $20 \%$ to housing. 1 For lower income households, these basic consumption categories command an even greater share of the budget. The public interest, as expressed through the political process, in food and housing programs is revealed in Table II which indicates that approximately one-third of need-tested inkind transfers were targeted to these areas.

\section{LOW INCOME HOUSING ROLICX}

Goals and Background

Two major goals have guided the federal low-income housing program

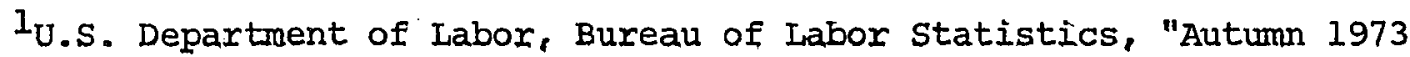
Urban Family Budgets and Comparative Indexes for Selected Urban Areas," (June 19, 1974), mimeo., p. 2. 
since its inception in the 1930's: 1) the desire to increase and upgrade the housing supply and 2) the effort to insure all American households decent housing at a "reasonable" rent/income ratio. As a result, housing policies have been oriented to stimulating housing production, eradicating slums, and redistributing income in-kind to the house poor. (The house poor are generally defined as those households compelled to allocate more than 258 of their income to housing to command standard quality in the unsubsidized market.) While housing subsidies are now dwarfed by expenditures on Medicaid and food stamps (see Table II), housing subsidies preceded these medical and food assistance effort by three decades. The long history of public interest in housing reflects the importance of the housing industry to the American economy and the relatively high visibility of the external diseconomies associated with slum housing. Proponents of subsidized housing have always emphasized the indirect benefits accruing to the larger community from improved housing for the poor. Most housing policy discussions assume that utility interdependence between taxpayers and tenants of poor housing exists and that it is of a "goods-specific" nature. Substandard housing is assumed to impose external costs on those who view it (most frequently on the journey-to-work) as well as private costs on those who must dwell in it. In addition, poor housing has been associated with the spread of communicable diseases, high crime rates, poor educational attainment and other problems which create burdens for the larger community. While the unique contribution of the physical environment is unclear and very difficult to docu- 
ment, social cost arguments in the field of housing have generally been quite persuasive to policymakers.

While low-income housing programs have existed for forty years, political support for them has vacillated over time. Housing policies have periodically encountered stiff Congressional resistance and executive displeasure. Goal shifts have frequently occurred in an effort to react to program criticisms. In the $1950^{\prime} \mathrm{s}$ and early $60^{\prime} \mathrm{s}$, interest in providing low rent housing was all but supplanted by an emphasis on the exadication of slums through urban renewal. Low rent units were destroyed; replacement housing was aimed at the liiddle and upper income market; and large parcels of cleared land were reserved for commercial and civic structures. The Housing and Uxban Development Act of 1968 refocused attention on the "house poor" but acute official dissatisfaction with program operations, particularly in the scandal ridden 235 program, culminated in an executive "freeze" on housing programs in 1973. Housing programs are currently back in business, but have shifted their emphasis. Programs which stress utilization of the existing rental market will receive priority rather than those providing new rental units or home ownership for the poor. In sum., low-income housing programs have had a long, but uneven, history of public support.

Congressional interest in subsidized housing has been bolstered by concern for the health of the construction industry. The earliest federally funded public housing projects in the 1930's were aimed at creating employment as much as they were aimed at creating housing. New housing starts aided by direct federal assistance have been a small, 
but increasing percentage of total starts. Kristof reports a gain of assisted starts from 38 in 1961 to 128 in 1968. Despite this small direct impact on new construction, Congress has provided considerable indirect stimulation for the housing industry through favorable tax treatment and the manipulation of the supply of credit. While the most overt political support for subsidized housing has come from those who express concern for the high private and social costs of slums, other, less frequently identified, beneficiaries of government subsidies are the builders, contractors, and other private and governmental intermediaries involved in the supply of subsidized units.

Housing Market Conditions: Supply and Demand Elasticity

All established low-income housing subsidy programs direct payments to housing suppliers rather than to housing consumers. While new programs have provided the prospective tenant with a choice of accomodations far greater than the traditional public housing program, housing subsidies are still of an all-or-nothing variety. The consumer cannot regulate the amount of housing he consumes nor can he allocate all or part of his housing subsidy to non-housing expenditures. American housing programs, in their avoidance of demand subsidies have reflected certain assumptions about the operation of the housing market which require careful scrutiny. Demand subsidies have typically been

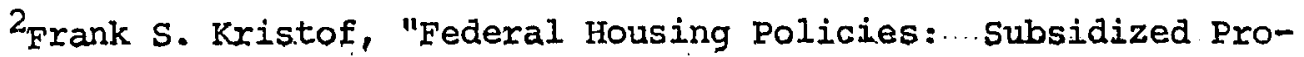
duction, Filtration and Objectives: Part I," Land Economics, XPVIII, 4. (November, 1972), p. 310. 
rejected on the grounds that the supply of housing is inelastic and that consequently, demand subsidies would result in inflated housing prices rather than increased housing production and improvements in the housing stock. In addition, the construction of new units for low-income households has been justified on the grounds that a less targeted stimulation of housing production would fail to "filter down" and improve housing conditions for the poor.

Lowry's model of the filtering process is an example of the view that the turnover of housing stimulated by new production fails to provide those at the bottom of the chain with adequate accomodations. Lowry contends that as new housing is added to the stock, existing housing declines in value, and that landlords of existing housing are encouraged to disinvest and undermaintain their holdings. Thus the housing available to the poor tends to be of unsatisfactory. quality 3 Kristof challenges Lowry's view of filtering primarily on the grounds that income is exogenous to his model. If changes in real income are included in a filtering model, quite different conclusions about the efficacy of the process may be warranted. Kristof has traced changes in the housing inventory from 1950 to 1969 and finds a remarkable record of improvement during that period. During the 1960's there was a net increase of $10,353,000$ units despite a loss of $6,761,000$ units from the housing inventory. The number of substandard units declined by $70 \%$ from 17 million to 1950 to 5 million in 1969. Crowded

3 Ira S. Lowry, "Filtering and Housing Standards," Land Economics, XXXVI, 4, (November, 1960), pp. 362.270. 
standard units increased only slightly from 3,957,000 in 1959 to

4,269,000 in 1969. The average number of rooms per person increased from 1.42 in 1950 to 1.65 in 1969. New construction more than kept up with population growth; 1.5 new units were added for each net addition to households. 4 kristof concludes,

These housing gains were accompanied by, and in large part were attributable to, advances in family income. Only rising incomes whose rate of increase equaled or exceeded rent and house price rises could sustain the high volume of new construction experienced over most of the past two decades. 5

A closer investigation of the empirical evidence reveals that complex movements within the housing stock contributed to the net trends. During the $1950^{\circ} \mathrm{s}$ Kristof found that over one million of the substandard units were newly constructed while five million substandard units were upgraded to standard. Thus the housing inventory appears to simultaneously have filtered downward and upward in a way that filtering models fail to explain. 6

In an effort to further investigate the response of the housing market to new construction, Kristof and Winnick in New ¥ork City and the Survey Research Center of the University of Michigan covering the nation traced the chains of moves stimulated by new units. The previous housing of the occupants of new housing was located and the in-

${ }^{4}$ Frank s. Kristof, op. cit., pp. 313, 315.

Frank S. Kristof, "Federal Housing Policies: Subsidized Production, Filtration and objectives: Part II," Land Economics, XLIX, 2, (May, 1973), p. 170.

${ }^{5}$ Ibid., Part I, p. 316.

6

Ibia., Part I, p. 319. 
come and other characteristics of the household moving into the vacated unit were ascertained. This process was followed until a chain of moves terminated with the demolition of a vacated unit or with new household formation. Kristof concludes that "By and large, the turnover of housing generated in central cities has permitted lower income segments of the community to inherit better housing." 7 While Kristof's analysis considers the housing market as a whole, he does not investigate, in detail, the barriers that may inhibit the downward flow of sound units to the nonwhite poor.

Krigtof makes a sharp distinction between housing shortages which he characterizes as "one of the great mythologies of the housing discussion" 8 and the ability of the poor to effectively demand available housing which he concedes is a seriously problem. The problem of housing abandonment illustrates the issue. Abandonment has alarming consequences for the viability of entire neighborhoods as vacant buildings serve as a magnet for addicts and criminals who spur households in surrounding buildings to flee the area if they possibly can. Sternlieb notes that many of the units being lost are essentially sound; not necessarily the worst of the housing stock. ${ }^{9}$ Kristof views the abandonment of buildings, in part, as a sign of slack in the

7 Ibid., Part II, p. 170.

8 Ibia.

${ }^{9}$ George Sternlieb, "Abandonment and Rehabilitation: What is to be Done? " - Papers Submitted to the Subcommittee on Housing Panels on Housing Production, Housing Demand and Developing a Suitable Living Environment, House of Representatives, Committee on Banking and Currency, (Washington, D.C.: U.S. Government Printing Office, June, 1971), pp. 315-331. 
housing market created by new construction, but he also notes that the inability of low-income households to pay rent sufficient to maintain buildings has contributed heavily to many landlords' decisions to abandon their investments. 10 The failure of lending institutions to finance rehabilitation in poor neighborhoods has also been a significant factor. While conceding the complexity of the issue, Kristof concludes that supply elasticity is not a serious problem and thus recommends a housing allowance approach that would direct subsidies to consumers in an effort to make the housing demand of low-income households more effective. Dêr Leeuw, Welfeld, Lowry and other housing experts have reached the same conclusion.

Muth also attacks the assertion that demand subsidies will

merely result in rent hikes because of the unresponsiveness of supply.

The assertion, of course, ignores competition among landlords. Though it is in the interest of any single individual landlord to try to charge as much as he can for a given dwelling unit, he can charge monopoly prices only if he has a monopoly. Otherwise, if he raises his rentals above those charged by other landlords, his tenants will move to other dwellings. Vacancies at all rent levels generally exist where there is no rent control, so that better housing is available at higher rentals. 12

${ }^{10}$ Frank s. Kristof, op. cit., Part I1.

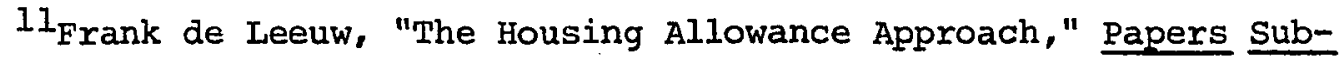
mitted to the Subcommittee on Housing Panels ... op. cit., pp. $54 \overline{1-554}$. Ira s. Lowry, "Housing Assitance for Low Income Families: A Fresh Approach, : Papers Submitted to the Subconmittee on Housing Panels... op. cit., pp. 489-524.

Irving H. Welfeld, America's Housing Problem: An Approach to Its Solution, Evaluative Studies 10, (Washington, D.C.: American Enterprise Institute for Public Policy Research, October, 1973).

12 Richard F. Muth, Public Housing: An Economic Evaluation, Evalutive Studies 5, (Washington, D.C.: American Enterprise Institute for Public Policy Research, March, 1973). 
Since the housing market is characterized by a large number of independent producers, collusion between them is unlikely.

Olsen lends some theoretical support to the notion that the housing market would respond to a demand subsidy by increasing supply. He contends that the housing market exhibits most of the characteristics of a competitive market and that a housing allowance approach would result in higher prices only in the very short-run. The chain of shifting opportunities for profit should eventually stimulate new construction and an increase in supply. ${ }^{13}$

Existing housing subsidy programs rest not only on the questionable premiss of inelastic supply, but also on an assumption of inelastic demand. Housing proponents contend that general cash transfers to the poor would not insure a socially acceptable level of housing consumption. In-kind transfers are viewed as essential to diminish the external diseconomies associated with the "underconsumption" of housing by the poor. De Leeuw, in a paper analyzing the results of several researchers, concludes that the income elasticity of rental housing in the U.S. is between 0.8 and 1.0 , but indicates that income elasticity appears to be lower for nonwhite households. 14 De Leeuw suggests that the price elasticity of the demand for rental housing is

13

Edgar O. Olsen, "A Competitive Theory of the Housing Market," The American Economic Reyiew, LIX, (September, 1969), pp. 612-621.

14

Frank de Leeuw, .."The Demand.for Housing:-A Reyiew of CrossSection Evidence," The Review of Economics and Statistics, LIII, I, (Februaxy, 1971), p. 1 . 
about $-1.0 .^{15}$ Thùs general income increases, untied to housing, would result in increased housing consumption, but such increases would undoubtedly be less per household than under our present housing programs. If taxpayers have a strong preference for increasing the housing conumption of the poor, as an assumption of "goods-specific" utility interdependence would indicate, then in-kind transfers may maximize utility. Whether or not tied transfers are preferable to cash hinges on the strength of taxpayers' preferences, the actual shape of consumption patterns and the relative costs of the transfer modes. Whether or not tied subsidies should be directed to the suppliers or the consumers of housing hinges on the dynamics of the housing market. All of these issues require further empirical investigation, but the assumptions of inelastic supply and demand underlying present policies have little in the way of hard data to support them.

Low-Income Housing Programs: Description and Criticisms

Public intervention in the housing market has taken several forms. While housing subsidies are conventionally associated with programs directed at the poor: Aaron demonstrates that the largest public housing subsidy, by far, is the favorable treatment of homeowners in the income tax code. Aaron found this indirect subsidy was worth $\$ 7$ billion in 1966; only $8 \%$ of which accrued to taxpayers with annual incomes below

15

Frank de Leeuw and Nkan ta Ekanen, "Time Lags in the Rental Housing Market," Urban Institute Reprint 159-112-19 (Washington, D.C.: The Urban Institute, February, 1974), p. 41. 
$\$ 5,000.16$

The oldest housing program directed at the low-income population is the Public Housing Program which prior to the 1960's subsidized only the direct public provision of new units. Under this program, the federal government contracts with Local Housing Authorities (LHAs) for the construction of new dwelling units which rent to the eligible at rates considerably below those prevailing in the unsubsidized market. The new construction is financed by the federal government which pays the interest and amortization costs of tax exempt bonds issued by the LHAs. The federal subsidy includes both this direct capital component and an indirect component in the form of federal revenue foregone due to the tax-free status of the bonds. Public housing also receives a small indirect subsidy from loci governments in the form of exemption from local property taxes. While LHAs make payments to local governments in lieu of property taxes, these payments are considerably less than property taxes would be on comparable structures. While nearly all of the financing for public housing comes from the federal government, the units are planned owned and managed by the LHAs.

Traditional public housing programs have been widely criticized as inequitable and inefficient. By traditionally concentrating on new construction for the poor, very large per unit subsidies are required. Large per unit subsidies mean that few of the eligible receive assis-

16

Henry J. Aaron, Shelter and Subsidies: Who Benefits from Federal Housing policies?, (Washington, D.C.: The Brookings Institution, 1972), p. 163 . 
tance and that the pxogram's impact on the total supply of housing is negligible. Muth estimates that, as an outer limit, public housing accomodates about $15 \%$ of the eligible. 17 Most estimates are considerably lower.

Muth also focuses on the inefficiency of public construction and the perverse incentives created by the subsidy structure. Prior to the Brooke Amendments to the Housing Act of 1968, federal subsidies were available only for capital costs. This encouraged LHAs to substitute capital for cirrent expenditures. Maintenance was neglected and capital costs inflated since subsidies from Washington were viewed as "free".

Valuing capital and current inputs in public housing at their opportunity cost elsewhere in the economy, the resource cost per unit of public housing is $21 \%$ greater than it would be if the IHAs were to bear the full capital costs of the real estate they use. 18

In an effort to improve the efficiency of public housing construction, the Turnkey program was introduced. Responsibility for development was shifted from the LHAs to the private sector. Under the Turnkey program, private contractors develop housing projects, sell them to the LHAs and turn them over to public management upon completion. Welfeld notes that the original impact of the program was to substantially reduce development costs. However, the lax supervision of private developers also led to some well-publicized fraud which in turn resulted in an elaborate code of development regulations. Welfeld

${ }^{17}$ Richard F. Muth, op. cit., p. 30.

${ }^{18}$ Ibid., pp. 19-20. 
claims that as a consequence, "... the development process was made so much more complex that the Turnkey method is now more expensive than IHA designed and managed construction. "I9

In addition to high development costs and the failure to serve a significant percentage of the eligible, public housing has been criticized for pricing the neediest out of the program. Prior to the Brooke Amendments of 1968, tenant rents were required to cover all operating costs. As operating expenses rose, many LHAs confronted the choice of bankruptcy or of manipulating admissions so that those households too poor to pay rent sufficient to cover operating costs were balanced by households who could pay rent in excess of operating costs. Too large a concentration of the very poor threatened the solvency of the LHAs; thas the small existing supply of public housing was allocated in a way which did not necessarily favor the neediest. The Brooke Amendments opened the door for federal subsidies for operating as well as capital expenditures. While the Brooke Amendments permit a greater concentration of benefits on the very poor, Muth and Welfeld note that they have also created a structure of incentives which is not conducive to efficient management. Since operating deficits as well as capital costs are now picked up by the federal government, IHAs have little incentive to reduce these deficits. De Leeuw investigated public housing operating costs from 1968-71 and discovered that operating expenditures have been rising more rapidly than the inflation of inputs. For example, during 1970-71 costs in-

19 Irving $\mathrm{H}$. Welfeld, op. cit., p. 17. 
creased 11.38 in large housing authorities and 8.48 in small housing authorities. In the same period the estimated contribution of inflation was only $68 .{ }^{20}$ High operating expenditures do not appear to be linked to greater resident satisfaction and improved maintenance. Sadacca, Loux, Isler and Drury conducted an extensive survey of management practices and operating costs in public housing programs. They concluded that LHAs with high performance in terms of resident and staff satisfaction and building maintenance were those with significantly lower operating costs. 21

other objections to public housing programs have centered on the spatial distribution of benefits -- both within and between urban areas. The concentration of the poor in large projects in central cities is viewed by most as exacerbating the difficulties associated with this population. Many social scientists assume that low-income households reinforce one another's socially costly behavior and that spatial integration with the middle-class would help alter this pattern. Housing authorities have been accused of substituting new, public slums for old, private ones. However, others view the concentration of the poor as more benigh. Concentration may lower the costs of social service delivery. Furthermore, many low-income groups fear that dispersion would dilute the political,

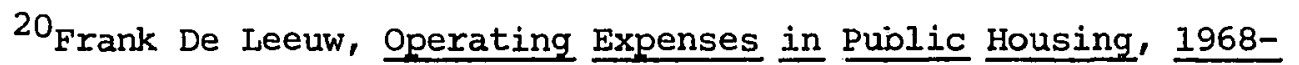
71, (Washington, D.C.: The Urban Institute, 1973), p. 29.

${ }^{21}$ Robert Sadacca, Suzanne B. Loux, Morton I. Isler, and Margaret J. Drury, Management Performance in Public Housing, (Washington, D.C.: The Urban Institute, 1974). 
social and cultural benefits they derive from the geographic concentration of their members.

Efforts to scatter projects throughout metropolitan areas have met with powerful political resistance, strongly linked to issues of race. 22 This resistance has effectively prohibited the significant dispersal of projects, with the exception of those constructed for the elderly. As the elderly do not pose the explosive issues of school integration and crime, the integration of the low-income elderly into middle-income neighborhoods has been relatively smooth. Conflict is minimized because the elderly are essentially middle-class in behavior pattern. Friedman notes that public acceptance of early public housing programs during the Depression was linked to the assumption that tenants would come from the "submerged midale-class" temporarily injured by the economic crisis. He contends that enthusiasm for public housing waned as it became clear that its inhabitants were increasingly lower-class and black in origin. Prior to the tenants' rights movements of the 1960's most LHAs attempted to assuage public opinion by selecting lower-class families for occupancy who were most middle-class in structure and behavior. Those households with severe problems were not admitted to public housing in the first place or were often arbitrarily ousted if accidently let in. ${ }^{23}$ These unwritten policies have

\section{2}

Mario M. Cuomo, Forest Hills Diary: The Crisis of Low Income Housing, (New York: Random House, 1974).

$$
23
$$

Lawrence M. Friedman, Government and Slum Housing: A Century of Frustration, (Chicago: Rand MC Nally and Co., 1968). 
largely been replaced, but as more "problem" families enter public housing, the acceptability of dispersed sites to the larger community has probably diminished.

The low-income housing program has also been attacked for its uneven distribution of benefits across the nation. Von Furstenberg compared the dispersion of subsidized housing with the distribution of low-income households and concluded:

... the probability of a low-income family receiving Federal housing assistance varies drastically from state to state. In general, the richer the state, the more assisted housing units are provided for its (relatively fewer) low-income families and the poorer the state, the worse the odds. .... there is a systematic undersupply in the West and an oversupply in relation to the needs of the East. 24

In an attempt to respond to the numerous criticisms of public housing programs several new approaches to low-income housing have evolved. These efforts emphasize increased reliance on the private market. The section 23 Leasing Progran, enacted in 1965, allows LHAs to lease units from private owners and sublet them to low 0 income households at below-market rents. The program has the advantage of avoiding the excessive development costs associated with direct public construction and ownership. Other advantages of the program are the scattered location of sites in existing neighborhoods and the greater anonymity this dispersal permits the tenants. While the program uses the private real estate market and the existing stock of housing more heavily than

${ }^{24}$ George M. Von Furstenberg, "The Distribution of.Fedexally.Assisted Rental Housing Services by Regions and States,"... The Economics of Federal Subsidy Programs: Part 5 - Housing Subidies, U.S. Congress, Joint Econrmic Committee, (Washington, D.C.: U.S. Government Printing Office, 1.972), p. 611 . 
did traditional public housing programs, the LHA remains an actiye intermediary between housing consumers and housing suppliers. The LHA searches for units, inspects and reinspects them, negotiates leases, collects and pays rents, and assumes responsibility for maintenance. $^{25}$

Section 8 of the Housing and Community Development Act of 1974 establishes the Housing Assistance Payment Program as the major program for low-income households. Section 8 is basically an expansion of the section 23 concept, with the important difference that the household will be permitted to locate its own housing. The LHA will still inspect the unit, collect rents, and sign leases, as under Section 23. The unit must be available at or below HUD established Fair Market Rents for a given city and must be of standard quality. The subsidy will be the difference between $25 \%$ of the household's income, net of permissable deductions, and the market rent of the unit. Tenant rent will vary with tenant income, not with the cost of the unit, so the incentive structure encourages households to locate housing at or near the established maximum rent. The Fair Market Rent for a twobedroom walk-up unit in Portland has been set at $\$ 235$ for new construction and $\$ 169$ for existing construction. 26 These limits appear to be quite generous as the median gross rent (includes utilities ) for the

25 Frank de Leeuw and Sam H. Leaman, "The Section 23 Leasing Program," Ibia., pp. 642-659.

26Ronald M. Duzy, Director, Housing Programs Management, Portland Area Office, Department of Housing and Urban Development, Interview, February 18, 1975. 
Portland SMSA was only $\$ 115$ in 1970.

The Rent Supplement Program also relies on privately owned housing but restricts sponsorship to non-profit or limited profit developers. The program stresses new or substantially rehabilitated units for low-income families who must also be eldexly, handicapped, displaced by government action, victims of disaster or living in substandard housing in order to qualify. A subsidy is paid to the housing owner equal to the difference between $25 \%$ of the tenant's net income and the market rent. However, the subsidy may not exceed $70 \%$ of the rent. This limitation on the amount of the subsidy has prevented the operation of the program in high rent communities unless the program is "piggy-backed" on to one of the interest rate subsidy programs 28 Section 235 and 236 are the major interest rate subsidy programs for "lower-income" families. They were part of the Housing and Urban Development Act of 1968 and are administered directly by HUD, not by the LHAs. Section 235 and 236 subsidize, at a maximum, the difference between the cost of debt service at the market rate of interest and the cost of such service at 18. Section 235 is designed to enable families to purchase homes, while Section 236 is intended to provide rental housing. Both programs require the tenant or owner to pay the cost of debt service at 1\%. This requirement prevents the lowest in-

27 U.S. Bureau of the Census, Census of Population and Housing: 1970. Census Tracts, Final Report PHC(1)-165 Rortland, Oregon-- Washington, SMSA, (Washington, D.C.: U.S. Godernment Printing Office, 1972).

${ }^{28}$ Irving H. Welfeld, op. cit., pp. 18-19. 
come families from participating in the program. In 1971, the median family income in public housing was $\$ 2,548$ but in 236 it was $\$ 5,303$ and in 235 it was $\$ 5,760.29$ Considerable criticism has been directed at this failure of two major housing subsidy programs to reach the neediest. In addition to being criticized as inequitable, the 235 program has been plagued by fraud and defaults. 30

Both the 235 and 236 programs are characterized by incentive structures which encourage inflated costs. In the 235 program, the homebuyer's payments hinge on his income, not on the size of his mortgage. Thus the subsidized household is encouraged to purchase expensive housing (within the program limits) because it does not bear the cost of its extravagance. Large public subsidies have permitted the small number of households fortunate enough to enter the 235 program to be housed in relative luxury.

As many as 50 percent of the households are being overhoused relative to the national average, and, therefore, oversubsidized. Approximately $50 \%$ of the families entering the section 235 program would only qulify for a two bedroom apartment under most of HUD's multifamily housing programs. Nevertheless, virtually all of the homes in this program have three or more bedrooms. 31

29

Donald D. Kummexfeld, "The Housing Subsidy System," Papers Submitted to the Subcommittee on Housing Panels ... op. cit., p. 469.

${ }^{30}$ Irving $\mathrm{H}$. Welfeld, op. cit., p. 22.

U.S. Congress, Joint Economic Comittee, Subcomittee on Priorities and Econory in Government, Housing Subsidies and Housing Rolicy, (Washington, D.C.: U.S. Government Printing Office, March 5, 1973).

31 Irving H. Welfeld, op. cit., pp. 20-21. 
The structure of the 236 program does not reward efficiency either. Tax benefits and other profits permitted builders increase with the size of their mortgage. As a consequence, development costs have been high and the "market rents" in the 236 units have not been competitive with those in comparable unsubsidized units.

In sum, while attempts have been made to break away from direct public provision of new units and to increase reliance on the private market, the new programs have not escaped the old charges of inequity and inefficiency. In many ways, the new programs have introduced the illusion of a competitive market without its discipline. While private suppliers are utilized, their profits are either independent of their efficiency, or, in the case of 235 and 236, linked to inefficiency. The housing tenant is not encouraged to economize either since he is not allowed to profit from limiting his housing consumption. Decision-making remains overwhelmingly bureaucratic. The Public Housing Program (both conventional and Turnkey) and the leasing program for low-income households will be examined in the context of the "goods-specific" uilitity interdependence framework. The Rent Supplement, 235, and 236 Programs will not be investigated further iecause of their smaller impact on the federal budget (Table II) and because 235 and 236 largely fail to reach the poverty population. 
THE FOOD STAMP PROGRAM

The Politics of Hunger

The current Food Stamp Program began in 1961, on a pilot basis, through executive action of President Kennedy. Congress made the Food Stamp Program permanent with the passage of the Food stamp Act of 1964. The major obstacle to passage was getting the bill out of the House Agriculture Committee which was dominated by rural interests who viewed food stamps as a welfare program for urban areas. Most committee members favored the established surplus commodities distribution program as it was overtly linked to farm price support policies. Vote-trading finally allowed the bill to reach the House floor where urban Democrats agreed to support the wheat-cotton bill in exchange for the votes of rural Democrats on food stamps. Democratic unity made Republican support unnecessary; voting in the House was on straight party lines. In the Senate, support for food stamps was so strong that passage was obtained by voice vote. 32

Program growth was modest for a number of years, but accelerated rapidly in the '70s (Table I). As food stamp participation grew the commodity program was phased out. Commodity distribution remained in operation on only a few Indian reservations. The expansion of the Food Stamp Program has been strongly linked by political analysts to the tremendous publicity given the "hunger issue" by the media during the

32 Randa11 B. Ripley, "Legislative Bargaining and the Food.stamp Act of 1964,!!.in.Frederic N. Cleaveland and Associates (eds), Congress and Urban Problems, (washington, D.C.: The Brookings Institution, 1969). 
1960's. John F. Kennedy, press in tow, was visibly affected by the poverty he viewed during the West Virginia primary. The establishment of a pilot Food stamp Program was one of his first acts as president. In April, 1967, Senators Robert F. Kennedy and Joe Clark received extensive coverage on their trip to the Mississippi Delta where they were shocked at the extent of hunger and malnutrition. ${ }^{33}$ In May, 1968, CBS News presented "Hunger in America" which opened with the death of a baby attributed to starvation. The program drew a flood of letters to Congressmen demanding an expansion of the domestic food programs. Congress was disposed to respond despite Secretary of Agriculture Orville Freeman's denial of the CBS claim that there were 10 million hungry or starving Americans. In addition, 1968 witnessed the publication of Hunger U.S.A. by the Citizens' Board of Inquiry into Hunger and Malnutrition in the United States. Hunger U.S.A. identified 256 "hunger" counties and contained suggestions for expanding the food program. 34 Hunger had become a hot political issue.

In hearings before the senate select Committee on Nutrition anc Human Needs in 1969, both Senator Ralph Yarborough of Texas and Dr. Thomas E. Bryant, Assistant Director, Office of Economic Opportunities for Health Affairs, directly acknowledged that the publicity given to hunger had created the political environment conducive to expanded food programs. Yarborough commented:

${ }^{33}$ U.S. Senate, Select Committee on Nutrition and Human Needs, Hearings on Nutrition and Human Needs, Part 2--USDA, HEW, and OEO Officials,

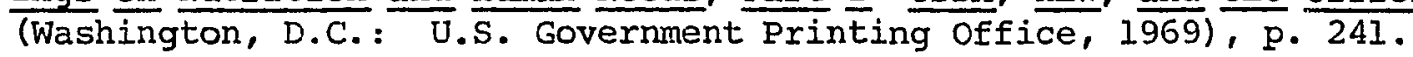

34Judith A. Segal, Food for the Hungry: The Reluctant Society, (Baltimore: The Johns Hopkins University Press, 1970), pp. I2-14. 
I believe we have come to the point where a majority of Americans want to see hunger and malnutrition ended. I think that the dramatization of the problem during the past 2 years by various senators and senate committees, by some Members of the House, by your own Department (Agriculture), and by such private organizations as the Citizens Board of Inquiry and CBS television, has arousea the American conscience to the point that at last we will see the elimination of poverty, hunger, and malnutrition. 35

Bryant testified:

... the publicity, in the best sense of that word, that has been given to these issues has in a sense made many millions of Americans aware of the problem and aware that something needs to be done about it. I don't know that it is totally desirable that it happend this way, but the publicity that has been given to this is important. 36

\section{Program Mechanics}

Ths purpose of the Food Stamp Program is to increase the food consumption of low-income households by providing them with coupons whose face value represents the cost of a minimal, but nutritionally adequate, diet. Monthly coupon allotments vary with family size and are based on the price of the Economy Food Plan, the least expensive of the five dietary plans published by the U.S. Department of Agriculture (USDA). Prior to 1971, payment and eligibility standards were set by the states and varied considerably between them. Since 1971, schedules are uniform for the 48 contiguous states, and somewhat higher for Alaska and Hawaii. Lower per capita allotments are given to large households than to small on the grounds that there are economies of

\footnotetext{
${ }^{35}$ U.S. Senate, Select Committee on Nutrition and Human Needs, op. cit., p. 241 .

${ }^{36}$ Ibid., p. 336.
} 
scale in food purchasing. The USDA is required to update allotments every six months to reflect increases in food prices. The cost of the Economy Food Plan is the cost of a particular market basket of food. However, some changes in quantities purchased over time are made in response to changes in the relative prices of food items. ${ }^{37}$ The Census Bureau's definition of poverty is three times the cost of the Economy Food Plan, thus poverty in America is defined in real terms. 38 Most participating households must purchase their stamps, although free stamps are available to households with very low net incomes (gross income minus deductions allowed by the program). The household's purchase price depends on household size and net income under a complex formula which is intended to reflect those factors which most commonly impede a household's ability to devote adequate resources to food. The purchase price is supposed to reflect what a household would "normally" spend for food, while the subsidy is intended to augment "normal" food purchases. However, the complexity of the formula creates disparities between what households of equivalent size and gross income pay for their stamps. The subsidy or bonus value of the food stamps is the difference between the participating household's payment and the face value of the coupons. For example, as of

37U.S. Senate, Select Committee on Nutrition and Human Needs, Reference Materials to Part I Food Price Changes, 1973-74, (Washington, D.C.: U.S. Government Printing Office, 1974), p. 102.

38 U.S. Bureau of the Census, Current Population Reports, Series p. 60, no. 91, "Characteristics of the Low-Income Population: 1972" (Washington, D.C.: U.S. Government Printing Office, 1973), p. 1. 
December, 1974, a family of 4 with net income below $\$ 30$ per month would receive $\$ 150$ of food stamps free -- this household's monthly subsidy would equal $\$ 150$. A four person household with net monthly income of $\$ 200$ would pay $\$ 53$ for $\$ 150$ worth of stamps -- its bonus or monthly subsidy would equal $\$ 97$. It is possible that these two hypothetical households have similar gross incomes, but the first family may have higher medical, housing, and other deductible expenditures under the program's income calculation formula.

Food stamps may be used to purchase all food items in markets which have been approved by the Food and Nutrition Service of the USDA. Interested stores must apply to participate in the program and mist agree to abide by program regulations. Certification of a store involves the completion of a simple one page form and is virtually automatic. Most markets in urban areas participate in the program. Participating enterprises may not accept food stamps in payment for nonfood items such as paper or cleaning products and they are not permitted to make change in cash. Store coupons must be issued in lieu of change. The supermarket must bundle and cancel the food stamps as specified by the program rules and deposit them in a commercial bank. The commercial bank deposits the stamps at a Federal Reserve Bank where they are destroyed.

While the entire cost of the food stamp bonuses to participating households is borne by the federal government, the program is administered by county governments. Administrative costs are shared by federal, state and county governments. Prior to October, 1974, the 
USDA paid $62.5 \%$ of direct salary, travel and travel-related costs of personnel involyed in 1) certifying non-Public Assitance households, 2) Outreach (publicity to bring new households into the program) and 3) Fair Hearings. The remaining $37.5 \%$ was shared by the state and county. In Oregon, the county share was $30 \%$ and the state share $70 \%$ of those administrative costs not covered by USDA. While USDA's share of administrative costs appears generous, in fact, the cost sharing applied to such a small percentage of program personnel that the burden on state and local government was considerable. The USDA cost sharing did not apply to supervisory personnel, quality control investigators or data processing. A survey by the senate select Committee on Nutrition and Human Needs revealed that the USDA was actually covering only 288 of overall administrative costs for nonPublic Assistance participants. ${ }^{39}$ Administrative costs ior participating Public Assistance households are shared between HEW and state and local governments. In response to complaints from the states that the administrative burden of the Food stamp Program was prohibitive, the USDA agreed to fund $50 \%$ of all administrative costs of the program for non-Public Assistance households as of October 1, i974.40

${ }^{39} \mathrm{U} . \mathrm{S}$. Senate, Select Committee on Nutrition and Human Needs, Food Program Technical Amendments: A Working Paper, "The Administrative Cost of the Food stamp Program," (Washington, D.C.: U.S. Government Printing Office, 1974), p. 103.

40

Willard Renkin, Food stamp Coordinator, Multnomah County Oregon Welfare Department, interview, November 27, 1974. 
To receive food stamps, a household not on Public Assitance must be certified as eligible by the county food stamp office. In Multnomah County, there are five branch offices, in four geographic locations, where certification oocurs. (Further decentralization of certification is planned). The applicant must present proof of earnings, shelter expenses, tuition, medical payments, etc., in the form of receipts, cancelled checks, check stubs, etc. The certification period varies from one month to one year depending on the certification worker's appraisal of the stability of the household's income. For example, an elderly participant on Social Security is likely to be certified for a year while an 18 year old unemployed blue collar worker is likely to be certified for a month or two. When the certification period ends, the participant must be recertified -- a process nearly identical to the original certification procedure.

Certified households are mailed Authorization to Purchase cards (ATPS). In Multnomah County, the ATPs and the participant's cash payment, if any, are exchanged for the authorized amount of stamps at county food stamp offices. Stamps are issued by mail for those households with severe difficulties in traveling to issuing offices -i.e., the disabled, the senile. Public Assistance participants are mailed their stamps. In other counties, other distribution systems prevail -- some counties use commercial banks andfor post offices. In Oxegon, all counties other than Multnomah and Lane, distribute stamps through the post. office which receives 81 cents per transac- 
tion. ${ }^{41}$ In some states where banks or post offices are used, the cost per transaction is moxe; the price is negotiated by the county or the state. Transaction costs are shared by the county and the state.

It was the intention of Congress that Public Assistance recipients be automatically eligible for food stamps. By and large they are, even if their income from Public Assistance in high payment states exceeds the national income limits established for the Food Stamp Program. However, all food stamp recipients must have cooking facilities in their place of residence, although elderly or disabled participants may use their stamps for "Meals on Wheels" food delivery. A major administrative difficulty was created when the USDA refused to accept state Public Assistance income determination formulas in calculating payment schedules for Public Assistance households. Different deductions from gross income are permitted by food stamp regulations and Public Assistance rules. This means that a separate form must be completed and a separate calculation made of income for food stamps, even though the household is "automatically" eligible. Thus the food stamp program has contributed to the paper work of the Public Assistance Program which is already drowning in a sea of forms. A Public Assistance household may elect: to have a portion of its monthly check withheld in payment for food stamps and may bave its alloca-

41

Multnomah County Oregon, Department of Administrative Services, Food Stamp Division, "Comparative Services and Cost Figures, Multnomah County Food stamp Issuing vs. Post office Issuing," (December 30, 1974), mimeo., p. 2. 
tion of stamps mailed with its check. Most Public Assistance house holds receive their stamps in this manner, but the household may follow the same purchasing procedures as non-Public Assistance households if it wishes.

\section{Program Criticisms}

A barrage of criticism has been aimed at the food stamp Program since its inception. Most attacks have focused on the level of benefits and on the administrative shortcomings of the program. Welfare Rights Organizations and other spokesmen for the poor have persistently claimed that program benefits are too meager to provide a "nutritiously adequate diet" as the Food stamp Act requires. Publications of the Department of Agriculture and a deposition taken from Dr. Robert Rizek, Director of Consumer and Food Economics Research Division, USDA, state that the Economy Diet Plan on which food stamp allotments are based is deficient in four nutrients recommended by the National Academy of sciences to insure nutritional adequacy. In addition, the USDA Food Consumption Survey of 1965 revealed that less than $10 \%$ of the families spending at the level of the Economy food Plan received the Recommended Dietary Allowance (RDA) and less than

\section{2}

U.S. Senate, select Committee on Nutrition and Human Needs, Hearings: Nutrition and Human Needs - 1972; Part 3B - Unused Food Assistance Eunds: Food Stamps; Administration Witnesses, (Washington, D.C.: U.S. Goyernment Printing Office, 1972), p. 655.

43

Ibid., p. 636 . 
$50 \%$ had obtained eyen $2 / 3$ of the RDA. The USDA itself recommended the Econory Diet Plan for only temporary use and suggested that welfare agencies consider basing food allowances on the Low Cost Food Plan which is about $25 \%$ more expensive than the Economy 45 Plan.

The cost of the Economy Diet Plan is calculated for hypothetical families of various sizes. For example, the USDA family of four consists of parents ages 20-35, a boy, age 9-12, and a child age 6-9. The family members are assumed to engage in only moderate physi46

cal activity. Thus the food stamp allowance, based on the needs of this hypothetical family, may be generous or niggaraly for real. four person households, depending upon their similarity to the hypothetical family. A household with adolescent children and a male head would be likely to find their coupon allotment inadequate, while a mother with three preschool youngsters might find the same allotment generous.

The introduction of uniform national standards in 1971 was intended to simplify administration and insure equitable treatment for recipients in different states. However, uniform standards have been

44 Ibid., pp. 759-760.

45 Ibid.

46 Ibid., p. 637. 
attacked as inequitable to those participants residing in high food 47

cost areas. Arthur Schiff, Director, New York City Food Stamp

Program, testified before the Senate select Committee on Nutrition

and Human Needs that the program, in effect, transfers money from the 48

North to the South. Food costs do vary substantially between

urban areas. The Bureau of Labor Statistics (BLS) "lower" budget

for a hypothetical family of four in the Autumn of 1973 found that

the annual cost of the same market basket of food at home ranged from

$\$ 1852$ in Dallas to $\$ 2300$ in New York; a difference of $\$ 448$ or $24 \%$.

(The food expenditures in the BIS"lower" budget are based on the 49

USDA's Low Cost Diet Plan). Other critics of benefit levels have

noted that the USDA prices its market baskets at supermarket chains

whose prices are lower than the Mom and Pop stores frequented by many 50

low-income shoppers.

Another frequent complaintis that despite mandated semi-annual

${ }^{4}$ U.S. Senate, Select Committee on Nutrition and Human Needs, "Hunger 1973" and Press Reaction, (Washington, D.C.: U.S. Government Printing Office, 1973), p. 4.

48

U.S. Senate, Select Committee on Nutrition and Human Needs, Hearings: Nutrition and Human Needs -- 1971, Part 3: Food Stamp Re-

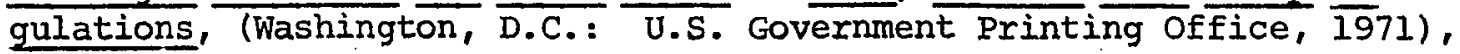
p. 794 . Table 1.

${ }^{49}$ U.S. Department of Labor, Bureau of Labor statistics, op. cit.,

50 Howard Kunreuther, "Why the Poor May Pay More for Food: Theoretical and Empirical Evidence," U.S. Senate, Select Conmittee on Nutrition and Human Needs, Reference Material to Part I, Food Price Changes, 1973-74, op. cit., pp. 110-125. 
schedule up-dates, increases in benefits. haye failed to match increases in the cost of food. The National Nutrition Policy study issued in June, 1974 notes that the "poor person's price index" (a price index weighted to reflect the consumption patterns of low-income households) has advanced more rapidly than the Consumer Price Index (CPI). The Policy Study argues that in periods like 1973-74 when food prices rose more rapidly than other-prices, poor households, which spend a larger percentage of their budget on food than do middle and upper income households, suffered disproportionately from inflation. As upper and midale income consumers altered the composition of their food purchases by switching to cheaper items, the demand for these items increased and inflated their price more than the rate of inflation in more expensive foods. For example, from 1967 to 1974 , the price of hamburger increased by 898 while that of sirloin 51 advanced by only $60 \%$. Grains, which are an important component of low-income diets, exhibited larger than average price increases due to crop failures and foreign purchases as well as increases in domestic demand. The poor, who are already consuming the lowest cost items, have few substitution options. Some have suggested that the poor are responding by eating less and/or eating pet food not intended for hu52

man consumption. These charges are practically impossible to

${ }^{51_{U}}$.S. Senate, Select Committee on Nutrition and Human Needs, Panel on Nutrition and Special Groups, National Nutrition Policy Study: Report and Recomendations - VIII, (Washington, D.C.: U.S. Government Printing Office, 1974l, p. 19.

52 Ibid., p. 20 . 
document.

While the "poor person's price index" has advanced sharply, these increases are reflected in the cost of the Economy Food Plan, although there may be some time lag. From March, 1973 to March, 1974 the price of the Economy Food Plan increased by 21 while the Liberal Cost Food Plan, the most expensive of USDA's five plans, increased by only 16.9\%. The cost of the Economy Food Plan is reflected, with some lag, in food stamp allocations. Table IV compares increases in per capita monthly food stamp bonuses with increases in the CPI, increases in the BLS" cost of food at home" component of the CPI, and with changes in average monthly payments per recipient under the AFDC program. Table IV reveals that food stamp bonuses have outpaced inflation and were nearly three times greater than increases in AFDC payments. Despite this rapid rate of increase, it is possible that the absolute level of bonus payments is inadequate as many critics contend. While President Ford attempted to reduce food stamp bonuses through raising the price of stamps to many participants, Congress has overwhelmingly rejected this policy. In sum, bonuses under the Food stamp Program have increased rapidly and are likely to continue to do so given the depth of congressional support. Charges that the program has failed to keep pace with inflation are not substantiated by the data.

53 Ibia.

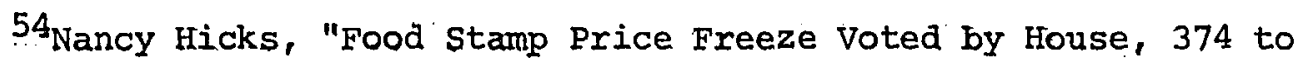
38," The New York Times, (February 5, 1975), p. 1 . Nancy Hicks, "Senate, 76-8, Votes Freeze in Price of Food Stamps," The New York Times, (February 6, 1975), p. 1 . 
RATES OF CHANGE IN THE CONSUMER PRICE INDEX, THE PRICE OF FOOD AT HOME INDEX, FOOD STAMP BONUSES AND AFDC PAYMENTS, F. Y. 1971-1974

\begin{tabular}{|c|c|c|c|c|c|}
\hline & & Fisca & 1 Year & & Perc \\
\hline & 1971 & 1972 & 1973 & 1974 & Chan \\
\hline $\begin{array}{l}\text { onsumex Price Index } \\
1967=100 \text { ) }\end{array}$ & 119.0 & 123.3 & 128.2 & 139.7 & 17 \\
\hline $\begin{array}{l}\text { cice of Food at Home } \\
\text { adex } \text { of }(1967=100)\end{array}$ & 114.6 & 118.8 & 128.6 & 153.9 & 34 \\
\hline $\begin{array}{l}\text { ean Monthly Food Stamp } \\
\text { onus per Recipient }\end{array}$ & $\$ 13.40$ & $\$ 13.50$ & $\$ 14.50$ & $\$ 19.36$ & 44 \\
\hline in Monthly AFDC pay- & $\$ 49.65$ & $\$ 51.65$ & $\$ 54.10$ & $\$ 56.95$ & 5 \\
\hline
\end{tabular}

1

Monthly Labor Review, XCIV, 8, (August, 1971), pp. 104-106;

$\mathrm{XCV}, 6$, (June, 1972), pp. 94-96; XCVI, 4, (April, 1973), pp. 110-

112; XCVII, 1, (January, 1974), pp. 110-112; XCVIII, I, (January, 1975), p. 113.

2 U.S. Department of Agriculture, Food and Nutrition Service, Food Stamp Program: Statistical Summary of Operations, June, 1971, 1972, 1973, and 1974, mimeos.

${ }^{3}$ U.S. Senate, Select Committee on Nutrition and Human Needs, National Nutrition Rolicy study: Report and Recommenäations -- VIII, (Washington, D.C.: U.S. Government Printing Office, June, 1974), p. 45. Figures are for December of the years indicated. 
Many critics of the Food Stamp Rrogram have accused the USDA of footdragging in expanding program participation. There has been a large leap in the number of program participants: in July, 1970 nearly 7,000,000 individuals received food stamps -- by January, 1975 $17,000,000$ were benefitting from the program. ${ }^{55}$ Despite this growth, it is estimated that less than $40 \%$ of the eligible are reached. Unlike public housing programs which have long waiting lists of eligible households that can not be accomodated, the Food stamp program is open-ended. All those who are certified as eligible may receive benefits. Thus critics view participation in the program as low and blame the lack of response, in part, on inadequate publicity for the program. Critics claim that many potential recipients are simply unaware that they are eligible. While it may be the case that publicity has been ineffective, the failure of eligible households to perceive that they qualify for benefits may also be due to the complexity of the formula for calculating net income for food stamps. Even official estimates of the number of eligible are extremely rough because the incidence of permissable deductions in various income

55

Ibid.

U.S. Department of Agriculture, Food and Nutrition Service, "Food Stamp Program: Statistical Summary of Operations, July, 1971," (April 6, 1972), mimeo.

${ }^{56}$ Gary W. Bickel and Maurice MacDonald, "participation Rates in the Food Stamp Program: Estimated Levels for 1974, by State, : in U.S. Senate, Select Committee on Nutrition and Huran Needs; Repcrt on Nutrition and Special Groups, Appendix B to Part I $\rightarrow$ Food Stamps, (Washington, D.C.: U.S. Government Rrinting Office, 1975).

57"Food Stamp Fund Freed by Judge," The New York Times, (October 14, 1974), p. 19 . 
classes is essentially unknown.

Court decisions, compelling more extensive outreach efforts to bring new households into the program, tend to substantiate the charge of footdragging. Judge Miles Lord, a federal district court judge in Minneapolis, held in October, 1974 that Agriculture Secretary Earl Butz and the USDA had failed to comply with the outreach provisions of the 1971 Amendments to the Food Stamp Act. In his ruling, Judge Lord concluded,

Congress intended outreach action, but inaction at both the state and federal level was what actually took place. (Butz's) response to the Congressional. directive, when viewed in its totality, is fairly described as a total failure on his part to do what Congress clearly intended him to do. 58

Judge Lord also noted that from April, 1972 to June, 1973 the number of persons receiving federal food assistance actually declined becar :e increases in the Food Stamp Program were more than offset by decreases in the Commodities Distribution Program. The USDA did not challenge 59

the accuracy of the data in the suit.

The USDA has exhibited a lack of enthusiasm for its own program uncharacteristic of a bureaucracy. Analysts of bureaucratic behavior have emphsized the tendency of officials to expand and protect their domain. In contrast, for several years, spokesmen for the USDA sought to transfer the Food stamp Program to HEW. The USDA

58

Ibid.

${ }^{59}$ Ibid.

${ }^{60}$ Anthony Downs, Inside Bureaucracy, (Boston: Little, Brown, and Co., 1966). 
was also in favor of HR 1, a version of Nixon's Family Assistance

Plan that would have cashed out food stamps. In June, 1972 Assis-

tant Secretary of Agriculture, Richard Lyng, testified before the

Senate Select Committee on Nutrition and Human Needs. In response

to Senator Percy's suggestion that food stamp benefits be liberalized,

Lyng commented,

We in the Department of Agriculture have tried as best we can to administer this program in full cooperetion with other agencies that are perhaps more expert than we in this area -- OEO, HEW, and so on. But I think it is appropriate now ... that we begin to look at the whole problem of poverty and not try to solve that problem by simply adding more funds to the feeding program. 61

In response to Senator Percy's questions about the appropriateness of

the Food Stamp Program for the elderly indigent, Lyng replied,

It seems to me that we might be wise, as a Nation, to perhaps eliminate the high administrative costs of the Food Stamp Program in terms of elderly people. of course, the administration has been trying to move in this direction in terms of HR 1 for families as well; but, particularly for elderly people, there seems to me to be justification for a cash allowance to give them flexibility to use that cash in many ways. 62

In sum, the Food Stamp Program, which is primarily a welfare program for the urban poor, has been a misfit in a department primarily responsive to rural middle-class interests.

${ }^{61}$ U.S. Senate, Select Committee on Nutrition and Human Needs, Hearings: Nutrition and Human Needs - 1972 ‥ op. cit., pp. 675-676.

62

Ibid., p. 671 . 
In addition to the lack of official ardor for the Food stamp Program at the federal level, the program has been chronically understaffed at the state and county levels. In response to the administrative cost-sharing formula outlined above, states have attempted to keep administrative costs down by understaffing the program. Oregon is one of the many states that has followed this policy. The state food stamp office in Salem has a staff of four, precisely the same number it had when the Food Stamp Program came to Oregon as a small scale Multnomah County pilot project in 1963. Multnomah County, which had nearly 44,000 program participants in February, 1975, has one field investigator. This may be one explanation for the low official incidence of fraud. ${ }^{63}$ In July through september of 1974, typical months, no benefits in Oxegon were terminated because of failure to comply with program requirements. 64

In several states, staff shortages have resulted in long lines at food stamp offices and delays in certification which have undoubtedly discouraged potential participants. For example, all night lines at food stamp offices and one month waits for appointments prevailed in Arizona during November, 1974. 65

${ }^{63}$ Douglas Yeater, Supervisor, Issuing Section, Food Stamp Division, Department of Administrative Seryices, Multnomah County, Oregon, interview, February 7, 1975.

${ }^{64}$ Multnomah County, Oregon, Food Stamp office, "Report of Reduction/Termination of Food stamp Benefits," Form FNS-285 (9-71), (July, september, 1974l, mimeo.

65"Food Stamp Lines Abate in Arizona," The New York Times, (December 27, 1974), p. 27. 
While the lines have diminished in that state, some communities still take as long as three months to process applications and certify eligibility. 66 The new administrative cost-sharing formula, discussed above, should encourage states to more adequately staff the program but should also add to its administrative price tag.

In addition to the high transaction costs imposed on the eligible by long lines, transportation costs inhibit participation by the less mobile. Non-Public Assistance participants must travel to certification offices periodically to be certified and recertified. Furthermore, they must travel to a designated distributor to receive their stamps one to four times per month, depending on the purchase schedule selected by the household. Certification and issuing points are particularly inaccessible to those in rural areas. However, even in cities, transportation may be a serious obstacle. For example, in Multnomah County there are no certification or issuing offices west of the Willamette River. Transportation costs impose particular burdens on the elderly and disabled. While stamps are sold in some public housing projects and are mailed to a small percentage of households with severe transportation difficulties, most food stamp recipients are required to do a considerable amount of traveling. Thus the structure of the program probably inhibits participation.

66 Nancy Hicks, "Use of Food Stamps Soars as Jobless Turn to Them," The New York Times, (January 29, 1975), p. 1. 
Another program attribute associated with dampening participation is the purchase price of the stamps. Welfare advocates in Oregon opposed the switch from commodities distribution to food stamps largely on the grounds that compelling low-income households to pay for stamps (commodities were free) would discourage participa67

tion. Accumulating sufficient cash at one time to purchase stamps may require a degree of planning uncharacteristic of low-income households, many of whom have irregular incomes. Prior to 1971, participating households were required to produce their entire month's purchase payment at one time. However, since 1971, households have been offered a variable purchase option which allows them to purchase stamps in quarter-month or half-month bundles. Thus the pressure to produce one large lump sum payment has been relieved. In addition, households do not forfeit their eligibility if they fail to redeem their entire momthly allotment of ATPs. Despite this flexibility, the National Nutrition Policy Study suggests that purchase prices are too high and that the cost of stamps inhibits participation. The Study recommends a price reduction or a free stamp policy. The free stamp policy suggested by the study calls for the issuance of coupons equal to the bonus value of the stamps alone rather than the bonus plus purchase price coupon value. Bonuses could still yary with family 68 size and income, as now.

\section{7} Douglas Yeater, op. cit.

68 U.S. Senate, Select Committee on Nutrition and Human Needs, Panel of Nutrition and Special Groups; op. cit., pp. 31-33. 
Another significant impediment to participation in the Food stamp Program may be the stigma attached to the use of stamps. Gillim notes,

... perhaps the key element in the program -- the stamps themselves -- pose the greatest obstacle to a person considering participation in the program. By requiring the use of food stamps instead of money, the food stamp program publicly identifies the recipient of the subsidy at the time he buys his food -probably his largest and most conspicuous purchase. For large numbers of housewives the grocery is a center where neighbors meet. There is no privacy at the checkout counter. Many sensitive persons must refuse to enter the program rather than suffer the embarrassment of being forced to pay with stamps and thereby reveal their financial difficulties before people they know. 69

Willard Renkin, Multnomah County Food Stamp Coordinator, concurs that the psychic costs of the program, significantly discourage participation and are particularly severe for the elderly.

Some of the stigma attached to stamps is being reduced due to recent efforts of labor unions to inform unemployed and striking members of program benefits and to urge them to take advantage of them. The Wall Street Journal recently printed excerpts of union publicity designed to increase the acceptability of food stamps to workers. An union official was quoted as saying, "Workers in need have a right to stamps. When they're working our members pay taxes so others can

${ }^{69}$ Marion Hamilton Gillim, "An Economic Analysis of Federal Food Subsidies," The Economics of Federal Subsidy Programs: Part 8 -- Selected Subsidies, U.S. Congress, Joint Economic Comittee, subcommittee on Priorities and Economy in Government, (Washington, D.C.: U.S. Government Printing Office, 1974), p. 1080.

${ }^{70}$ Willard Renkin; op. cit. 
have food stamps." 71 . Efforts to reach non-Public Assistance households are starting to pay-off. In January, 1975 the New York Times reported an important shift in the composition of food stamp recipients: for the first time, more than $50 \%$ of the recipients were nonPublic Assistance households. 72 Increasingly, middle-class families, squeezed by inflation, appear to be joining the program. Wall

Street Journal interviews with officials in the Massachusetts Department of Public Welfare revealed that

Food stamp applicants are incrasingly 'you and me' ... Among those applying for food stamps these days are accountants, truck drivers, government employees, factory workers, college students and even a few Massachusetts school teachers. 73

As more non-Public Assistance households join the program, the stigma attached to participation is likely to diminish.

Some critics of the Food Stamp Program are more concerned with the recipients' alleged abuse of the program than with the issue of stigma. For example, many are strongly opposed to aiding strikers. While this issue has yet to be resolved by the courts, strikers are currently receiving benefits. Assistance to college students has also been controversial. The Wall Street Journal editorialized re-

7l"Layoff Cushion: Unions Teach Jobless Members How to Get Food Stamps," The Wall Street Journal, (November 12, 1974), p. 1. op. cit.

72 Nancy Hicks. "Use of Food stamps Spars as Jobless Turn to Them,"

73 David Gumpert, "On the Dole: Because of Inflation, Midale-Class Families Join Food Stamp Rolls., "The Wall street Journal, (December 20, 1974), p. 1 . 
cently that while many genuinely needyfamilies fail to obtain food stamps " ... college students have been taking advantage of them in growing numbers, transforming a program designed to provide a balanced diet for the poor into a form of government scholarship." 74 The USDA responded to this criticism by declaring students ineligible for food stamps as of March 1, 1975 if their parents claim them as dependents for income tax purposes. ${ }^{75}$ This ruling still does not solve the "hippie commune" problem which has upset some program critics for many years. In 1971, the USDA sought to indirectly deal with the issue by denying benefits to households consisting of unrelated individuals. This policy was struck down by the courts, but the issue remains a live one. The Wall street Journal complains that food stamps are "subsidizing the diets of able-bodied young men and women who are using food stamps not to relieve poverty, but to allow them to maintain a preferred life-style."76

In addition to criticiams relating to the "unworthiness" of some recipients, there are persistent reports that food stamps are being used to purchase luxuries that few non-participants can afford. Since no record is made of items purchased with food stamps and no market

\footnotetext{
74

"Food Stamps and the Future," The Wall street Journal, (January 15, 1975), p. 10.

${ }^{75}$ Ibid.

${ }^{76}$ Ibid.
} 
survey has been conducted, it is difficult to estimate how prevalent steak is in the shopping carts of food stamp houreholds. Gillim notes that the publicness of food stamp purchases may trigger reactions to shopping patterns which are probably not characteristic of the program.

Other persons buying in the grocery, especially nonparticipants in the program, will note examples of extravagance or poor judgement in the choice of groceries bought with stamps and base their condemnation of the entire program of family food subsidies on what may be only occasional indiscretions in buying. 77

There have also been unsubstantiated reports of black markets in food stamps or food purchased with food stamps.

Concern over the operation of the Food stamp Program has grown with its share of the budget and its importance as a welfare program. The Food Stamp Program, by the second half of 1974, in effect, guaranteed an $\$ 1800$ annual income to a household of four. The concept of an income guarantee is extremely $l$ controversial and was explicity rejected by Congress in 1969 and 1970 when it considered the Family Assistance Plan and HR 1. While the food stamp guarantee is in-kind rather than in cash (and therefore more politically palatable): it is nevertheless a guaranteed income, available to intact families, households of unrelated individuals, households without children, and the working poor who haye been regulated out of most cash Public Assistance programs. Strong Congressional support for the program has probably

77 Marion Hamilton Gillim, op. cit. 
been aided by the fact that the program has never been discussed in terms of an income guarantee; instead it has been yiewed as a response to the popular "hunger issue".

In his analysis of the politics of the Family Assistance Plan Moynihan notes :

All of the parties to the dispute within the administration, and presumably most of those observing it from outside regarded the establishment of a guararteed income as a profound departure from existing practice. Some were for it, some against: alli agreed it would constitute a quantum change. And yet this was not quite the "reality". The Food Stamp Program, was, in essence, a universal system of income support for the working poor. 78

The distinction between an "incremental" change and a "quantum leap forward" is much in the eye of the beholder ... The general observation may be made that in retrospect programs such as food stamps will often be seen to have involved major changes in policy which were obscured at the time because the start-up costs of the program were small and because it was not presented as anything of extraordinary import. 79

The growing importance of food stamps as an income support mechanism is suggested by Table IV which reveals that food stamp benefits have been increasing much more rapidly than benefits under AFDC, the major cash program for the non-elderly poor. Table IV shows that while the average food stamp bonus per recipient increased by $44 \%$ from F.Y. 1971-1974, the average monthly per capita AFDC payment regis-

78

Daniel F. Moynihan, The Politics of a Guaranteed Income: The Nixon Administration and the Family Assistance Plan, (New York: Vintage Books, 1973), p. 175 .

79 .

Ibia. 
tered a gain of only 15\%. While semi-annual updates of food stamp schedules are required, updates of state Public Assistance schedules are not. Table $\mathrm{V}$ indicates the relationship between food stamp and AFDC payments for the U.S., Oregon, the five highest AFDC banefit states and the five lowest AFDC benefit states. Table $V$ reveals that food stamps have become a major component of the welfare package. In some states with low AFDC payments, food stamp benefits now exceed cash benefits. The National Nutrition Policy Study viewed this trend with some alarm. It commented:

The dramatic increases in the cost of the Food stamp program do not alter the fact that they move us in a direction all thoughtful students of income maintenance long ago recognized as unwise. If food stamp benefits improve apace with welfare inoreases that is one thing. But we are now seeing food stamp benefits increase in place of welfare or other forms of cash support, and that is a wholly different -- and unacceptable -- matter. 80

While recommending the casking out of food stamps, the study assessed this as politically unrealistic and turned its attention to program modifications, some of which have been discussed above.

The political popularity of the Food stamp Program may be viewed as evidence of the existence of "goods specific" utility interdependence. The public has been willing to support a large in-kind income transfer program during the same time period when new cash transfer program s were rejected (the Family Assistance Plan and HR 1) and when per recipient benefits under AFDe, an old cash program, have

80 U.S. Senate, Select Committee on Nutrition and Human Needs, Panel on Nutrition and Special Groups, op. cit., p. 48. 
TABIE $V$

FOOD STAMP BONUSES AND AFDC PAYMENTS, U. S. AND SELECTED STATES ${ }^{1}$

Mean Monthly

Food Stamp

Bonus Per

Mean Monthly

AFDC Payment

Food Stamp

Recipient

Per Recipient

Bonus as

January, 1974

November, 1973

Percent of

AFDC Payment

\begin{tabular}{lccr} 
U. S. & $\$ 19.54$ & $\$ 56.86$ & 35 \\
Oregon & $\$ 21.08$ & $\$ 68.17$ & 31 \\
Five Lowest AFDC States & & \\
\hline Mississippi & $\$ 17.58$ & $\$ 14.45$ & 129 \\
Alabama & $\$ 23.27$ & $\$ 21.61$ & 105 \\
South Carolina & $\$ 24.03$ & $\$ 24.34$ & 100 \\
Louisiana & $\$ 23.99$ & $\$ 25.25$ & 96 \\
Texas & $\$ 21.01$ & $\$ 30.77$ & 68
\end{tabular}

Five Highest AFDC States

$\begin{array}{llll}\text { Wisconsin } & \$ 14.58 & \$ 93.89 & 16\end{array}$

$\begin{array}{llll}\text { Minnesota } & \$ 17.63 & \$ 82.78 & 22\end{array}$

$\begin{array}{llll}\text { New York } & \$ 12.91 & \$ 81.34 & 16\end{array}$

$\begin{array}{llll}\text { Massachusetts } & \$ 13.83 & \$ 79.83 & 18\end{array}$

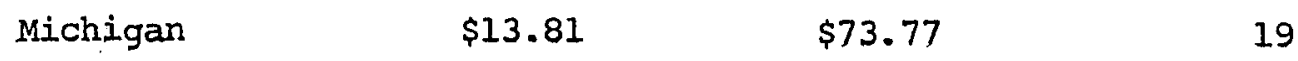

1

Source: U.S. Senate, Select Comittee on.Nutrition and.Human Needs, National Nutrition Policy Study: Report and Recommendations -VIII, (Washington, D.C.: U.S. Government Printing office, June, 1974), pp. $42-43$. 
been relatively stagnant. Unlike housing programs, the ability of the market to supply food to the low-income has never been questioned. However, like housing programs, certain assumptions:about the inelasticity of the demand of poor households have been made. Underlying the Food stamp Program is the premiss that low-income families need to be induced to consume an "adequate" amount of food. It is feared that general income transfers would be "wasted" by the recipients from the point of view of the taxpayer. As with low-income housing programs, the efficacy of the food stamp strategy depends on the shape of taxpayer and potential recipient's preferences, on the relative administrative costs of various transfer schemes, and on the degree to which consumption patterns of program participants differ from those of nonparticipants of equivalent income. These issues will be examined in an empirical investigation of the Food Stamp Program in MuItnomah County. 
CHAPTER IV

CRITERIA FOR THE EVALUATION OF IN-KIND TRANSFERS

Hypotheses to be Tested

The preceding chapters on the development of the utility interdependence framework in welfare theory and on the current operation of two major in-kind transfer programs indicate some fertile territory for empirical investigation. In-kind programs are emphasized in this research because of their rapid rate of growth relative to cash transfers (Table I) and because of their current dominance of the welfare package (Table II). The strong political support for in-kind programs suggests that this transfer mode will command an even zarger share of the welfare budget in the immediate future. Given the increasing importance of transfers in-kind, the many untested and frequently unstated premisses underlying this transfer mode demand explanation.

In-kind transfers assume that the "natural" consumption patterns of intended program beneficiaries impose external costs on the larger community, that these external costs are diminished by transfers inkind which induce alterations in consumption patterns, and that the costs associated with such transfers do not exceed the sum of private and social benefits deriyed from them. In the vocabulary of welfare theory, in-kind transfers reflect a belief in the existence of "goodsspecific" utility interdependence and a conviction that special incentives are required to persuade the poor to purchase a socially accep- 
table level of basic commodities. Generalized income transfers are rejected on the grounds that the unregulated market behavior of consumers (and in some cases, of suppliers) would not maximize social utilič.

Empirical validation of these important assumptions has not been rigorously attempted. The following research gaps, vital to a proper evaluation of the efficacy of in-kind strategies need to be filled. In-kind transfers assume that the consumption patterns of the target population of intended beneficiaries are substantially altered by inkind programs, but actual comparaisons of the consumption patterns of program participants and eligible nonparticipants have been neglected. To what extent to in-kind programs succeed in altering market behavior? Private and social benefits of transfer programs are assumed to equal or exceed program costs. Is this the case? How does the magnitude of conceivabie private and social benefits compare with the market value of the transfer and the administrative and other costs of the program? In-kind transfers are expected to reach the target population. To what extent are program benefits, in fact, distributed in the manner intended by policymakers?

An empirical examination of the operation of the low-income housing and food stamp programs in Multnomah County, Oregon will serve as a vehicle for analyzing these important theoretical issues. Specifically, the equity and efficiency of in-kind transfers will be assessed by testing the following hypotheses. 
I. In-kind transfers are inefficient.

A. In-kind transfers are characterized by high administrative and participation costs.

B. In-kind transfers do not have the intended impact of significantly diminishing the external diseconomies associated with the consumption patterns of the target population.

1. Transfers generous enough to significantly alter the consumption patterns of the recipients reach $: y$ only a fraction of the eligible and thus have little impact on the consumption choices of the target population as a whole.

2. Transfers which reach a large proportion of the eligible are not generous enough to significantly alter consumption patterns.

II. In-kind transfers are inequitable. Those of similar income and demographic characteristics do not receive similar treatment.

Problems in Evaluating Public Prograns

There are numerous impediments to the effective evaluation of programs aimed at redistributing income. Many of these are a product of the political environment of welfare legislation described in chapters I and III. One problem is the tendency of public policies to have blurred objectives and multiple goals which are not clearly weighted or may eyen be in conflict with one another. For example, low-income housing programs have been simultaneously oriented 
to increasing the supply of housing and transferring income to the low-income population; goals which may call for quite different program structures. Once the goals of a particular program are identified, criteria for assessing them in the light of broader social objectives and for measuring the operation of the program in relation to its goals are required. Since there is a wide divergence of opinion as to what societal goals, in regard to income redistribution ought to be, the researcher must resort to very general standards to appraise the adequacy of public transfer programs. At a minimum, it is assumed in this work that public transfer programs strive to operate equitably and efficiently: that a program should insure the equal treatment of equals and that the societal and private benefits of a program should be maximized relative to its cost.

Even when clear criteria for evaluating programs are accepted, there are important practical problems which stem from the nature of decision-making and administration in the public sector. A serious obstacle to program assessment is the control of information by the responsible bureaucracies which have a concrete stake in concealing program flaws. Oversight by Congressional committees, the General Accounting office, and the media place limits on the capacity of public agencies to conceal or misrepresent information, but program evaluation still relies heavily on data generated in house. While explicit questions from Congressional committees or the G.A.O. do elicit explicit, if uncomfortable, responses, in many cases, it is not clear to outsiders what the key questions should be. Thus program evaluations are difficult, in practice, because evaluations by those responsible 
for programs are biased and external evaluations suffer from the control of data by insiders.

The effective evaluation of public programs is further inhibited by their non-market character. In the private sector, a firm has a strong incentive to engage in self-criticism, since failure to do so may result in a loss of profits, or, in the extreme, bankruptcy. In the public sector, the link between budget share (profits) and the efficient production of a desired good or service is obscure. The future funding of a particular program hinges more heavily on the level of past funding and on the characteristics of the political environment than it does on agency performance. In addition, as discussed above, the standards for measuring the "goodness" of a public product are far more controversial than the generally accepted index of success in the private sector, profits.

Despite these unresolved issues, a. set of criteria will be proposed for evaluating in-kind transfer programs. The criteria will be an extension and specification of standards suggested by Weisbrod for evaluating programs aimed at the redistribution of income.

Weisbrod contends that transfer programs ought to:

1. Minimize administrative costs.

2. Maximize "target efficiency" (maximize the participation of those in the target group and minimize the participation of those outside the target group?

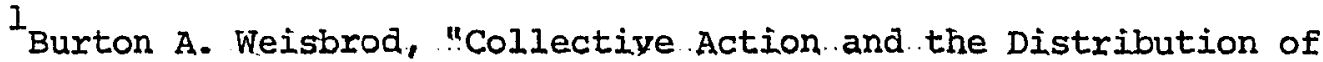
Income," in Public Expenditures and Policy Analysis, Robext H. Haveman and Julius Margolis (editorsl, CChicago: Markham Publishing Company, 1970), pp. 117-141. 
3. Maximize allocative efficiency (minimize substitution effects).

4. Maximize nondemeaning benefits (minimize the "stigma" associated with transfer programs).

5. Maximize the utility of the taxpayers and the transfer recipients.

6. Maximize program flexibility over time.

Weisbrod notes that these criteria are frequently in conflict with one another and difficult to operationalize. For example, programs which are highly accurate in channeling benefits to the target group may require large administrative costs, depending on how the target group is defined. In-kind transfers, which are intended to have substitution effects, involve trade-offs with allocative efficiency. Some of the empirical dimensions of these trade-offs will be analyzed with the aid of a model for evaluating in-kind transfers. This model, presented below, operationalizes most of Weisbrod's criteria. It will be employed in two empirical investigations of the strength of the case for in-kind transfers.

\section{A Model for Evaluating In-Kind Transfers}

A model for evaluating in-kind income transfer programs appears in Figure 2. The model proposes methods for measuring key concepts identified in the theoretical discussion of "goods-specific" utility interdependence in Chapter II and in Weisbrod's work discussed in this chapter. 


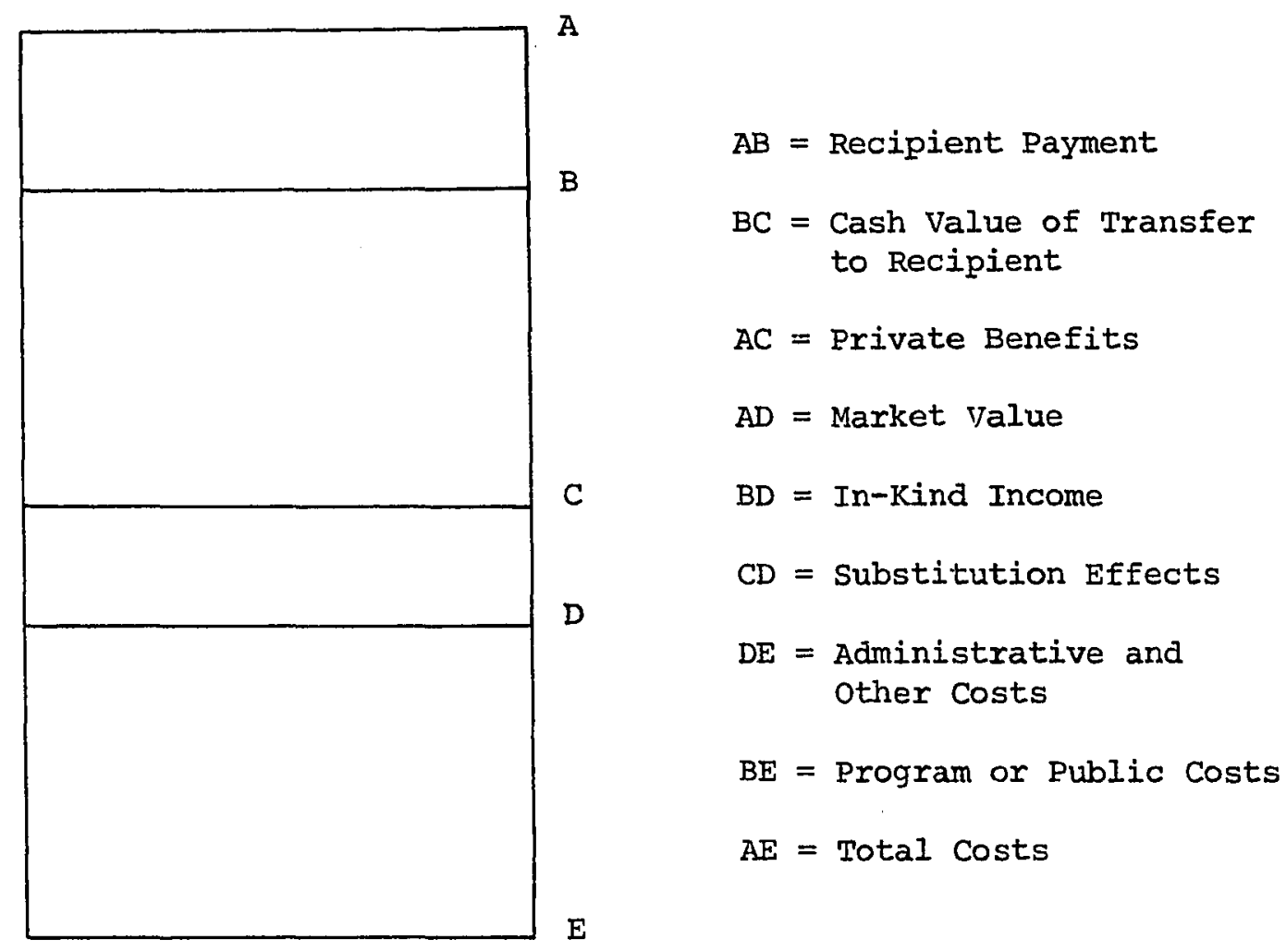

Figure 2. A model for evaluating in-kind transfers.

All of the following definitions refer to value per recipient.

$A B=$ Recipient Payment, if any.

$B C=$ Cash Value of the In-Kind Transfer to the Recipient.

$A C=$ Cash Value of the In-Kind Good or Service to the Recipient or Private Benefits $=A B+B C$. AC is defined as the recipient's point of indifference between an in-kind and a cash transfer or what the recipient would have been willing to pay for the in-kind good or service, if he had received cash.

$\mathrm{AD}=$ Market Value of the in-kind good or service or its unsubsidized cash value. $A D$ may be equal to or greater than $A C$, depending upon the recipient's marginal propensity to consume the good or service in question.

$\mathrm{BD}=$ In-Kind Income provided by the transfer program. 
$\mathrm{CD}=$ Substitution Effects or the utility loss suffered by the recipient from the distortion of his consumption pattern resulting from the acceptance of an in-kind transfer. $C D=0$ when the marginal propensity of the recipient to congume the good or service in question is equal to or greater than the consumption level demanded by the in-kind program.

$\mathrm{DE}=$ Administrative and Other Program Costs.

$\mathrm{BE}=\mathrm{BD}+\mathrm{DE}=\underline{\text { Program }}$ or Public Costs or the sum of the market value of the transfer minus the recipient's contribution and the other costs of making the transfer.

$\mathrm{AE}=\mathrm{AB}+\mathrm{BE}=$ Total Costs.

Figure 2 includes social costs, but it does not contain an estimate of social benefits. While theoretically social benefits are measurable, in practice, it is not feasible to directly assess the external benefits of transfer programs from existing data. However, De Salvo has suggested an indirect method of estimating what the minimal externalbenefits must be for a program to "pay-off" from a benefitcost viewpoint. He suggests that social or external benefits must, at a minimum, equal total costs minus the cash value of the in-kind good or service to the recipient. ${ }^{2}$ Equation 1 contains De Salvo's conceptualization of minimum required social benefits (SB) in terms of Eigure 2 .

$$
\text { (1) } \quad \mathrm{SB}^{\mathrm{min}}=\mathrm{AE}-\mathrm{AC}
$$

This equation permits the comparison of programs on the basis of the minimum external benefits that they require to warrant their costs and suggests that programs with high administratiye costs require com-

${ }^{2}$ Joseph S. De Salyo, "A Methodology for Evaluating Housing Programs," Journal of Reginnal Science, XI, 2 (August, 1971), pp. 173-185. 
mensurately large external benefits to be deemed efficient.

While De Salyo's approach considers the size of social benefits required to cover costs, his methodology does not measure actual social benefits. An indirect attempt will be made to approximate the actual social benefits of in-kind programs through an analysis of substitution effects and participation rates. The discussion of utility interdependence in Chapter II suggested that in-kind transfers are evidence of the taxpayers' desire to transfer particular goods and services rather than general income. If this is the case, then the magnitude of substitution effects, or the degree to which in-kind transfers increase the consumption of particular goods or services, may be used as a proxy for external benefits. While the receipient suffers disutility from altering his consumption patterns, presumably taxpayers experience increments in utility related to the size of such alterations.

The effect of changes in consumption patterns or substitution effects on program nonparticipants is linked not only to the size of the alterations in expenditures but to the extent to which the desired effects prevail among the target population. If a program induces large substitution effects but reaches only a small fraction of the eligible, then it is unlikely to significantly diminish the negative externalities associated with the consumption patterns of the target population as a whole. For example, installing $5 \%$ of the occupants of substandard housing in high quality units may have large effects on the consumption patterns of those selected, but it is unlikely to significantly alter the impact of substandard housing on the non- 
poor because $95 \%$ of the target population remains in substandard accomodations. In an effort to incorporate these key variables in an estimate of social benefits, Equation (2) will be used to approximate the social or external benefits of in-kind programs.

$$
\text { (2) } \mathrm{SB}=\mathrm{CD} \times \mathrm{PR}
$$

where $C D$ equals the substitution effects, if any, elicited by the transfer (Figure $2 \%$ ) and $\mathrm{PR}$ is a participation ratio" defined as the number of program participants divided by the number of program eligible. Equation (2) indicates that if there are no substitution effects then there are no external benefits. This is a result of the stringent assumption that in-kind transfers are motivated solely by the desire to increase the consumption of particular commodities rather than to transfer income in general.

While participation ratios are important in the assessment of external benefits, they may also be viewed as indicators of supply bottlenecks and/or participation costs. Low participation ratios suggest that there is a limited supply of a transfer or that the costs of participation outweigh its benefits from the intended beneficiary's perspective. In programs with elastic supply but low participation ratios, the preceding chapters suggest that the following factors are important in the potential recipient's participation decision.

1. In-kind transfers may have information, transaction, and transportation costs which exceed the value of the transfer to the recipient. For example, there may be excessive red tape, complex eligiblity requirements, inadequate program publicity and/or inconveniently located vendors. 
2. The disutility of altering preferred consumption patterns required by the in-kind transfer may exceed its value to the recipient. (In Figure 2, CD may be greater than $\mathrm{BC}$ ).

3. The high psychic costs associated with some programs which publicly identify and stigmatize the recipient may exceed the value of the transfer to the recipient.

4. The transfer may not be available in the geographic area in which some of the eligible reside.

Thus participation ratios may be important indicators of participation costs as well as a component in the evaluation of social benefits. .

The model presented in Figure 2 and Equations (1) and (2)

will be employed in an empirical evaluation of the low-income housing and Food Stamp programs in Multnomah County, Oregon. These programs will be evaluated exclusively in the context of their equity and efficiency as soods-specific income transfer mechanisms. Other functions that thes a programs may serve will not be dealth with in this research. Chapters V and VI contain the empirical results for housing and food stamps respectively, while Chapter VII relaies these results to the proposed hypothese and the theoretical framework of utility interdependence. 
AN EMPIRICAL INVESTIGATION OF IN-KIND TRANSFERS: THE CASE OF LOWINCONE HOUSING

In this chapter, the model presented in Chapter IV will be applied to the low-income housing programs managed by the Housing Authow. rity of Portland (HAP). All HAP data are for April 1, 1972 to March 31, 1973, (HAP fiscal year 1972) unless otherwise noted. (This unconventional fiscal year, beginning in April, is the HUD accounting period and does not conform to accounting periads in other federal departments.) HAP's jurisdiction extends over Multnomah County, which includes the City of Portland. As of 1972, HAP's inventory included 1400 conventional public housing units, 526 Turnkey public housing units, and approximately 1660 privately owned, leased units which HAP sublet to low-income households.

\section{Program Costs}

The first step in evaluating housing programs as an income transfex strategy. is to assess program costs or BE in Figure 2 of Chapter IV. For conventional and Turnkey structures, owned by HAP, program costs are the sum of 1) capital costs, 2l operating subsidies and 3) tax subsidies. For leased units, program costs consist solely of operating subsidies.

1) Capital Costs. Tables VI and VII list the original development costs of HAP is conventional and Turnkey units and the conversion of these costs into constant 1972 dollars. Table VIII con- 
TABIE VI

DEVELOPMENT COSTS, CONVENTIONAL PUBLIC HOUSING, PORTLAND, OREGON, 1938-1972 1

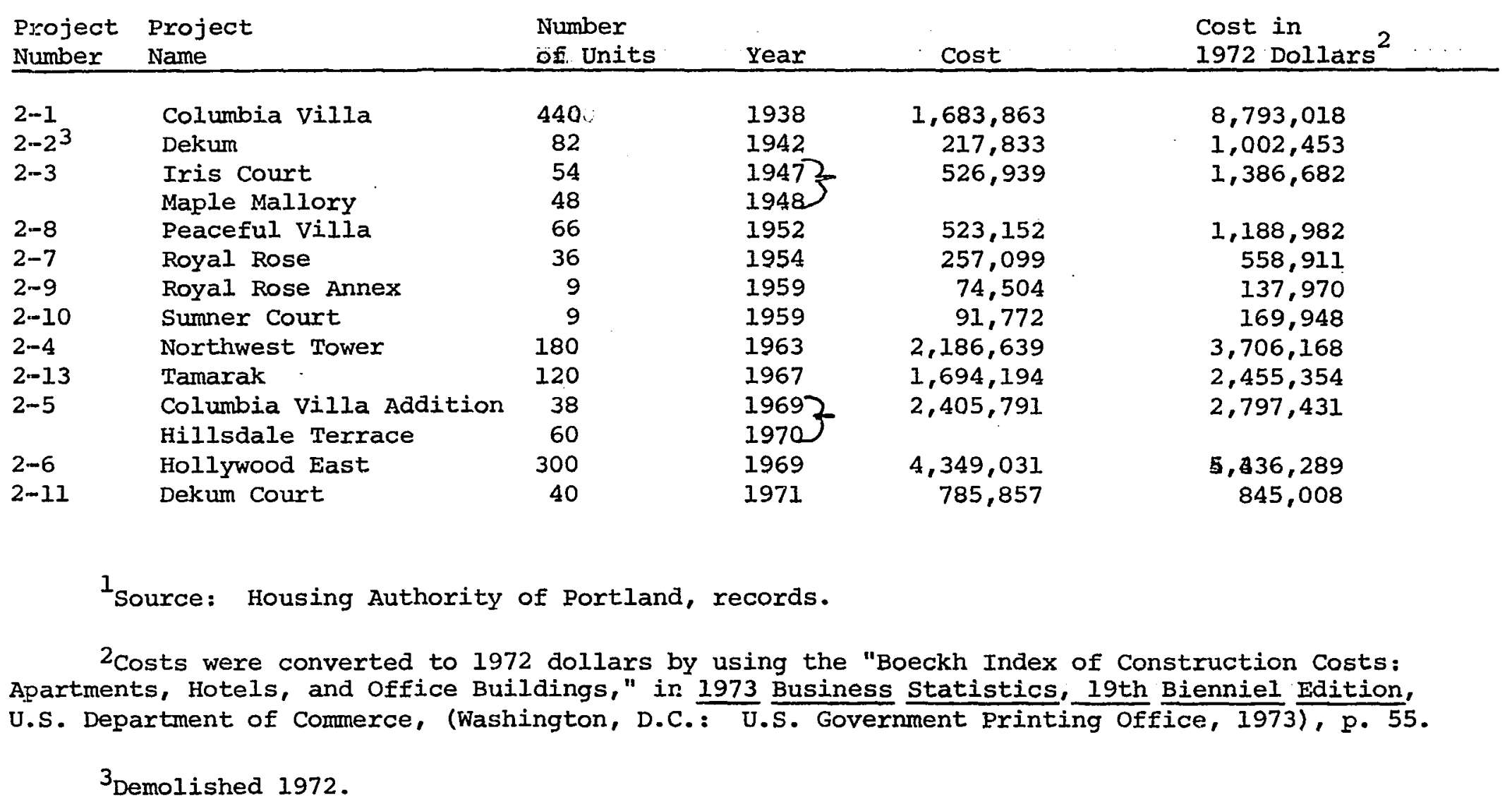


TABLE VII

DEVELORMENT COSTS, TURNKEY PUBLIC HOUSING, PORTLAND, OREGON, $1938-1972^{1}$

\begin{tabular}{|c|c|c|c|c|c|}
\hline $\begin{array}{l}\text { Project } \\
\text { Nwaber }\end{array}$ & $\begin{array}{l}\text { Project } \\
\text { Name } \\
\end{array}$ & $\begin{array}{l}\text { Number } \\
\text { of Units }\end{array}$ & Year & Cost & $\begin{array}{l}\text { Cost in } \\
1972 \text { Dollars } \\
\end{array}$ \\
\hline $2-14$ & Dahlke Manor & 115 & 1971 & $2,262,370$ & $2,432,656$ \\
\hline $2 \cdot-15$ & Holgate House & 80 & 1971 & $1,556,767$ & $1,673,943$ \\
\hline $2-16$ & Sellwood Center & 112 & 1971 & $1,809,195$ & $1,945,371$ \\
\hline $2-17$ & Schrunk-Riverview Tower & 118 & 1971 & $2,109,599$ & $2,268,386$ \\
\hline $2-18$ & Williams Plaza & 101 & 1971 & $1,927,051$ & $2,072,098$ \\
\hline
\end{tabular}

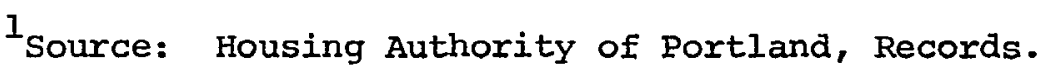

${ }^{2}$ Costs were converted to 1972 dollars by using the "Boeckh Index of Construction Costs: Apartments, Hotels, and Office Buildings," in 1973 Business Statistics, 19th Bienniel Edition, U.S. Department of Commerce, (Washington, D.C.: U.S. Government Printing Office, 1973), p. 55. 
TABLE VIII

MODERNIZATION COSTS, CONVENTIONAI RUBLIC HOUSING, 1969-1972 (in 1972 dollarsi ${ }^{1}$

Project Number

Project Name

Modernization Costs

2

Columbia villa

$1,587,470$

$2-3$

Iris Court and

100,678

Maple Mallory

$2-4$

Northwest Towers

195,260

$2-7$

Royal Rose

203,261

$2-8$

Peaceful Villa

88,457

$2-9$

Royal Rose Annex

29,067

$2-10$

Sumner Court

24,614

${ }^{1}$ Source: Housing Authority of Portland, Records. Costs were converted to 1972 dollars by using the "Boeckh Index of Construction Costs: Apartments, Hotels, and Office Buildings," in 1973 Business Statistics, 19th Bienniel Edition, U.S. Department of Commerce, (Washington, D.C.: U.S. Government Printing Office, 1973), p. 55. 
tains HAP's expenditures for modernization as of 1972. The mean capital expenditure per unit (original plus modernization cost) of conventional public housing was $\$ 20,719.99$ while Turnkey units averaged $\$ 19,757.52$ (Table IX, Column 1). While Turnkey units were slightly less expensive than conventional units, they are not of comparable size. Conventional units averaged 1.46 bedrooms, while Turnkey units average 0.66 bedrooms. In Portland, all of the Turnkey projects have been built for the elderly and consist exclusively of efficiency and one-bedroom units. Portland development costs are very close to average national per unit costs for low-rent public housing of $\$ 20,967.1$

The key controversial issue in estimating capital costs is the selection of the discount rate or the social opportunity cost of transferring resources from the private to the public sector. Few analysts would quarrel with the contention that public projects compete with private endeavors for resources and that consequently, opportunity, rather than actual capital, costs are relevant in assessing public prorgrams. However, the choice of a specific discount rate is more problematic. The discount rate is crucial because project cost estimates are very sensitive to the rate employed. Table IX shows the annual per unit capital subsidies required for conyentional and Turnkey units at four different discount rates. Most economists would probably opt for a rate between 5 and 7 percent. Smolensky,

$1_{U}$.S. Department of Housing and Urban Development; 1972 HUD Statistical Yearbook, (Washington, D.C.: U.S. Government Printing Office, 1974), p. 163 . 
TABIE IX

CAPITAL SUBSIDIES, CONVENTIONAI AND TURNKEY PUBLIC HOUSING, PORTIAND, OREGON, 1972

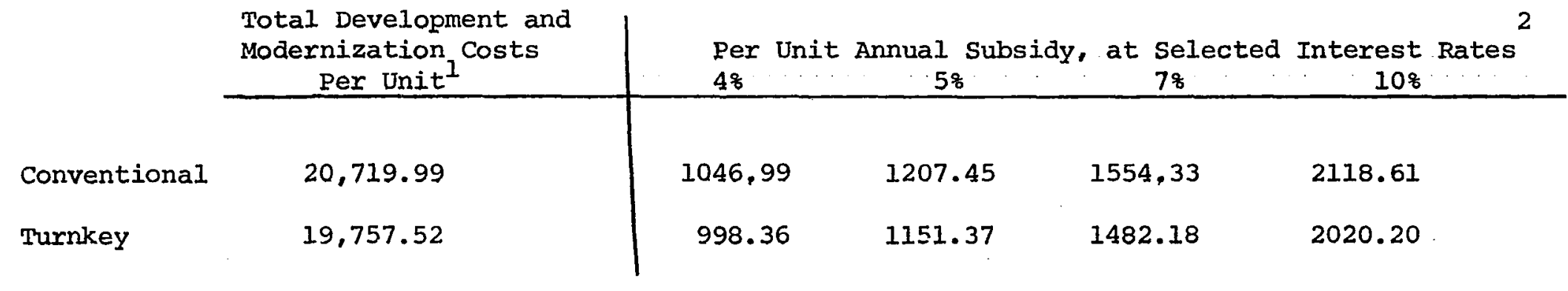

1

Derived from Tables VI, VII and VIII. "Costs in 1972 Dollars" and "Modernization Costs" were summed and divided by the total number of units.

2 The annual per unit subsidy was calculated by solving for $s$ in the following formula:

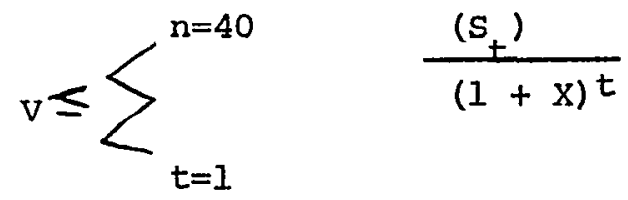

where $\mathrm{V}=$ per unit development and modernization costs in 1972 dollars, $\mathrm{S}=$ annual subsidy per unit and $\mathrm{x}=$ interest rate. The formula is suggested in Eugene Smolensky, "Public Housing or Income Supplements -- The Economics of Housing for the Poor, " American Institute of Planners Iournal, (March, 1968), p. 95. 
in a calculation of the capital costs of public housing, used $5 \%$ which reflected the average yield of FHA bonds from 1952-1964, the period of his study. 2 An extremely conservative estimate of the social rate of discount is 4\%, the average yield of Aaa bonds from 1938-1972, the period of HAP's investment. ${ }^{3}$ At the opposite extreme, Baumol makes a strong case that the corporate income tax structure requires investments in the private sector to yield at a rate twice as large as the rate of interest to be profitable. Baumol argues that given the competition between public and private projects, public projects ought to yield at roughly double the interest rate on government bonds or $10 \%$ However, Baumol assumes that the entire private sector is corporate in structure and does not account for the favorable treatment of certain forms of corporate debt. Table Ix reflects the range of viewpoints on the question of interest rate and reveals that moving from a discount rate of $4 \%$ to $10 \%$ more than doubles the estimated annual per unit subsidy. In this study, $7 \%$ will be used as the discount rate as a reasonable reflection of the sharp climb in interest rates in recent years and as a partial concession to Baumol's argument.

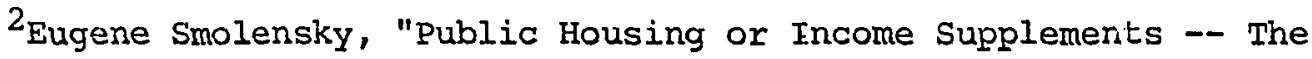
Economics of Housing for the poor," American Institute of Planners Journal, (March, 1968), p. 96.

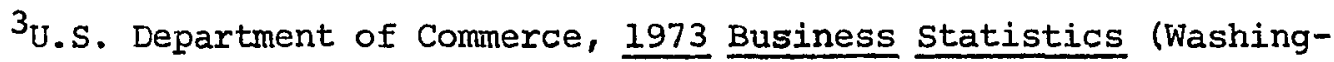
ton, D.C.: U.S. Government Printing Office, 1973), p. 105.

4illiam J. Baumol, "On the social Rate of Discount," The American Review, LVIII, (September, 1968), pp. 788-802. 
In the calculation of capital costs in Table IX, a building life of 40 years was assumed -- this is standard for public housing projects. In addition, it was assumed that capital costs are completely subsidized by the federal government. (Smolensky assumed that a small portion of tenant rents was used to defray capital costs. This was the case in 1966, the year of his study, but since the late 60's tenant rents have not been sufficient to cover even operating expenditures.)

2. Operating Subsidies. Tables X, XI, and XII contain the monthly operating receipts, expenditures and deficits for conventional, Turnkey and leased units, respectively. Per unit operating deficits in conventional units, $(\$ 24.21)$, are over twice as large as those in Turnkey units, (\$10.42), primarily because of higher maintenance and administrative expenses in conventional units. These higher costs are largely attributable to the much older average age of conventional units (Tables VI and VII) and the fact that many conventional units serve families with children who present HAP with greater "problems" than the elderly residents of the Turnkey projects. 5 Nationally, monthly per unit subsidies for LHA owned units (includes conventional and Turnkey) were $\$ 13.46 .6$

Monthly receipts, expenditures, and deficits for leased units, (Table XII), are not directly comparable with those for projects owned

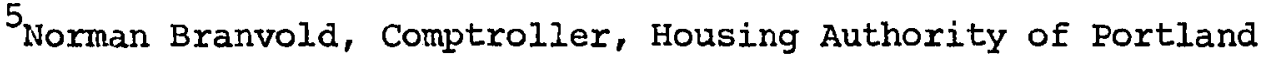
Interview. p. 133.

6U.S. Department of Housing and Urban Development, op. cit.,
} 
TABLE X

ORERATING RECEIPTS AND EXPENDITURES, CONYENTIONAL PUBLIC HOUSING, PORTLAND, OREGON, APRIL 1, 1972 -- MARCH: 31, $1973^{1}$

PUM

Total

(Per Unit Month) $\cdots(16 ; 986$ PUMs)

Operating Receipts

Tenant Rents

33.07

$561,656,00$

Other Income

7.66

$130,151.00$

TOTAL OPERATING

RECEIPTS

$60.73 \quad 691,807.00$

Operating Expenditures

Administrative

14.66

$249,035.00$

Tenant Services

1.46

$24,878,00$

utilities

14.92

$253,415.00$

Ordinary Maintenance

23.90

$406,027.00$

and Operations

General Expenses ${ }^{2}$

9.95

$169,033.00$

Non-routine Expenses

.05

850.00

TOTAL OPERATING EXPENDITURES

(Operating Deficit)

\begin{tabular}{ll}
64.94 & $1,103,238.00$ \\
\hline$(24.21)$ & $(411,431.00)$ \\
\hline
\end{tabular}

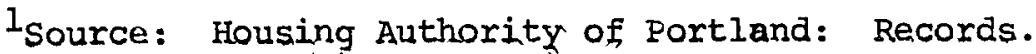

${ }^{2}$ General Expenses include employee fringe benefits. The separation of fringe benefits from administrative expenditures is mandated. by the HUD accounting format and does not reflect a decision of the local housing authority. 
TABIE XI

ORERATING RECETPTS AND EXPENDITURES, TURNKEY PUBLIC HOUSING, PORTLEND, OREGON, APRIL 1, 1972 - MARCH 31, $1973^{1}$

PUM

Total

(Per Unit Month) $\cdots(6 ; 312$ PUMs $)$

Operating Receipts

Tenant Rents

32.98

$208,142.00$

Other Income

5.05

$31,888.00$

TOTAL OPERATING

RECEIPTS

\begin{tabular}{rr}
5.05 & $31,888.00$ \\
\hline$\quad 38.03$ & $240,030.00$ \\
\hline
\end{tabular}

Operating Expenaitures

Administrative

10.15

$64,023.00$

Tenant Services

.75

$4,706.00$

Utilities

14.69

$92,744.00$

Ordinary Maintenance and Operations

16.33

$103,059.00$

General Expenses ${ }^{2}$

6.50

$41,018.00$

Non-routine Expenses

.03

167.00

TOTAL OPERATING

EXPENDITURES

(Operating Deficit)

$\begin{array}{r}.03 \\ \hline 48.45 \\ \hline(10.42) \\ \hline\end{array}$

${ }^{1}$ Source: Housing Authority of Rortland: Records.

2

General Expenses include employee fringe benefits. The separation of fringe benefits from administrative expenditures is mandated by the HUD accounting format and does not reflect a decision c: the local housing authority: 
OPERATING RECEIPTS AND EXPENDITURES, LEASED LOW-INCOME HOUSING, PORTLAND, OREGON, APRIL 1, 1972 -- MARCH 31, $1973^{1}$

PUM

Total

(Per Unit Month) … $(19 ; 962$ PUMs)

Operating Receipts

$$
\begin{aligned}
& \text { Tenant Rents } \\
& \text { Other Income } \\
& \text { TOTAL OPERATING } \\
& \text { RECEIPTS }
\end{aligned}
$$$$
20.17
$$$$
3.85
$$$$
402,657.00
$$$$
76,926.00
$$

$\begin{array}{r}24.02 \quad 479.583 .00 \\ \hline\end{array}$

Operating Expenditures

$$
\begin{aligned}
& \text { Administrative } \\
& \text { Tenant Services } \\
& \text { Utilities } \\
& \text { Ordinary Maintenance } \\
& \text { and Operations } \\
& \text { General Expense } \\
& \text { Non-Routine Expense }
\end{aligned}
$$

15.68

.78

.26

TOTAL OPERATING EXPENDITURES

Landlord Lease Payments

(Deficit) TOTAL EXPENDITURES

\begin{tabular}{cc}
24.89 & $496,857.00$ \\
\hline 103.87 & $2,073,436.00$ \\
\hline 128.76 & $2,570,293.00$ \\
\hline$(104.74)$ & $(2,090,710.00)$ \\
\hline
\end{tabular}

ISource: Housing Authority of Portland: Records.

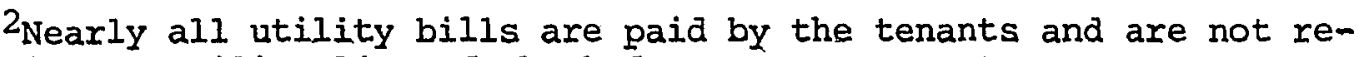
flected in the utility line of the budget. Howeyer, tenant rents are considerably below those in conventional and turnkey public housing because expected utility expenditures are considered when setting rents.

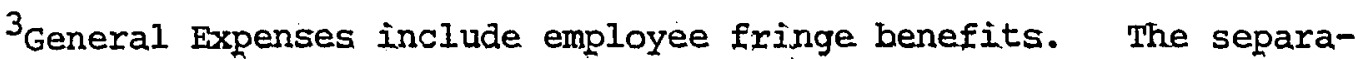
tion of fringe benefits from administrative expenditures is mandated by HUD accounting format and does not reflect a decision of the local housing authority. 
by. HAR. The large monthly per unit deficit of \$1Q4.74 largely reflects HAP's payments to private landlords. Tenant rents and utility expenditures by HAP are lower than those in public housing because tenants in leased units pay utility vendors directly. Their rental payments to the housing authority are adjusted downward to reflect this arrangement. Table XIII summarizes the operating subsidies required for low-income units on a monthly and annual basis.

3. Tax Subsidies. Housing authorities do not pay property taxes on the structures that they own. In lieu of property tax, they pay $10 \%$ of shelter rent (tenant rents minus utility payments) to local governments. For example, in 1972, in conventional units, HAP collected $\$ 561,656$ in rent and paid $\$ 253,415$ for utilities (Table $x$ ). In lieu of taxes, HAP paid $10 \%$ of the difference or $\$ 30,824$ to local tax districts. Table XIV indicates that $\mathrm{n}:=$ 's payments in lielu of taxes are substantially lower than full property taxes would be on their structures. In 1972, this tax subsidy, the difference between full property taxes and actual HAP payments, amounted to $\$ 298.95$ per unit per year for conventional units and $\$ 435.39$ per unit per year for Turnkey units. The larger tax subsidy for Turnkey units reflects the fact that Turnkey units are newer and consequently haye a considerably higher per unit valuation. While the assessed yalue per unit in conventional projects was $\$ 11,213$, Turnkey units were assessed at $\$ 15,814$. Since HAP rental receipts are related to tenant income, not unit value, the spread between $10 z$ of shelter rent and full property tax is greater for more valuable units. 
TABLE XIII

OPERATING SUBSIDIES, CONVENTIONAL AND TURNKEY PUBLIC HOUSING, LEASED LOW-INCOME IEEASED HOUSING, PORTLAND, OREGON, APRIL I, 1972 -- MARCH $31,1973^{1}$

Per Unit Per Unit Unit

Month (\$) Annual (\$) Months . Total (\$)

$\begin{array}{lrrrr}\text { Conventional } & 24.21 & 290.52 & 16,986 & 411,431 \\ \text { Turnkey } & 10.42 & 125.04 & 6,312 & 65,687 \\ \text { Leased } & 104.74 & 1,256.88 & 19,962 & 2,090,710\end{array}$

1 Derived from Table $X, X I, X I I$ 
TABLE XIV

PROPERTY TAX SUBSIDIES, CONVENTIONAL AND TURNKEY PUBLIC HOUSING, PORTALAND, OREGON, APRIL 1, 1972 -MARCH $31,1973^{1}$

Payment in Lieu of Taxes

Approximate Full Real Property Taxes

(@ 28.92 per thousand) 2

(TAX SUBSIDY)

Tax Subsidy Per Unit Month

Annual Tax Subsidy Per Unit

\begin{tabular}{cc}
$\begin{array}{c}\text { Conventional } \\
\text { (Assessed Valuation } \\
\$ 15,697,820)\end{array}$ & $\begin{array}{c}\text { Turnkey } \\
(\text { Assessed Valuation } \\
\$ 8,317,940)\end{array}$ \\
\hline $30,824.01$ & $11,539.83$ \\
\hline & \\
\hline $453,980.96$ & $240,554.82$ \\
\hline & $(229,014.99)$ \\
\hline
\end{tabular}

24.91

36.28

298.95

435.39

1Source: Housing Authority of Portland: Records

2

Taxing Authority

Multnomah County City of Portland

Port of Portland

School District \#1

Multnomah IED

Portland Community College

TOTAL
Tax Rate

$$
\begin{array}{r}
5.08 \\
8.21 \\
1.02 \\
9.15 \\
4.72 \\
.74 \\
\hline 28.92
\end{array}
$$


Summary of Program Costs. Table XV summarizes the total monthly and annual per unit costs of HAP owned and leased units, assuming a $7 \%$ discount rate. In terms of the model in Figure 2, BE or program costs are $\$ 2143.80$ per year for conventional units, $\$ 2042.64$ for Turnkey units, and $\$ 1256.88$ for leased units. $A B$ or annual tenant rent equals \$396.84 for conventional units and $\$ 395.76$ for Turnkey units. In leased units, $A B$ equals the sum of rent and utility payments to private vendors or $\$ 422.04$ per year. $A E$ or total annual per unit costs are $\$ 2540.64$ for conventional units, $\$ 2438.40$ for Turnkey units, and $\$ 1678.92$ for leased units. Thus leased housing is $34 \%$ less expensive than conventional units and $31 \%$ less expensive than Turnkey units. As noted above, direct comparisons between Turnkey and conventional units are distorted by differences in average anit size, age and type of occupant. However, leased units serve roughly the same population as conventional public housing and are comparable or slightly larger in size.

These results for conventional and Turnkey units are very close tc those reported recently by Solomon for Boston. Using a similarly inclusive concept of costs, solomon found total annual costs in conventional units were $\$ 2586$ while those in Turnkey unit; averaged \$2430. However, he found annual costs in leased units averaged $\$ 2484$, substantially greates than those calculated for portland. 7

7 Arthur P. Solomon, Housing the Urban Roor, (Cambridge: the MIT Rress, 1974l, p. 149. 
TABIE XV

HOUSING SUBSIDIES PER UNIT, CONVENTIONAL, TURNKEY AND LEASED LOW-INCOME HOUSING, PORTLAND, OREGON APRIL 1, 1972 -- MARCH $31,1973^{1}$

\begin{tabular}{lccc|cc|c|c} 
& $\begin{array}{c}\text { Monthly } \\
\text { Capital } \\
\text { Subsidy }\end{array}$ & $\begin{array}{c}\text { Monthly } \\
\text { Operating } \\
\text { Subsidy }\end{array}$ & $\begin{array}{c}\text { Monthly } \\
\text { Property } \\
\text { Tax Subsidy }\end{array}$ & \multicolumn{2}{|c|}{$\begin{array}{c}\text { Total Subsidy } \\
\text { Month }\end{array}$} & $\begin{array}{c}\text { Annual } \\
\text { Tenant } \\
\text { Rent }\end{array}$ & $\begin{array}{c}\text { Total Annual } \\
\text { Cost } \\
\text { Per Unit }\end{array}$ \\
\hline Conventional & $129.53^{*}$ & 24.21 & 24.91 & 178.65 & 2143.80 & 396.84 & 2540.64 \\
Turnkey & $123.52^{*}$ & 10.42 & 36.28 & 170.22 & 2042.64 & 395.76 & 2438.40 \\
Leased & 0 & 104.74 & 0 & 104.74 & 1256.88 & $422.04 * *$ & 1678.92
\end{tabular}

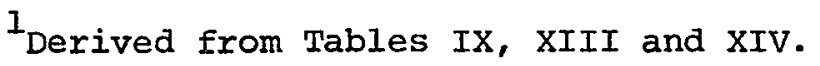

*Assumes a discount rate of $7 \%$.

**Includes utility payments to private vendors. 
Part of the difference is attributable to laxger tenant rent payments in Boston -- average ienant contributions exceeded those in Rortland by $\$ 300$ per year. This difference may be due to the greater affluence of Boston public housing tenants and/or to the higher rent levels that prevail there. In 1970, median contract rent in Portland was $\$ 97$ while in Boston it was $\$ 111 .^{8}$ Most of the remaining difference between the Portland and Boston results for leased housing is a function of Solomon's inclusion of accelerated depreciation in his assessment of program costs. Accelerated depreciation was not included in the cost calculations for Portland leased housing because of the judgement that these tax benefits are available to all private landlords, not just to those leasing to HAP. As such, these costs should not be charged exclusively to the low-income housing program.

\section{Market Value}

The market value of public housing units, $\mathrm{AD}$ in Figure 2, is difficult to determine because in many respects public housing is a unique product without a private sector counterpart. Housing authorities facilitate the provision of social services to their tenants in addition to furnishing housing. For example, HAP has arranged for public health nurses, counselors, and food stamp vendors to visit large HAP projects. other services are also delivered directly to HAP residents because of

81975 the US Factbook, The American Almanac, The Statistical Abstract of the U.S. as prepared by the Bureau of the Census, Department of Commerce, (New York: Grosset and Dunlap, 1975), pp. 895, 915. 
HAP's cooperation with social service agencies. Wile these services are undoubtedly important to their recipients, HAP's primary objective is to provide a substitute for private housing. While the non-housing services may enhance the value of public housing, the stigma that many low-income households associate with living in public projects and the neighborhood effects of the concentration of low-income households may reduce the value of publicly:! owned units below the "market price" of physically comparable units.

Table XVI contains several approaches to pricing public housing as well as the median rent for the county and the SMSA. The first set of suggested market rents were proposed by HUD when requested to estimate the market value of public housing by the subcomittee on Fiscal Policy of the Joint Economic Committee. HUD proposed using its rent standards which include utilities for Relocation Assistance. In Multnomah County, these standards were $\$ 136$ for a one-bedroom unit and $\$ 172$ for a two-bedroom unit. When compared with the median gross rent in the SMSA, which includes some affluent suburban developments, the market values propesed by HUD appear inflated. It is not credible that the "market" would price public housing units substantially above the \$125 for a one-bedroom unit and the \$152 for a two-bedroom unit prevailing in the SMSA. Table XVI indicates that another possible approach to estimating the market value of public housing units is to use the maximum rent limits established for low-income leased units in the county as proxies. Leased units must qualify as standard and pass HAP inspection. In addition; they are intended as an alternative to puiplic housing for a comparable population. In constant 1972 dollars, the 
TABLE XVI

SELECTED METHODS OF ESTIMATING THE MARKET VALUE OF PUBLIC HOUSING UNITS, PORTLAND, OREGON, $1972^{1}$

Proposed Market Rents

1) HUD Max. Gross Rent Relocation Assistance Payments, Multnomah Co. ${ }^{2}$
HUD Max. Gross Fair Market Rents,

2) HUD Max. Gross Fair Market Rents,
Existing Leased Housing, Multnomah County ${ }^{3}$

3) Median Gross Rent in Public Housing Census Tracts ${ }^{4}$

Conventional Turnkey

Median Gross Rent Multnomah County 4 Median Gross Rent Portland SMSA 4
Monthly Rent

1 Bedrm. 2 Bedrm.

172

117

110

120

120

125
133 no 2-bedrm. units

145

152

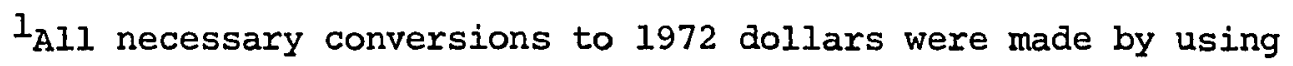
the Shelter Rent Component of the Consumer Price Index in Handbook of Labor Statistics, 1973, U.S. Department of Labor, Bureau of Labor Statistics, (Washington, D.C.: U.S. Government Printing Office, 1974), p. 299.

2U.S. Congress, Joint Economic Committee, Subcommittee on Fiscal Policy, Studies in Public Welfare, Paper No. 15: Welfare in the 70's: A National Study of Benefits Available in 100 Iocal Areas, (Washington, D.C.: U.S. Government Printing Office, 1974), p. 16.

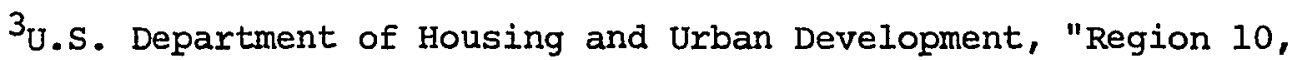
Fair Market Rents (Maximum Gross Rent Payable) for Existing Section 23 Leased Housing," Federal Register, 39, 131, July 8, 1974.

${ }^{4}$ U.S. Bureau of the Census, Census of Population and Housing; 1970, Census Tracts, Final Report PHC(1)-165, Portland, Oregon-Washington SMSA, (Washington, D.C.: U.S. Government Printing office, 1972). Median rents in public housing tracts were weighted by the number of public housing units appearing in those tracts. Median rents were assumed to be for one-bedroom units since the median number of persons in rental units $=2$. 2-bedroom rents were estimated by using the average differential in the HUD schedules between 1 and 2 bedroom units. 
maximums established for existing leased housing were $\$ 117$ for a onebedroom unit and $\$ 137$ for a twombedroom unit.

Another approach is to assume that public housing is comparable to the median rental unit in the census tracts in which public housing is located. This technique yielded a market value of $\$ 110$ and $\$ 120$ respectively for conventional and Turnkey one-bedroom units. This methodology appears to successfully pick up the fact that Turnkey units, on the average, are newer and are located in "better" neighborhoods than are conventional units -- and hence should be more valuable. Two-bedroom conventional units are assigned a market value of $\$ 133$, using the same technique. (There are no two-bedroom Turnkey units). These rents are close to the median gross rents for the county. As such, they seem quite generous to public housing. For lack of a more direct measure, these median rents in the relevant census tracts will be employed as proxies for the market value of conventional and Turnkey units, $A D$ in Figure 2.

Estimating the market value of leased units is much less convoluted since private landlords presumably demand a "market price" for their units from HAP. Table XVII indicates that leased units have a mean monthly gross rent of $\$ 107.63$ for a one-bedroom unit and $\$ 128.85$ for a two-bedroom unit. Utility and maintenance expenditures have been added to the payments to landlords to expedite comparisons with HAP owned units which include these outlays. 
TABLE XVII

ESTIMATED MARKET VALUE, LOW-INCOME LEASED HOUSING, RORTLAND, OREGON,1972

Average Landlord Rent ${ }^{1}$

Utilities $^{2}$

Maintenance ${ }^{3}$

TOTAL ESTIMATED GROSS

MONTHLY MARKET RENT
1 Bedroom Unit for Elderly
87.54

15.00

5.09

107.63
2 Bedroom Unit

\subsection{6}

15.00

5.09

5.09

128.85

1 Housing Authority of Portland, "Leased Housing Status Report," mimeo.

2 Utilities are not included in landlord payments. Utility expenditures in conventional and turnkey units, as shown in Tables XIII and XIV, plus the small utility expenditures for leased housing in Table XV were used to approximate utility expenditures in leased low income housing.

3 Maintenance in low-income leased housing is the responsibility of the housing authority. Maintenance expenditures are from Table XV. 
Private Benefits: The Cash Value of Public Housing to Tenants

The calculation of substitution effects, $\mathrm{CD}$ in Figure 2, or the degree to which in-kind subsidies alter the recipients' preferred consumption patterns, requires an estimate of what tenants' would be likely to expend on housing, if their subsidy were in cash. Table XVIII contains mean gross monthly rental expenditures of households by family size and income class. While the source of these statistics, the Bureau of Labor Statistics' Consumer Expenditure Survey of 1960-61, is quite dated, no adequate alternative was located. Therefore, the rent and utility components of the Consumer Price Index were used to 9 convert gross rents into 1972 prices. A new BLS survey has recently been completed but the results will not be available until 1976.10

Two checks were made on the accuracy of projecting housing consumption expenditures for low-income households from data nearly a decade old. These checks revealed that there appears to be astonishingly little error in the methodology. A survey of low-income households prepared for HAP in 1972 found that, of those eligible for public housing, median monthly rent was $\$ 86$, median family size was 1.8 and median annual income was below $\$ 30000^{11}$ Table XXI indicates that a

9U.S...Department of Labor, Bureau of Labor Statistics, Handbook of Labor Statistics 1973, (Washington, D.C.: U.S. Goyernment Printing Office, 1974), p. 299 .

10 Bruce Hanchett, Assistant Regional Director, Bureau of Labor Statistics, to Judith A. Barmack, Letter, October 3, 1974.

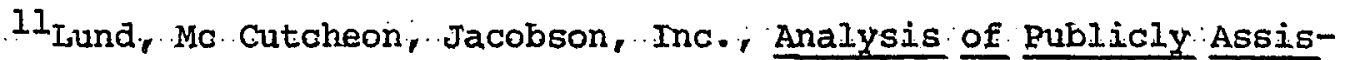
ted Low Income Family Housing Requirements Portland, Oxegon, 197. Report prepared for the Housing Authority of Portland, January, 1972, PF. T4-T8. 
TABIE XVIII

ESTIMATED GROSS MONTHLY RENT BY FAMILY SIZE AND INCOME ILASS, URBAN UNITED STATES, $1972^{1}$

\begin{tabular}{|c|c|c|c|c|c|c|c|}
\hline Family Size & $\begin{array}{l}1000- \\
1999 \\
\end{array}$ & $\begin{array}{l}\text { Estim } \\
2000- \\
2999 \\
\end{array}$ & $\begin{array}{l}\text { d Gross } \\
3000- \\
3999 \\
\end{array}$ & $\begin{array}{c}\text { Monthly Rent } \\
4000- \\
4999 \\
\end{array}$ & $\begin{array}{l}\text { by Money } \\
5000- \\
5999 \\
\end{array}$ & $\begin{array}{c}\text { Income } \\
6000- \\
6999 \\
\end{array}$ & $\begin{array}{c}\text { After Taxes } \\
7500- \\
9999 \\
\end{array}$ \\
\hline 1 & 63 & 67 & 87 & 82 & 100 & 119 & 117 \\
\hline 2 & 64 & 85 & 92 & 101 & 108 & 110 & 133 \\
\hline 3 & 57 & 77 & 88 & 99 & 109 & 122 & 140 \\
\hline 4 & * & 75 & 78 & 97 & 101 & 113 & 133 \\
\hline 5 & * & 78 & 89 & 94 & 110 & 120 & 123 \\
\hline $6+$ & * & 55 & 83 & 93 & 107 & 113 & 138 \\
\hline
\end{tabular}

$I_{U} . S$. Department of Labor, Bureau of Labor Statistics, Consumer Expenditures and Income: Cross-Classification of Family eharacteristics, Urban United States, 1960-61, Supplement 2, Part A to BLS Report 237-38, (Washington, D.C.: u.S. Government Printing Office, 1965), Tables 11a-1lg. 1972 gross rents (includes utilities) were estimated by applying the rent and utility components of the Consumer Price Index to the rent and utility statistics from the 1960-61 survey. The Consumer Frice Index and its components is from U.S. Department of Labor, Bureau of Labor Statistics, Handbook of Labor Statistics, 1973 (Washington, D.C.: U.S. Government Printing Office, 1974), pp. $299-304$.

*Small sample size in these categories made results unreliable. 
household of two with income between $\$ 2000-2999$ was expected to have a 1972 rent of $\$ 85$ - nearly identical to that reported in the HAP survey. A second verification of the methodology was made by comparing Table XVIII with county data from the 1970 census. In 1970 the mean gross rent of households below the poverty line in Multnomah county was $\$ 83$ ( $\$ 90$ in 1972 dollars)..$^{12}$ This is also quite close to the projected rents for low-income households in Table XVIII. While these attemps at independent verification of the methodology suggest that large errors are improbable, it would be desirable to revise Table XVIII, as necessary, when the new BLS survey becomes available. Table XVIII will be used to estimate the cash value of in-kind housing transfers to the tenant, $\mathrm{AC}$ in terms of Figure 2.

\section{Participation Rates}

In Chapter IV it was suggested that a major issue in assessing the social benefits of in-kind subsidies is the extent to which the transfers reach the target population. Table XIX contains HAP's 1972 eligibility limts for leased and public housing. Table XX contains the distribution of households (includes families and single individuals) in the county by household size and cash income at the time of the 1970 census. Table XXI, showing the number of county households eligible for HAP programs, was derived by applying HAP's eligibility

12 U.S. Bureau of the Census, Census of Population: 1970, General Social and Economic Characteristics, Final Report, PC (1)-39 Ore$\frac{\bar{g}}{\text { gon, }}$ (Washington, D.C.: U.S. Government Printing office, 1972), p. 262. 
TABLE XIX

1

HOUSING AUTHORITY OF PORTLAND, ELIGIBIEITY LIMITS, 1972

\begin{tabular}{|c|c|c|c|c|c|}
\hline $\begin{array}{l}\text { Family } \\
\text { Size }\end{array}$ & $\begin{array}{l}\text { Elderly (E) or } \\
\text { Nonelderly (NE) }\end{array}$ & $\begin{array}{r}\text { Maximum A } \\
\text { Admission } \\
\text { Gross } \\
\end{array}$ & $\begin{array}{l}\text { nual Income for } \\
\text { Public Housing } \\
\text { Net for Rent }\end{array}$ & $\begin{array}{c}\text { Maximum Ar } \\
\text { Admission } \\
\text { Gross }\end{array}$ & $\begin{array}{l}\text { nual Income for } \\
\text { Leased Housing } \\
\text { Net for Rent }\end{array}$ \\
\hline $\begin{array}{l}1 \\
i\end{array}$ & $E$ & 3778 & 3400 & 4722 & 4250 \\
\hline 1 & $\mathrm{NE}$ & 3579 & 3400 & 4474 & 4250 \\
\hline 2 & $E$ & 4556 & 3800 & 5611 & 4750 \\
\hline 2 & $\mathrm{NE}$ & 4316 & 3800 & 5316 & 4750 \\
\hline 3 & $\mathrm{NE}$ & 5368 & 4500 & 6553 & 5625 \\
\hline 4 & $\mathrm{NE}$ & 6211 & 5000 & 7526 & 6250 \\
\hline 5 & NE & 7053 & 5500 & 8500 & 6875 \\
\hline 6 & $\mathrm{NE}$ & 7789 & 5900 & 9342 & 7375 \\
\hline 7 & $\mathrm{NE}$ & 8526 & 6300 & 10184 & 7875 \\
\hline
\end{tabular}

1

Source: Housing Authority of Portland, Records. 
TABIE XX

ANNUAL MONEY INCOME BY HOUSEHOLD SIZE, MULTNOMAH COUNTY, OREGON, $1970^{1}$

\begin{tabular}{|c|c|c|c|c|c|c|c|c|c|}
\hline $\begin{array}{l}\text { Household } \\
\text { Size }\end{array}$ & 2000 & $\begin{array}{l}2000- \\
2999\end{array}$ & $\begin{array}{l}\text { Number } \\
3000- \\
4999\end{array}$ & $\begin{array}{l}\text { Of Hous } \\
5000- \\
6999\end{array}$ & $\begin{array}{c}\text { eholds } \\
7000- \\
9999\end{array}$ & $\begin{array}{l}\text { Income } \\
\text { I0000- } \\
\text { 14999. }\end{array}$ & $\begin{array}{l}15000- \\
24999\end{array}$ & $25000+$ & Total \\
\hline 1 & 17323 & 7293 & 9333 & 6977 & 5905 & 2884 & 748 & 374 & 50837 \\
\hline 2 & 4656 & 4378 & 9325 & 8840 & 12891 & 14801 & 7067 & 2188 & 64146 \\
\hline 3 & 1506 & 1022 & 2522 & 3618 & 7093 & 8914 & 5077 & 1231 & 30983 \\
\hline 4 & 859 & 642 & 2309 & 2054 & 5512 & 8974 & 4940 & 1388 & 24369 \\
\hline 5 & 383 & 305 & 718 & 969 & 3557 & 5415 & 3130 & 871 & 15348 \\
\hline \multirow[t]{2}{*}{$6+$} & 350 & 254 & 716 & 928 & 2778 & 4884 & 3066 & 978 & 13954 \\
\hline & & & & & & & & TOTAL & 199637 \\
\hline
\end{tabular}

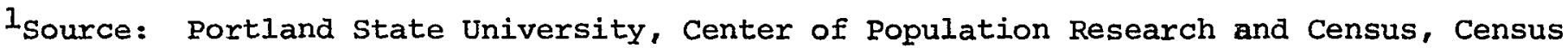
Tract Records, 1970. Income refers to 1969 income as reported in the 1970 Census of Population. Income is the algebraic sum of wage and salary income, nonfarm net self-employment income, farm net self-employment income, Social security or railroad retirement income, public assistance or welfare income, and all other income. Income does not include the value of income "in-kind." 
TABLE XXI

ESTIMATED NUMBER OF HOUSEHOLDS ELIGIBIE FOR LOW-INCOME PUBLIC OR LEASED HOUSING, BY HOUSEHOLD SIZE AND INCOME, MULTNOMAH COUNTY, OREGON, $1972^{1}$

\begin{tabular}{|c|c|c|c|c|c|c|}
\hline \multirow{2}{*}{$\begin{array}{l}\text { Household } \\
\text { Size }\end{array}$} & \multicolumn{5}{|c|}{ Number of Households by Income } & \multirow[b]{2}{*}{ Total } \\
\hline & 2000 & $2000-2999$ & $3000-4999$ & $5000-6999$ & $7000-9999$ & \\
\hline 1 & 17323 & 7293 & 7466 & 0 & 0 & 32082 \\
\hline 2 & 4556 & 4378 & 9325 & 2033 & 0 & 20392 \\
\hline 3 & 1506 & i022 & 2522 & 2822 & 0 & 7872 \\
\hline 4 & 859 & 642 & 1309 & 2054 & 992 & 5856 \\
\hline 5 & 383 & 305 & 718 & 969 & 1779 & 4154 \\
\hline $6+$ & 350 & 254 & 716 & 928 & 2167 & 4415 \\
\hline & & & & & TOTAL & 74771 \\
\hline
\end{tabular}

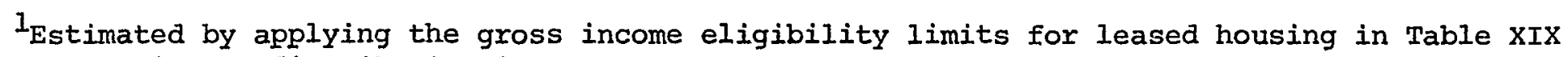
to the county income distribution in Table $x x$. It was assumed that the households in a given income class are evenly distributed across that class. For household sizes 1 and 2, eligibility limits half way between those for elderly and nonelderly households were employed. 
limits (Table XIX) to the distribution of households in Table XX. Assuming that the distribution of households by income and size did not change radically between 1970 and 1972, Table XXI indicates that approximately 74,771 households in Multnomah County were eligible for HAP assistance. Since HAP had only 3511 units in 1972, only about 58 of the target population was accomodated. Table XXI reveals that $37 \%$ of the households in the county were eligible for HAP programs. Since other HUD programs, such as 235 and 236, have more generous eligiblity limits, an extremely large proportion of the county population is eligible for some form of housing subsidi. : Table XXII compares HAP's eligibility limits with the 1972 poverty thresholds established by the Census Bureau. HAP eligibility limits are far above the official poverty lines. For example, HAP's eligibility limits for leaseã units are 468 to $136 \%$ above the Census thresholds -- depending upon household size. In addition, HAP's limits are more generous for elderly households, while Census poverty lines are higher for the nonelderly. The Census Bureau's differentiation between elderly and non-eldexly in setting poverty lines is based on the definition of poverty as three times the cost of a minimal diet; elderly households are assumed to require less food than younger households. HAP's standards reflect the view that the housing needs of the elderly than are those of younger households of comparable size. 
TABIE XXII

IIOW-INCOME TIRESHOLDS FOR NONFARM HOUSEHOLDS BY HOUSEHOLD SIZE, U.S., 1972 AND HOUSING AUTHORITY OF PORTIAND LOW-INCOME HOUSING ELIGIBILITY LIMITS

\begin{tabular}{|c|c|c|c|c|}
\hline $\begin{array}{l}\text { Household } \\
\text { Size }\end{array}$ & $\begin{array}{l}\text { Elderly (E) ox } \\
\text { Nonelderly (NE) }\end{array}$ & $\begin{array}{l}\text { Low-Income } \\
\text { Threshold }\end{array}$ & $\begin{array}{l}\text { Max. Income } \\
\text { Public Housing } 2\end{array}$ & $\begin{array}{l}\text { Max. Income } \\
\text { Leased } \mathrm{Hsg}^{2}\end{array}$ \\
\hline 1 & $\mathrm{NE}$ & 2168 & 3579 & 4474 \\
\hline 1 & $\mathbf{E}$ & 2005 & 3778 & 4722 \\
\hline 2 & $\mathrm{NE}$ & 2808 & 4316 & 5316 \\
\hline 2 & $E$ & 2530 & 4556 & 5611 \\
\hline 3 & $\mathrm{NE}$ & 3339 & 5368 & 6533 \\
\hline 4 & $\mathrm{NE}$ & 4275 & 6211 & 7526 \\
\hline 5 & NE & 5044 & 7053 & 8500 \\
\hline 6 & $\mathrm{NE}$ & 5673 & 7789 & 9342 \\
\hline 7 or more & $\mathrm{NE}$ & 6983 & $8526 *$ & 10184 * \\
\hline
\end{tabular}

*7 person household

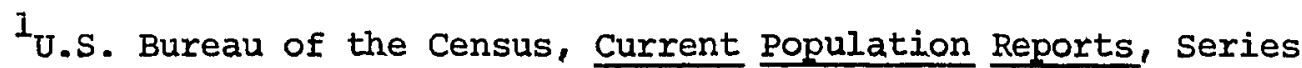
P-60, No. 91, "Characteristics of the Low-Income Population: 1972," U.S. Government Printing Office, Washington, D.C., 1973, Table A-2, p. 143.

${ }^{2}$ Maximum gross annual income for admission, Table XIX. 
Distribution of Private Benefits: Characteristics of HAP Tenants

While households far above the poverty Iine are eligible for subsidies, Table XXIII indicates that actual benefits are concentrated on extremely indigent households. The mean annual income of tenants in all of HAP's units was below $\$ 3000$ per year and virtually all of HAP's tenants receive some form of governmental cash transfer payments. Less than $3 \%$ of HAP's tenants are employed. Table XXIV reveals that the average HAP household is small, consisting of 2.22 individuals. Only $42 \%$ of the households served by HAD contain children. Benefits are heavily skewed toward the eldexly and toward households with female heads. Table Xxv shows that the median age of all HAP household heads is $65 ; 76.28$ of households are headed by women. HAP's emphasis on the elderly is clear; the 1970 Census found that of persons below the poverty line, $24 \%$ were elderly. In contrast, over $50 \%$ of HAP!s units are allocated to the elderly. HAP also has a heavy representation of non-whites relative to their presence in the county population. Table XXV indicates that $27.7 \%$ of HAP's units were occupied by non-white households. The 1970 Census counted blacks as only 48 of the population of the county and about $10 \%$ 14 of the county's poverty population.

Table XXYI contains characteristics of low-rent public housing

13 1975 the U.S. Factbook, op. cit., p. 911.

14 U.S. Bureau of the Census, op. cit., pp. 262-63; 266. 
TABLE XXIII

CHARACTERISTICS OF TENANTS: INCOME AND SOURCE OF INCOME, HOUSING AUTHORITY OF PORTLAND, $1973^{1}$

\begin{tabular}{|c|c|c|c|c|}
\hline & $\begin{array}{l}\text { Conventional } \\
\text { Public Housing }\end{array}$ & $\begin{array}{l}\text { Turnkey } \\
\text { Public Housing }\end{array}$ & $\begin{array}{l}\text { Low-Income } \\
\text { Leased Housing }\end{array}$ & $\begin{array}{l}\text { Total } \\
\text { HAP }\end{array}$ \\
\hline Number of Households & 1390 & 527 & 1594 & 3511 \\
\hline Mean Arnual Income & $\$ 2376.64^{*}$ & $\$ 2212.00$ & $\$ 2962.68$ & unavailable \\
\hline \multicolumn{5}{|l|}{$\begin{array}{l}\text { Workers per Household } \\
\text { (percent) }\end{array}$} \\
\hline None & 96.9 & 99.6 & 96.9 & 97.3 \\
\hline 1 & 3.1 & 0.4 & 3.1 & 2.7 \\
\hline 2 or more & 0.0 & 0.0 & 0.0 & 0.0 \\
\hline \multicolumn{5}{|l|}{$\begin{array}{l}\text { Cash Transfer Payments } \\
\text { (percent) }\end{array}$} \\
\hline $\mathrm{OAA}$ & 8.3 & 11.8 & 8.0 & 8.7 \\
\hline AFDC & 39.3 & 0.0 & 43.3 & 35.2 \\
\hline$A B$ & 0.8 & 2.7 & 0.9 & 1.1 \\
\hline APTD & 6.2 & 3.2 & 6.0 & 5.7 \\
\hline Other & 51.6 & 90.0 & 43.0 & 53.6 \\
\hline
\end{tabular}

*Does not include the following projects for the elderly: Northwest Tower, Hollywood East, and Peaceful villa.

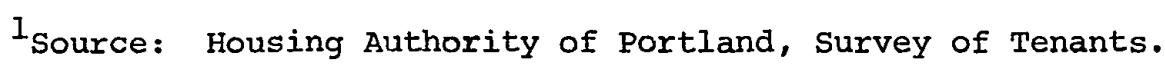


TABLE XXIV

1

CHARACTERISTICS OF TENANTS: HOUSEHOLD SIZE, HOUSING AUTHORITY OF PORTLAND, 1973

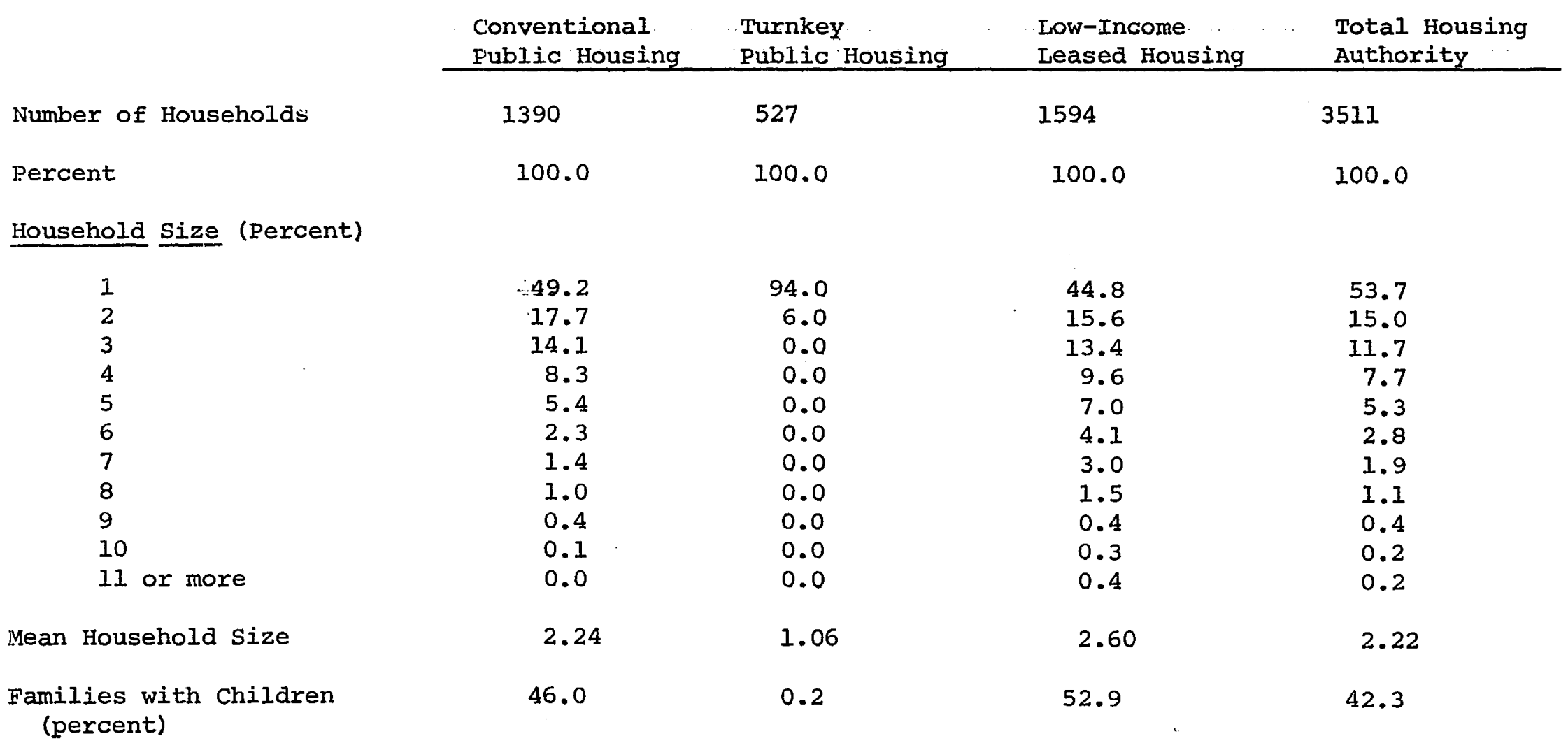

1

Source: Housing Authoirty of Portland survey of tenants. 
TABLE XXV

CHARACTERISTICS OF TENANTS: AGE, SEX, AND RACE OF HEAD, HOUSING AUTHORITY OF PORTLAND, $1973^{1}$

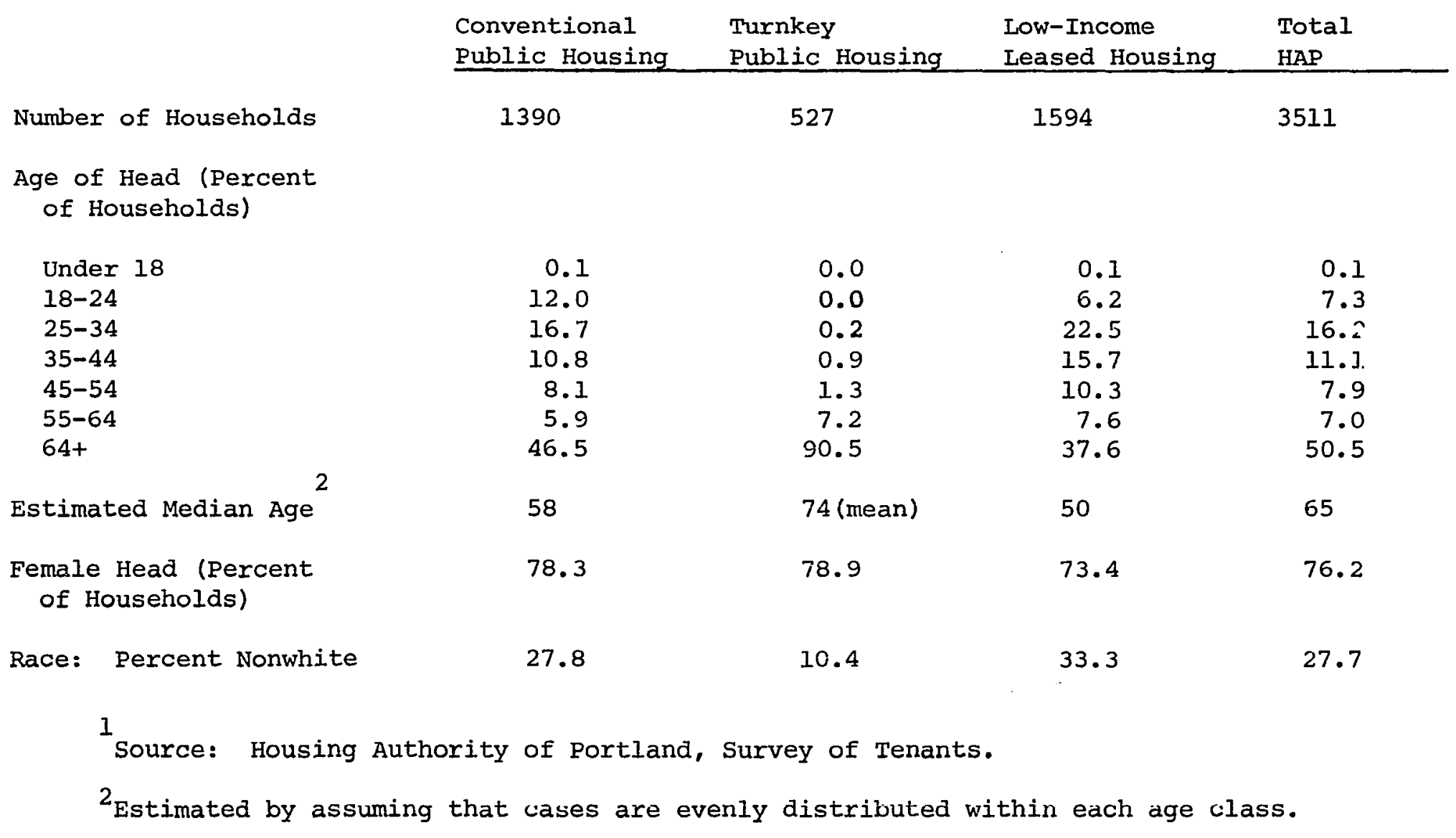


TABLE XXVI

LOW-RENT PUBLIC HOUSING, CHARACTERISTICS OF HOUSEHOIDS REEXAMINED FOR CONTINUED OCCURANCY DURING TWELVE MONTHS ENDED SEPTEMBER 30, 1972, U.S. 1

Elderly Households

135,810

100

1.65

71

35.9

$\$ 1988.00$

97
All Households

367,641

100

3.34

48

60.9

$\$ 2879.00$

75

Receiving Cash Transfer

Payments

1

U.S. Department of Housing and Urban Development, 1972 HUD Statistical Yearbook, (Washington, D.C.: U.S. Government Printing Office, 1974), Tables 108-111, pp. 121-123. 
occupants. on a national basis. As in portland, public housing benefits nation-wide are concentrated on very low income households. The median annual income for housing authority tenants in the nation was \$2879. Compared to Portland, a smaller, but still substantial, 758 of tenants receive cash transfer paymetns. However, HAP clearly serves older and smaller households. than the average public housing program. Nationally, the median age of household heads was 48, compared to 65 for HAP. The median household size, nationaily, was 3.34 while HAP's was 2.22. While nationally the percent non-white in public housing is more than double HAP's rate; most public housing is located in urban areas with substantially larger non-white populations than Multnomah County. In sum, benefits from low-income housing subsidies, both in Portland and in the nation, appear to reach: the genuinely needy. However, HAP has a strong bias in favor of the needy elderly -- perhaps reflecting the greater political palatability of projects serving a less controversial population than younger indigent households with school-age children.

\section{Evaluating Housing Subsidies}

Figures 3 and 4 contain applications of the model presented in Chapter IV to the empirical data contained in this chapter. Figure 3 demonstrates the effects of housing subsidies on an elderly couple in a one-bedroom Turnkey or leased unit. The couple is assumed to have an annual cash income of $\$ 2500$, close to the mean income for HAP residents (Table XXIII). Excergts from HAP's rent schedule appear 


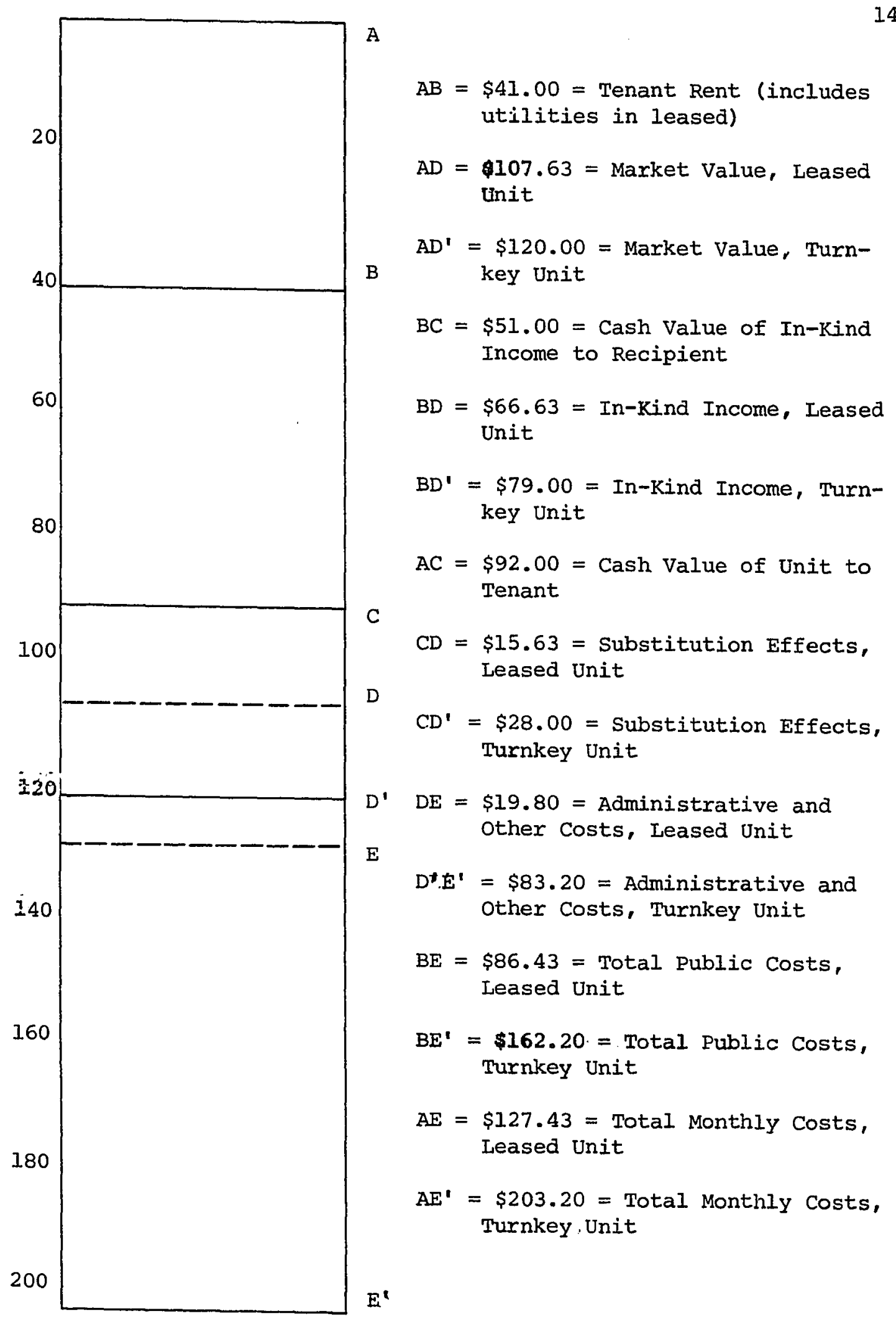

Figure 3. Impact of housing subsidies on two-person, elderly househoid in turnkey or leased unit, annual cash income of $\$ 2,500$. 


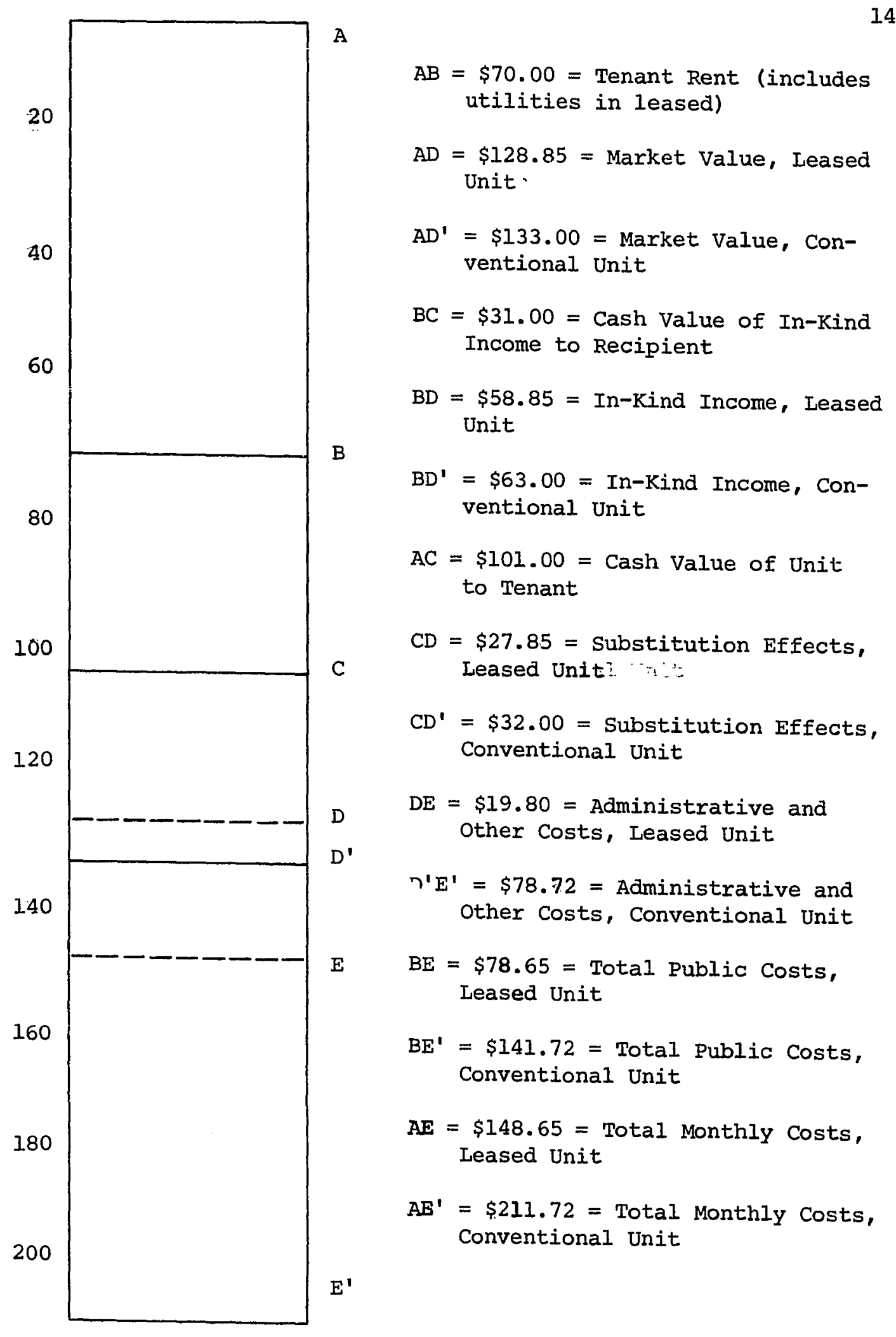

Figure 4. Impact of housing subsidies on four-person household in conventional or leased unit, annual cash income of $\$ 4,500$. 
in Table XXVII; at $\$ 2500$ per year, the couple would pay HAP $\$ 41$ per month for a Turnkey unit and approximately the same to HAP and private utilfty vendors for a leased unit. Therefore, in terms of the model. in Figure 2, $A B$ or tenant rent in Figure 13 is $\$ 41$.

$\mathrm{AD}$ or the market value of a leased unit is $\$ 107.63$ (Table XVII) while $A D^{\prime}$, the market value of a Turnkey unit is $\$ 120.00$ (Table XVI). The market value minus the tenant's rent is the amount of in-kind income provided to the tenant, $\mathrm{BD}$ or $\mathrm{BD}^{\prime} \cdot$ BDis $\$ 66.63$ (\$799.56 annual$1_{y}$ ) for leased housing and $\mathrm{BD}^{\prime}$ is $\$ 70.00$ ( $\$ 948.00$ annually) for Turnkey housing. As indicated in Chapter IV, this market value of the in-kind transfer may not be identical with its cash value to the tenant. To estimate the cash falue of the unite to the tenant, it is necessary to determine what the tenant would be likely to spend on housing, if his income were entirely in cash. Table XVIII, which contains typical housing expenditures by income class and household size, was employed to establish the tenant's point of indifference between a cash and an in-kind housing subsidy, or the cash value of the HAP unit to the tenant. To locate the relevant income class in Table XVIII the couple's in-kind income, $\mathrm{BD}$ or $\mathrm{BD}$ ', must be added to their cash income, so that a comparison may be made with the consumption pattern of a two person household of similar total income whose income is entirely in cash. In Figure 3, when in-kind income is added to cash income, the household moves up to the $\$ 3000-3999$ income class in terms of Table XVIII. Thus $A C$, or the arount the couple would be expected to spend on housing if their income were entirely in cash, is equal to $\$ 92.00$. BC or the cash value of the in-kind income to the recipient, is $\$ 51.00$. 
TABIE XXVII

HOUSING AUTHORITY OF RORTLAND, MONTHLY RENT SCHEDULES, 1972

Elderly 2.Person Househälid

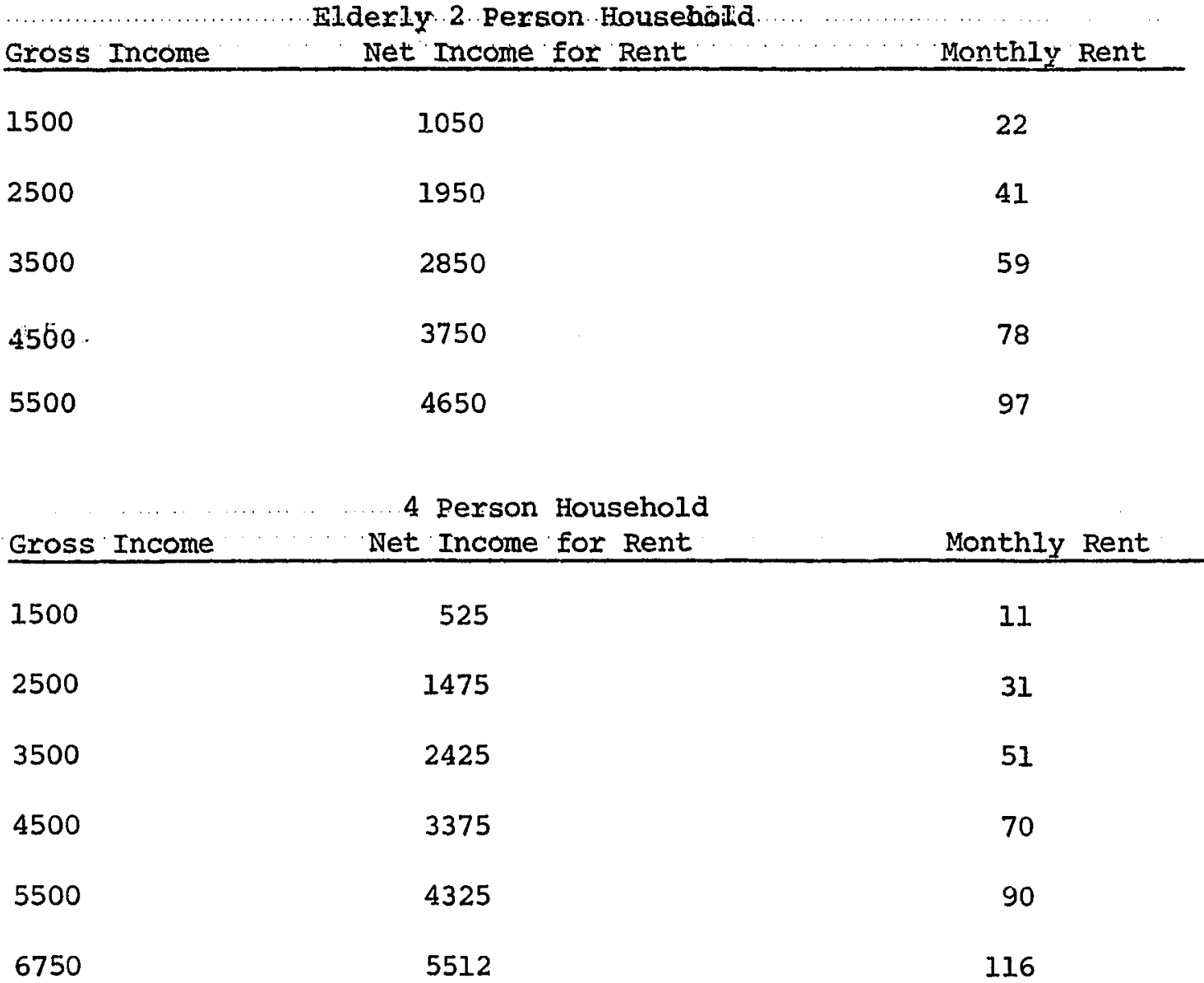

1

Source: Housing Authority of Portland, Records. 
$\mathrm{CD}$ and $\mathrm{CD}$. the market value of the unit minus the cash value of the unit to the tenant, are the substitution effects or the distortion in consumption patterns induced by the in-kind housing subsidies. For leased housing, the couple expands its housing consumption by $\$ 15.63$ or $17 \%$ while in Turnkey housing, consumption is increased by $\$ 28.00$ or $30 \%$. From the point of view of the tenant, subsidized housing is a bargain in that the subsidized rent of $\$ 41.00$ per month is $55 \%$ less than the $\$ 92.00$ the couple would expect to pay for an unsubsidized unit of worse quality.

$A E$, $\$ 127.43$, the total monthly cost of the leased unit, was derived from Tables XII and XVII. Total monthly cost of a leased unit is defined as the sum of landlord rent, operating expenditures and utility payments to private vendors. $A E^{\prime}, \$ 203.20$, or the total cost of a Turnkey unit is from Table XV, (total annual cost divided by 12). $D E$ and $D^{\prime} E^{\prime}$, the administrative and other costs, are the difference between the total cost of the units ( $\mathrm{AE}$ and $\mathrm{AE} \mathrm{E}^{\prime}$ ) and the market value of the units ( $A D$ and $\left.A D^{\prime}\right)$. $B E$, the total public costs of the leased unit, was $\$ 86.43$; while BE' the total public cost of the Turnkey unit totaled $\$ 162.20$. For leased housing, administrative costs were $\$ 19.80$ or 23\% of total public costs, while administrative costs in Turnkey units were $\$ 83.20$ or $51 \%$ of total public costs.

Figure 4 traces the impact of in-kind housing subsidies on a four person household with annual cash income of $\$ 4500$ in a two-bedroom conventional public housing or leased unit. All terms are defined in precisely the same way as in Figure 3. In Figure 4, $A B$ or tenant rent equals $\$ 70.00$ (Table XXVII). AD, the market value of the leased 
unit is $\$ 128.85$ (Table XVII). AD', the market value of the conventional unit, is $\$ 133.00$ (Table XVI). BD, the in-kind income provided by the leased unit is $\$ 58.85$ ( $\$ 706$ annually) while $\mathrm{BD}^{\prime}$, the in-kind income associated with the conventional unit is $\$ 63.00 \quad(\$ 756$ annually). In terms of Table XVIII, the household's total cash and in-kind income makes it comparable to a household in the \$5000-5999 income class. AC or the expected housing expenditure for a household in this income class whose income is entirely in cash is $\$ 101.00 . \mathrm{BC}$, the cash value of the in-kind income to the recipient, is $\$ 31.00$. Thus the leased unit induces substitution effects, $C D$, equal to $\$ 27.85$ or a $28 \%$ increase in the household's housing consumption. Conventional public housing increases housing consumption by $\$ 32.00,\left(C D^{\prime}\right)$, or 328 . Total costs, $A E$, for the leased unit are $\$ 148.65$ (Tables XII and XVII) or which $\$ 19.80$ is allocated to administration, DE. For the conventional unit, total costs, $A E "$, are $\$ 211.72$ (Table XV) while administrative costs, $D^{\prime} E^{\prime}$, are $\$ 78.72$. Total public costs, $B E$, were $\$ 78.65$ for the leased unit and $\$ 141.72\left(\mathrm{BE}^{2}\right)$ for the conventional unit. Administrative expenditures were $50 \%$ of total public costs for the conventional unit and 258 of total public costs for the leased unit. The household in Figure 4 paid 318 less for its subsidized unit than it would expect to pay for unsubsidized housing of inferior quality. Figures 3 and 4 demonstrate that housing subsidies do succeed in increasing the housing consumption of their recipients. HAP tenants consumed 17 to 32 percent more housing than they would have, if given an equizalent cash subsidy. From the tenant's point of view, the advantages offered of living in a higher quality, lower priced unit 
than he would be likely to select if he were unsubsidized, apparently outweigh the disutifity experienced in altering preferred consumption patterns. The lengthy waiting lists for admission into subsidized housing programs testify to their popularity among potential recipients. In recent years, 3000 to 4000 households have typicaily appearea on HAP's waiting list. 15

The changes in consumption patterns induced by housing subsidies, when considered in the goods-specific utility interdependence framework, are assumed to produce external social benefits. However, in the case of units owned by the housing authority, these external benefits are associated with extremely high administrative costs. Leased housing in Portland was found to be considerably more efficient. While the impact of leased housing on housing consumption patterns is somewhat smaller than that of public housing, administrative costs are much lower than those associated with publically owned units. These results are in agreement with the work of other investigators who have noted the very large administrative costs involved in the direct public provision of housing units (Chapter III).

Equation 1 of Chapter IV stated that one measure of the minimum social or external benefits required for an in-kind investment to payoff is

1) $S B^{\min }=A E-A C$

or social benefits must equal or exceed total costs minus private

15 Lund, Mc Cutcheon, Jacobson Inc., op. cit., p. 12. 
benefits (the cash value of the in-kind transfer to the recipient). In Figure $3 \mathrm{SB}^{\mathrm{min}}=\$ 35.43$ per unit per month for leased housing and $\$ 111.20$ per unit per month for Turnkey. In Figure $4, \mathrm{SB}^{\text {min }}$ is $\$ 47.65$ for leased and \$110.72 for conventional public housing. Thus in Turnkey and conventional units, the minimum social benefits required exceed the private benefits of the transfer, $(A C)$. In Turnkey, the minimum social benefits needed are $55 \%$ of the total benefits, while in conventional units they are $52 \%$ of the total. In leased housing, the minimum social benefits demanded are still considerable (28\% of the total in Figure 3 and $32 \%$ of the total in Figure 4) but less than those associated with units owned by the housing authority.

A second measure of social benefits, which attempts to assess probable actual benefits rather than the minimum benefits required for program pay-off appears in Equation 2 of Chapter IV:

2) $\mathrm{SB}=\mathrm{CD} \times \mathrm{PR}$

or social benefits are held to be a function of substitution effects times the participation ratio. As an estimate of the magnitude of substitution effects for all HAP households, the average of $\mathrm{CD}$ and $\mathrm{CD}$ ' in Figures 3 and 4 , or $\$ 26.00$, was employed. Therefore total substitution effects are equal to $\$ 93,236$ per month $(\$ 26$ times 3586 , the number of HAP units). Since HAP programs were found to reach only $5 \%$ of the eligible, $P R=.05$. Thus,

3) $\mathrm{SB}=\$ 93,236 \times .05=\$ 4661.80$

or $\$ 2.60$ per unit per month. This rough calculation of social benefits indicates that thny are far less than the minimum social benefits necessary to justify the subsidies on a benefit-cost basis as calculated above 
according to Equation 1. However, this very low estimate of social benefits is the result of defining such benefits very narrowly. The model does not include social benefits which may be derived from income transfers in general, and does not include benefits from public housing which are unrelated to the transfer of income. Other conceptualizations would yield other results.

\section{Summary}

The data presented in this chapter indicate that housing subsidies do not equitable and efficiently redistribute income. By directing large subsidies at a small number of eligible households, housing programs are successful in inducing changes in the consumption patterns of program participants. However, since $95 \%$ of the target population remains untouched, the negative externatlities presumed to be associated with the housing consumption patterns of the target group, as a whole, are not significantly diminished. In addition, the substitution effects induced, are associated with high administrative costs. While housing subsidies may be desirable on other grounds, they are deficient as an income redistribution strategy. 
CHAPTER VI

AN EMPIRICAI INVESTIEATION OF IN-KIND TRANSFERS; THE CASE OF FOOD STAMPS

In this chapter, the model for evaluating in-kind transfer programs presented in Chaptex IV will be applied to the Food Stamp Program in Multnomah County, Oregon for FY 1973. In 1973, the county averaged 40,573 food stamp recipients per month or approximately 15,500 households. Of these, 27,184 or two-thirds were Public Assistant recipients and the remaining 13,389 or one-third were not associated with the Public Assistance Program. ${ }^{1}$ County food stamp personnel certify eligit. bility and distribute stamps to Non-Public Assistance (NPA) households through five branch offices at four geographic locations. Certification and stamp distribution for Public Assistance (PA) households is the responsibility of the Public Assistance Program.

\section{Program Costs}

Direct program costs are shared by program participants and the federal, state and county governments. A summary of these costs appears in Table XxVIII. Purchase payments by county partjoipants totaled $\$ 5,236,199$ in FY $1973-$ an ayerage of $\$ 129.06$ per recipient or $\$ 336,84$

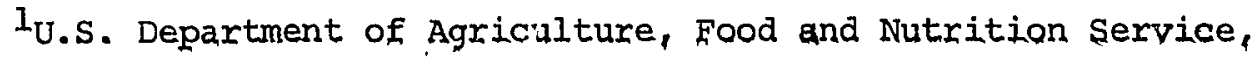
"Food stamp Program: Statistical Summary of Operations," (July, 1972 June, 1974), mimeo. State of Oregon, Public Welfare Division, "Public Welfare in Oregon," (July, 1972 - June, 1973), Table D, mimeo. 
TABLE XXYIII

DIRECT FOOD STAMP PROGRAM COSTS, MULTNOMAH COUNTY, OREGON,FY 1973

\begin{tabular}{lll} 
Total & $\begin{array}{l}\text { Annual per } \\
\text { Recipient }\end{array}$ & $\begin{array}{l}\text { Annual per } \\
\text { Household }\end{array}$ \\
\hline
\end{tabular}

$\underline{\text { Private } \text { Costs }}$

Participant Payments ${ }^{1}$

$\$ 5,236,199$

$\$ 129.06$

$\$ 336.84$

Public Costs

Bonus Payments (USDA) ${ }^{1}$

$7,740,063$

190.77

497.91

Administrative Costs

Federal
USDA $^{2}$
HEW $^{3}$
State $^{4}$
County

TOTAL ADMINISTRATIVE

TOTAL PUBLIC COSTS

TOTAL PUBLIC \& PRIVATE

$$
\begin{array}{r}
1,204,207 \\
94,872 \\
427,725 \\
84,169 \\
\hline
\end{array}
$$

29.68

2.34

1.0 .54

2.07

44.63

$1,811,000$
$8,944,270$
$14,180,469$

77.46

6.11

27.52

5.41

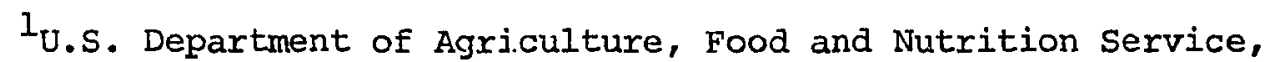
"Food Stamp Program: Statistical Summary of Operations, June, 1973," mimeo.,p. 23.

2 Estimated by multiplying USDA non-bonus program costs per recipient by the number of county recipients. USDA costs are from The Budget of the U.S. Government, Appendix, FY 1975, (Washington, D.C.: U.S. Government Printing Office, 1974), pp. 204-5.

$3_{\text {Estimated, see text. }}$

${ }^{4}$ U.S. Senate, Select Committee on Nutrition and Human Needs, Food Program Technical Amendments, (Washington, D.C.: U.S. Government Printing Office, 1974), pp. 196-7. Partially estimated, see text.

5 Multnomah County Budget, Fiscal Year 1974-1975, (Portland: Multnomah County, 1974), p. 264. 
per household. Participant payments depend upon household size and income net of permissable deductions. Tables XXIX and XXX contain payment schedules, eligibility limits, and the market value of the coupons for 1973 and 1974. The formula for calculating monthly net income for food stamps is extremely complex. Monthly net income is defined as monthly cash gross income minus the following deductions:

1) taxes 2) work expenditures such as union dues and child care 3) $10 \%$ of earned income up to a maximum of $\$ 30$ per month 4), educational expenditures 5) medical expenditures in excess of $\$ 10$ per month and 6) shelter expenditures (rent or mortgage plus utilities including basic telephone service) in excess of $30 \%$ of income net of all other deductions. In addition to this basic formula, special deductions are permitted for unusual emergencies such as funerals or natural disasters. Assets, (bank deposits, stocks, bonds, cash on hand, etc.), may not exceed $\$ 1500$ for a nonelderly household or $\$ 3000$ fo: an elderly household of two or more. Assets do not include a home, household furnishings, or one car. ${ }^{2}$

The bonus value of food stamps distributed in the county in FY 1973 was $\$ 7,740,063$ or $\$ 190.77$ per recipient (Table XXVIII). The bonus value is the difference between the face or market value of food stamp coupons and the payments made by recipients. In other words, the bonus value of the food stamps is the market value of the in-kind income provided by the program to participating households. County

2 U.S. Department of Agriculture, Food and Nutrition Service, Food Stamp Program, (current as of July 1, 1972), pamphlet, pp. 9-10. 
TABLE XXIX

MONTHLY FOOD STAMP COUPON ALIOTMENTS, PURCHASE REQUIREMENTS, AND ELI-: GIBILITY LIMITS, 48 STATES AND DISTRICT OF COLUMBIA, EFFECTIVE JULY 1 , $1972^{1}$

\begin{tabular}{|c|c|c|c|c|c|c|c|c|}
\hline & & & Hor & old si & & & & \\
\hline & 1 & $\therefore 2$ & 3 & 4 & 5 & 6 & 7 & 8 \\
\hline Allotment & $\$ 36$ & $\$ 64$ & $\$ 92$ & $\$ 112$ & $\$ 132$ & $\$ 152$ & $\$ 172$ & $\$ 192$ \\
\hline Net Income & & & Purcl & Requ & ment & & & \\
\hline$\overline{0-} \overline{19.99}$ & 0 & 0 & 0 & 0 & 0 & 0 & 0 & 0 \\
\hline $20-29.99$ & $\$ 1$ & $\$ 1$ & 0 & 0 & 0 & 0 & 0 & 0 \\
\hline $30-39.99$ & 4 & 4 & $\$ 4$ & $\$ 4$ & $\$ 5$ & $\$ 5$ & $\$ 5$ & $\$ 5$ \\
\hline $40-49.99$ & 6 & 7 & 7 & 7 & 8 & 8 & 8 & 8 \\
\hline $50-59.99$ & 8 & 10 & 10 & 10 & 11 & 11 & 12 & 12 \\
\hline $60-69.99$ & 10 & 12 & 13 & 13 & 14 & 14 & 15 & 16 \\
\hline $70-79.99$ & 12 & 15 & 16 & 16 & 17 & 17 & 18 & 19 \\
\hline $80-89.99$ & 14 & 18 & 19 & 19 & 20 & 21 & 21 & 22 \\
\hline $90-99.99$ & 16 & 21 & 21 & 22 & 23 & 24 & 25 & 26 \\
\hline $100-109.99$ & 18 & 23 & 24 & 25 & 26 & 27 & 28 & 29 \\
\hline $110=-119.99$ & 20 & 26 & 27 & 28 & 29 & 31 & 32 & 33 \\
\hline $120-129.99$ & 22 & 29 & 30 & 31 & 33 & 34 & 35 & 36 \\
\hline $130-139.99$ & 24 & 31 & 33 & 34 & 36 & 37 & 38 & 39 \\
\hline $140-149.99$ & 26 & 34 & 36 & 37 & 39 & 40 & 41 & 42 \\
\hline $150-169.99$ & 26 & 36 & 40 & $4 I$ & 42 & 43 & 44 & 45 \\
\hline $170-189.99$ & 26 & 42 & 46 & $\$ 7$ & 48 & 49 & 50 & 51 \\
\hline $190-209.99$ & & 44 & 52 & 53 & 54 & 55 & 56 & 57 \\
\hline $210-229.99$ & & 44 & 58 & 59 & 60 & 61 & 62 & 63 \\
\hline $230-249.99$ & & 44 & 64 & 65 & 66 & 67 & 68 & 69 \\
\hline $250-269.99$ & & & 70 & 71 & 72 & 73 & 74 & 75 \\
\hline $270-289.99$ & & & 74 & 77 & 78 & 79 & 80 & 81 \\
\hline $290-309.99$ & & & 74 & 82 & 84 & 85 & 86 & 87 \\
\hline $310-329.99$ & & & & 86 & 90 & 91 & 92 & 93 \\
\hline $330-359.99$ & & & & 86 & 94 & 97 & 98 & 99 \\
\hline $360-389.99$ & & & & 88 & 98 & 104 & 107 & 108 \\
\hline $390-419.99$ & & & & & 102 & 108 & 116 & 117 \\
\hline $420-449.99$ & & & & & 104 & 112 & 122 & 126 \\
\hline $450-479.99$ & & & & & & 116 & 126 & 130 \\
\hline $480-509.99$ & & & & & & 120 & 130 & 134 \\
\hline $510-539.99$ & & & & & & & 134 & 138 \\
\hline $540-569.99$ & & & & & & & 136 & 142 \\
\hline $570-599.99$ & & & & & & & 136 & 146 \\
\hline $600-629.99$ & & & & & & & & 150 \\
\hline $630-659.99$ & & & & & & & & +15 \\
\hline Max. Net Inc. & 78 & 233 & 307 & 373 & 440 & 507 & 573 & 640 \\
\hline
\end{tabular}




\section{TABLE XXIX}

(continued)

$I_{\text {Source: }}$ U.S. Department of Agriculture, Food and Nutrition Service, "Food Stamp Program, Current as of July 1, 1972," mimeo., pp. 26-27. 
TABLE XXX

MONTHLY FOOD STAMP COUPON ALLOTMENTS, RURCHASE REQUIREMENTS, AND ELI-. GIBILITY LIMITS, 48 STATES AND DISTRICT OF COLUMBIA, EFFECTIVE JULY 1 , 1974

\begin{tabular}{|c|c|c|c|c|c|c|c|c|}
\hline & & & Hou & ehold & ize & & & \\
\hline & 1 & 2 & 3 & 4 & 5 & 6 & 7 & 8 \\
\hline Allotment. & $\$ 46$ & $\$ 82$ & $\$ 118$ & $\$ 150$ & $\$ 178$ & $\$ 204$ & $\$ 230$ & $\$ \$ 256$ \\
\hline Net Income & & & $\mathrm{Pu}$ & chase & equir & nent & & \\
\hline$\overline{0-} \overline{19.99}$ & 0 & 0 & $\overrightarrow{0}$ & 0 & 0 & 0 & 0 & 0 \\
\hline $20-29.99$ & $\$ 1$ & $\$ 1$ & 0 & 0 & 0 & 0 & 0 & $\theta$ \\
\hline $30-39.99$ & 4 & 4 & $\$ 4$ & $\$ 4$ & $\$ 5$ & $\$ 5$ & $\$ 5$ & $\$ 5$ \\
\hline $40-49.99$ & 6 & 7 & 7 & 7 & 8 & 8 & 8 & 8 \\
\hline $50-59.99$ & 8 & 10 & 10 & 10 & 11 & 11 & 12 & 12 \\
\hline $60-69.99$ & 10 & 12 & 13 & 13 & 14 & 14 & 15 & 16 \\
\hline $70-79.99$ & 12 & 15 & 16 & 16 & 17 & 17 & 18 & 19 \\
\hline $80-89.99$ & 14 & 18 & 19 & 19 & 20 & 21 & 21 & 22 \\
\hline $90-99.99$ & 16 & 21 & 21 & 22 & 23 & 24 & 25 & 26 \\
\hline $100-109.99$ & 18 & 23 & 24 & 25 & 26 & 27 & 28 & 29 \\
\hline $110-119.99$ & 21 & 26 & 27 & 28 & 29 & 31 & 32 & 33 \\
\hline $120-129.99$ & 24 & 29 & 30 & 31 & 33 & 34 & 35 & 36 \\
\hline $130-139.99$ & 27 & 32 & 33 & 34 & 36 & 37 & 38 & 39 \\
\hline $140-149.99$ & 30 & 35 & 36 & 37 & 39 & 40 & 41 & 42 \\
\hline $150-169.99$ & 33 & 38 & 40 & $4 I$ & 42 & 43 & 44 & 45 \\
\hline $170-180.99$ & 36 & 44 & 46 & 47 & 48 & 49 & 50 & 51 \\
\hline $190-209.99$ & 36 & 50 & 52 & 53 & 54 & 55 & 56 & 57 \\
\hline $210-229.99$ & & 56 & 58 & 59 & 60 & 61 & 62 & 63 \\
\hline $230-249.99$ & & 62 & 64 & 65 & 66 & 67 & 68 & 69 \\
\hline $250-269.99$ & & 62 & 70 & 71 & 72 & 73 & 74 & 75 \\
\hline $270-289.99$ & & 62 & 76 & 77 & 78 & 79 & 80 & 81 \\
\hline $290-309.99$ & & & 82 & 83 & 84 & 85 & 86 & 87 \\
\hline $310-329.99$ & & & 88 & 89 & 90 & 91 & 92 & 93 \\
\hline $330-359.99$ & & & 94 & 95 & 96 & 97 & 98 & 99 \\
\hline $360-389.99$ & & & 100 & 104 & 105 & 106 & 107 & 108 \\
\hline $390-419.99$ & & & 100 & 113 & 114 & 115 & 116 & 117 \\
\hline $420-449.99$ & & & & 122 & 123 & 124 & 125 & 126 \\
\hline $450-479.99$ & & & & 126 & 132 & 133 & 134 & 135 \\
\hline $480-509.99$ & & & & 126 & 141 & 142 & 143 & 144 \\
\hline $510--539.99$ & & & & & 150 & 151 & 152 & 153 \\
\hline $540-569.99$ & & & & & 150 & 160 & 161 & 162 \\
\hline $570-599.99$ & & & & & 150 & 169 & 170 & 171 \\
\hline $600-629.99$ & & & & & & 172 & 179 & 180 \\
\hline $630-659.99$ & & & & & & 172 & 188 & 189 \\
\hline $660-689.99$ & & & & & & 172 & 1.94 & 198 \\
\hline $690-719.99$ & & & & & & & 194 & 207 \\
\hline $720-749.99$ & & & & & & & 194 & 216 \\
\hline
\end{tabular}


TABLE XXX

(continued)

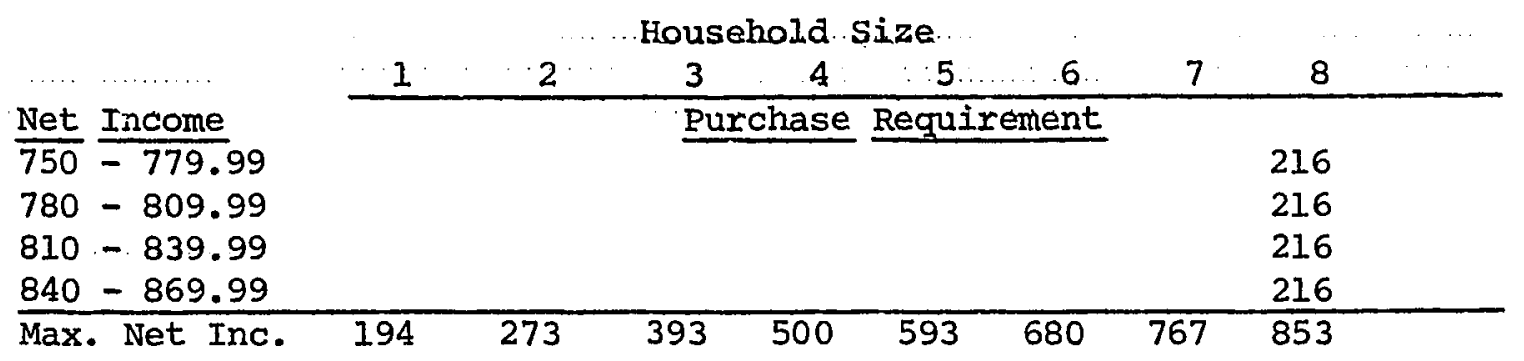

${ }^{1}$ Source; U.S. Congress, Joint Economic Committee, Subcommittee on Fiscal Policy, Studies in Public Welfare, Paper No. 17, National Survey of Food Stamp and Food Distribution Program Recipients, A Summary of Findings of Income Sources and Amounts and Incidence of Multiple Benefits=, (Washington, D.C.: U.S. Government Printing Office, 1974), pp. 18, 21. 
honuses per recipient were slightly higher than the average annual bonus of $\$ 174.33$ that prevailed nationally (Table XXXI). Food stamp bonus payments are funded completely by the U.S. Department of Agriculture (USDA).

The administrative costs of the program are shared by three levels of government (see Chapter III). In FY 1973, the USDA's food stamp budget explicitly allocated only $\$ 23.8$ million or $\$ 1.95$ per recipient to administration. ${ }^{3}$ However, Table XXXI reveals that program costs beyond the value of the bonuses were substantially higher. Of the $\$ 204$ per recipient spent by the USDA, $\$ 29.68$ or $15 \%$ failed to reach the participants in the form of stamps. Administrative costs for Public Assistance households are not "broken out" of the HEW Public Assistance budget. The costs allocated to HEW in Table XXVI.II were estimated by employing known county and state expenditures and the prevailing cost-sharing formula. It is estimated that HEW spent approximately $\$ 94,872$ in the county for food stamp administration in FY 1973.

The county budget shows that Multnomah County spent $\$ 84,169$ on distributing food stamps in 1973 (Table XXVIII). In the same period, the state of Oregon reported total expenditures of $\$ 876,000$ on the program, excluding costs shared with HEW for PA households. ${ }^{4}$ Since Multnomah County contained $38 \%$ of the state's recipients, $\$ 330,880$ of state

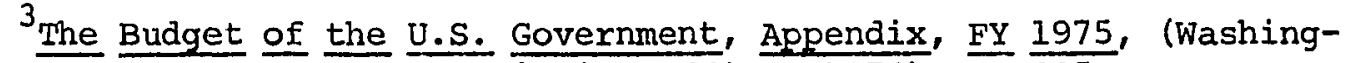

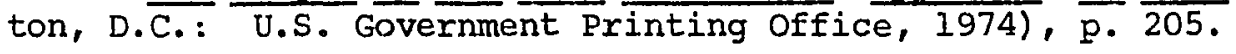

4 U.S. Senate, Select Committee on Nutrition and Human Needs, Food Program Technical Amendments, (Whashington, D.C.: U.S. Government Printing Office, 1974), p. 196. 
U.S. DEPARTMENT OF AGRICULTURE, FOOD STAMP PROGRAM COSTS, U.S:, FY : 1973

\begin{tabular}{crc} 
& \multicolumn{1}{c}{ Total } & $\begin{array}{c}\text { Annual per } \\
\text { Recipient }\end{array}$ \\
\cline { 2 - 3 } Value of Bonus Stamps Issued 1 & $\$ 2,132,600,000$ & $\$ 174.33$ \\
Non-Bonus Expenditures & $363,600,000$ & 29.68 \\
\cline { 2 - 3 } TOTAL USDA COSTS & $\$ 2,495,654,000$ & $\$ 204.01$ \\
\hline
\end{tabular}

Average Monthly Number of

Recipients $=12,233,382^{2}$

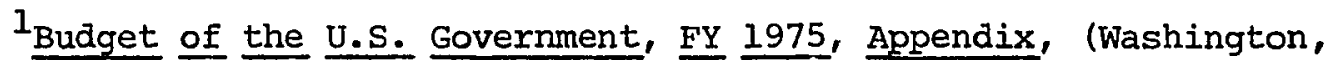
D.C.: U.S. Government Printing Office, 1974), pp. 204-205.

2U.S. Department of Agriculture, Food and Nutrition Service, "Food Stamp Program, Statistical Summary of Operations," (July, 1972 June, 1973), mimeo. 
expenditures were allocated to county administration. ${ }^{5}$ of this county share, $\$ 280,563$ is assumed to cover stamp distribution in conformance with the 30/70 county/state cost-sharing formula. The remaining $\$ 52,317$ is assumed to be the state share of certifying NPA households, which according to the USDA formula is $37.5 \%$ of the certification costs of those households. Dividing the total NPA certification budget by the number of NPA recipients resulted in a NPA certification cost of $\$ 10.42$ per recipient.or $\$ 27.20$ per household. Willard Renkin, Multnomah Caunty Food Stamp Coordinator, suggested that certification costs for PA recipients were roughly two-thirds of those for NPA recipients. 6 In a Congressional survey of food stamp administrative costs, the state of North Dakota suggested the same ratio. ${ }^{7}$ This ratio was used to estimate state and HEW costs for PA households in Table XXVIII. Table XXVIII contains only the direct costs of the Food stamp Program. However, the program has indirect costs as well, many of which are difficult to quantify. An informal telephone survey of the major supermarket chains in the county revealed that food stamp purchases averaged about 2 minutes more per transaction in check-out time than did regular purchases. The extra time is primarily due to the

5 U.S. Department of Agriculture, Food and Nutrition Service, "Food Stamp Program: Statistical Summary of Operations," op. cit.

${ }^{6}$ Willard Renkin, Food Stamp Coordinator, Multnomah County, Oregon, interview, November 27, 1974.

7U.S. Senate, op. cit., p. 184. 
necessity of separating items which may be purchased with food stamps from those which may not (non-food products, alcohol, cigarettes, etc.) and tallying the two categories separately. Supermarket mana-: gers indicated that frequently shoppers do not warn the checkers, in advance, of a food stamp transaction. When this occurs, the checkers tally all of the items together as they would for a normal purchase. When the shopper attempts to pay in food stamp script, the order must be unpacked, sorted, and retallied to conform to program rules. Additional checker time is also involved in making change in script, rather than cash, as the program requires. The magnars also reported additional clerical work in connection with bundling and canceling the food stamp coupons. Despite the extra burden the program imposes on the supermarkets, the managers, with one exception, welcomed the program as beneficial to their businesses. ${ }^{8}$ A rough calculation of supermarket food stamp costs, based on the two minutes extra per transaction reported above and the prevailing checker wages in 1973, was made. It is estimated that indirect supermarket costs in the county were about $\$ 6.40$ per recipient per year ( $\$ 16.59$ per household) ox over $\$ 250,000$ total. These indirect costs are undoubtedly passed along to the general public.

Food stamp coupons move from the markets to the commercial banks to the Federal Reserve Banks where they are eyentually destroyed. Telephone interyiews with bank officials indicated that extra clerical personnel have been hired to handle food stamps. The

${ }^{8}$ Interviews with the managers of Kienows, Albertsons, Fred Meyer, and Safeway, November, 1974. 
Portland area Federal Reserve Bank which serves Oregon, Southern Washington, Northern Idaho and Nevada, was processing 3 million food stamp coupons per month in the Fall of 1974. This volume required the services of three full-time clerks and a part-time supervisor. Additional security personnel have also been needed because food stamps are treated like cash, rather than checks. ${ }^{9}$ A very rough and conservative estimate of the county share of food stamp banking costs in 1973 is $\$ 15,000$, less than $\$ 1.00$ per household per year.

Other indirect program costs which have not been measured are the travel costs and waiting time demanded of program participants. Inraddition, no attempt has been made to calculate the psychic costs which may be associated with being identified as a food stamp reci-. pient. For the purpose of evaluating the Food stamp Program in terms of the model presented in Chapter IV, only the direct costs shown in Table XXVIII will be considered. This conservative approach will enhance the comparability of the food stamp results with analyses of other transfer programs which rarely include indirect costs, despite their relevance.

\section{Market Value}

The market value of food stamp coupons is simply their face value which is equal to the sum of participant payments and the bonus provided by the USDA. In 1973, the arerage annual value of food

9 Kenneth Carr, Fiscal Department, Federal Reserve Bank, Portland area, interview, November 8, 1974. 
stamp coupons per recipient in Multnomah County was $\$ 319.83$ or $\$ 843.75$ per household. Of this $\$ 129.06$ per recipient $(\$ 336.84$ per hosuehold) or $40 \%$ was provided by the participant. The remaining $\$ 190.77$ per recipient ( $\$ 497.91$, per household) or 608 was furnished by the USDA (Table XXVIII). Nationally, in the same period, the average coupon value per recipient was $\$ 317.98$ of which $45 z$ represented recipient payments and $55 \%$ was funded by the USDA. 10

\section{Private Benefits: Cash Value of Food Stamps to Recipients}

In an effort to estimate what households of various sizes and income would be likely to spend on food, if their income were entirely in cash, the Bureau of Labor Statistics' Consumer Expenditure Survey of 1960-61, described in the preceding chapter, was employed. No satisfactory data sources of more recent vintage were located. The 1960-61 results were updated through the use of the food expenditure component of the Consumer Price Index. ${ }^{11}$ Table XXXII contains estimated food expenditures by household size and income class for FY 1973. Incomplete and partial results of the 1972-73 survey, released by BIS in April of 1975 , suggest that the values in Table XXXII may be up to $20 \%$ too high. 12 As with the housing expenditures in Table XVIII,

10 The Budget of the U.S. Government, op. cit.

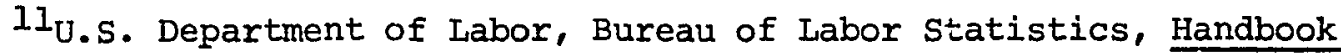
of Labor Statistics, 1973, (Washington, D.C.: U.S. Government Printing Office, 1974), p. 299.

12 Julius Shiskin, "The 1972-73 Consumer Expenditure Survey, Some First Year Diary Results," U.S. Department of Labor, (April 16, 1975), mimeo. 
TABLE XXXII

ESTIMATED MONTHLY FOOD EXPENDITURES BY HOUSEHOLD SIZE AND INCOME CLASS, URBAN U. S., FISCAL YEAR 1973 ${ }^{1}$

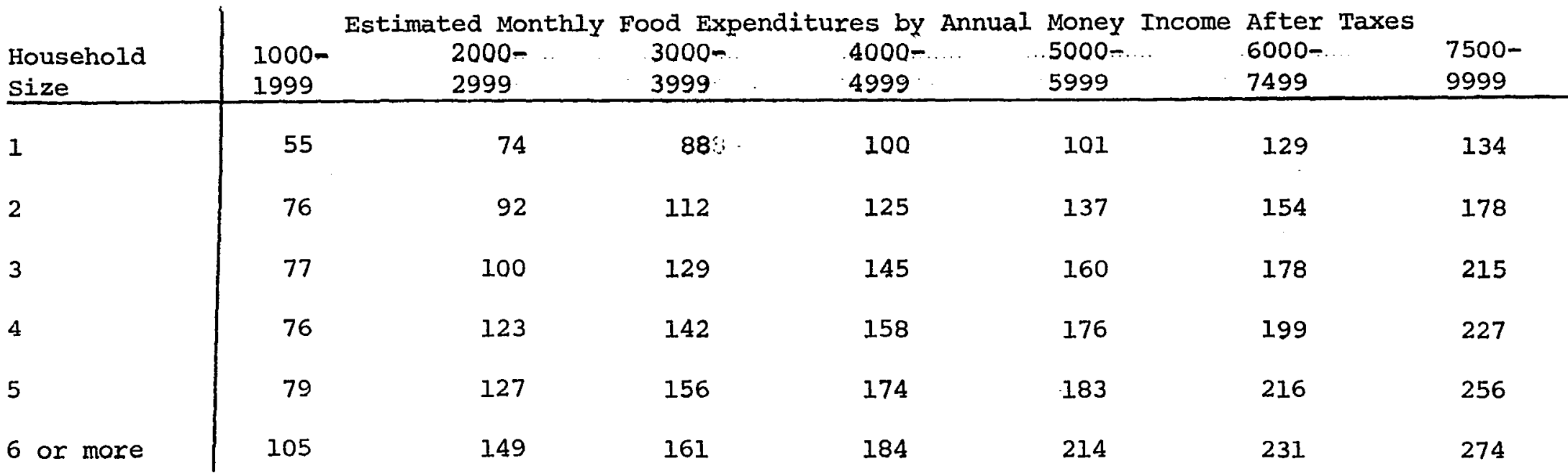

${ }^{I}$ Source: U.S. Department of Labor, Bureau of Labor Statistics, Consumer Expenditures and Income: Cross Classification of Family Characteristics, Urban U.S., 1960-61, supplement 2 , Part A to BLS Report 237-38, (Washington, D.C.: U.S. Government Printing Office, 1965), Tables 1la-g. Food expenditures for FY 1973 were estimated by applyirg the total food component of the Consumer price Index to the food expenditures reported in the survey. The Consumer Price Index appears in U.S. Department of Labor, Bureau of Labor Statistics, Handbook of Labor Statistics, 1973, (Washington, D.C.: U.S. Government Printing Office, 1974), pp. 299-304. 
it would be desirable to reyise Table XXXII, as necessary, when the results from the new suryey become ayailäble.

\section{DisEribution of Private Benefits: Recipient Characteristics}

Information on the characteristics of food stamp recipients is surprisingly scarce. The onty major national survey of participating households was conducted in 1974 by Chilton Research Services for the Subcommittee on Fiscal Policy. This survey relied on personal interviews with recipients and was plagued with non-response. Of a total of 3,600 sample households, only 2,191 or $61 \%$ were ultimately interviewed. In addition, the survey elicited information pertaining to November of 1973 in February and March of 1974. The high rate of nonresponse, the time lag associated with the interviews and the dependence on recipient self-report for data relating to income and expenditures produces an undetermined but potentially significant bias in the results. 13

Some of the principle findings of the Chilton survey were that the mean cash, after tax, income of lood stamp households was $\$ 238$ per month while in-kind income averaged $\$ 126$ per month. Public cash and in-kind income accounted for about $80 \%$ of total income whide income from private sources amounted to only $20 \%$ of the total. Benefits from Public Assistance programs were receiyed by $60 \%$ of the suryeyed house-

13U.S... Congress; . Joint Economic Committee, Subcomittee on Fiscal Policy, Stadies in Public Welfare, Paper No. 17, National Survey of Food stamp and Food Distribution Program Recipients: A sumary of Findings of Income Sources and Amounts and Incidence of Multiple Benefits, (Washington, D.C.: : U.S. Government Printing Office, 1974). 
holds. The average recipient household obtained benefits from three major federal programs. Household size averaged 3.2 persons, while one and two person households made up one-half of those surveyed. Female headed households were $66 \%$ of the total, while Blacks constituted $37 \%$ of those interviewed. 14 The average deduction from gross income, under the program formula for determining net income for Food Stamps, was approximateiy \$73-78 per month. On the average, net income for food stamps was 70 to 72 percent of gross pre-tax income for interviewed households. 15

In an effort to investigate the characteristics of recipient households in greater detail and to avoid the possible biases associated with the Chilton survey, a study of 498 Non-Public Assistance food stamp households in Multnomah County, Oregon was conducted in December of 1974. A 6 percent random sample of active NPA files was pulled and data were gathered from agency records. The use of records rather than interviews, has the advantage of at least minimal verification of income, rent, and other expenditure data by food stamp personnel. In addition, the records indicate which deductions were actually permitted from gross income in the computation of program benefits. In some cases, the deductions itemized by applicants differed from those-allowed by the agency. This divergence raises some

14 Ibia., pp. 1-2.

. ${ }^{15}$ Gary W. Bickel and Maurice Mac Donald, "Participation Rates in the Food Stamp Program: Estimated Levels for 1974, by State,"..... in U.S. Senate, Select Committee on Nutrition and Human Needs, Report on Nutrition and Special Groups, Appendix B to Part I - Food stamps, (Washington, D.C.: U.S. Government Printing Office, 1975). 


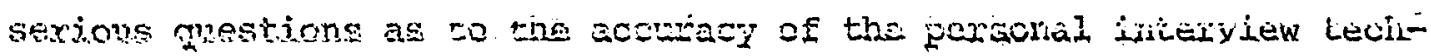
nique for the evaluation of program benefits. Another advantage of working with agency records was the elimination of the probiem of non-response; all active files were accessible. Unfortunately, it was not possible to survey Public Assistance food stamp households, so the results are not representative of the food stamp population as a whole. However, in considering issues of program expansion and in calculating the number of potential eligible, the characteristics of the NPA caseload are most pertinent. While in the county, by late 1974, about $55 \%$ of recipient households were associated with the Public Assistance program 16 , nationally, NPA households now dominate the program (see Chapter III). It is the NPA share of the total that has been growing most rapidly and that will continue to grow. Currently, in the county, about $85 \%$ of Public Assistance households are receiving stamps. This is near the upper limit of PA participation anticipated by program officials. ${ }^{17}$ since virtually all PA households that wish to participate are doing so, those eligible, but not participating, are primarily NPA households. Tables XXXIII through XL contain the results of the Multnomah County NRA survey. Table XXXIII indicates that participating households are small; mean size was 2.53 persons while median size was 2 . Male heads of householan: $\quad 355 \%$ of the NPA sample. Benefits were

16Douglas Yeater, Supervisor, Issuing Section, Food Stamp Program, Multnomah County, Oregon, interview, Februaryu 7, 1975.

17 Ibid. 
CHARACTERISTICS OF NON-PUBLIC ASSISTANCE FOOD STAMP RECIPIENTS: HOUSEHOLD SIZE, SEX, AND AGE OF HEAD, MULTNOMAH COUNTY, OREGON, DEC., $1974^{1}$

Household Size

1

2

3

4

5

6 or more

TOTAL

Mean Household Size $=2.53$

Median Household Size $\neq 2.00$

Sex of $\underline{\text { Head }}$

Male

Female

TOTAL

Age of

Under 18

$18-24$

$25-34$

$35-44$

$45-54$

$55-64$

$65+$

TOTAL

\begin{tabular}{rr} 
Number & Percent \\
\cline { 2 - 2 } 208 & 41.8 \\
92 & 18.5 \\
72 & 14.5 \\
51 & 10.2 \\
40 & 8.0 \\
35 & 7.0 \\
\hline 498 & 100.0
\end{tabular}

274

224

55.0

45.0

498

100.0

\begin{tabular}{|c|c|c|}
\hline & 3 & 0.6 \\
\hline & 141 & 28.3 \\
\hline & 149 & 29.9 \\
\hline & 62 & 12.4 \\
\hline & 45 & 9.0 \\
\hline & 22 & 4.4 \\
\hline & 76 & 15.3 \\
\hline TOTAL & 498 & $100.0^{*}$ \\
\hline
\end{tabular}

Mean Age of Head $=38.1$

Median Age of Head $=30.0$

*Does not equal 100.0 due to rounding error.

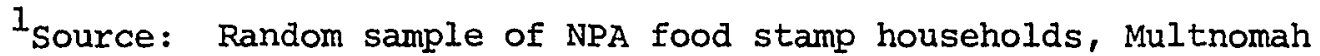
County, Oregon, December, 1974. See text for description. 
heavily concentrated on young households: $58.8 \%$ of household heads were below age 35 . Only $25.8 \%$ of the sample had heads between ages 35 and 64. Elderly households comprised $15.3 \%$ of the total. Table XXXIV indicates that the reported value of the assets of surveyed households was very low.

Table XxxV contains mean gross monthly income, mean net monthly income (income after deductions permitted by the program formula), and mean bonus values by household size for the sample as a whole. For the total sample, gross income averaged $\$ 256$ per month, mean monthly net income was $\$ 132$ and the average monthly bonus was $\$ 66$. The difference between net and gross income was $\$ 124$ per month. Thus net income for the sample was only $52 \%$ of gross income. Tables XXXVI, XXXVII and XXXVIII contain gross income, net income, and bonus data by household size and income class. These tables indicate that the Food stamp income determination formula tends to result in proportionately larger deductions from gross income for upper income recipients. Figure 5 plots data from Tables XXXVI and XXXVII for all classes in which there are a minimum of five observations. Figure 5 reveals that the relationship between gross and net income is not linear. As gross income increases, proportionilincreases in net income diminish at the upper end of the income spectrum of survey households. Figure 6 which plots data from Tables XXXVI and XXXVIII indicates that the relationship between food stamp bonuses and gross income is also non-linear as bonus values are an inverse function of net income. As gross income 
TABIE XXXIV

CHARACTERISTICS OF NON-PUELIC ASSISTANCE FOOD STAMP RECÆPIENTS: ASSETS, MULTNOMAH COUNTY, OREGON, DECEMBER, 1974

Cash on Fand

0

$\$ 1-49$

$\$ 50-99$

$\$ 100-149$

$\$ 150$ or more

TOTAI

Value of Other Assets

(stocks, bonds, bank accounts, etc.)

0

$\$ 1-49$

$\$ 50-99$

$\$ 100-199$

$\$ 200-299$

$\$ 300-399$

$\$ 400-499$

$\$ 500-999$

$\$ 1000-\$ 1499$

TOTAL

Car Ownership

No Car

One Car

Two or more

TOTAL
Number of
Households Percent

194

257

23

13

11

39.0

51.6

4.6

2.6

2.2

498

100.0

259

113

24

35

12

8

11

24

12

498

52.0

22.7

4.8

7.0

2.4

1.6

2.2

4.8

2.4

100.0

\begin{tabular}{rr}
237 & 47.6 \\
235 & 47.2 \\
26 & 5.2 \\
\hline 498 & 100.0
\end{tabular}

${ }^{1}$ Source: Random sample of NPA food stamp households, Multnomah County, Oregon, December, 1974. See text for description. 
CHARACTERISTICS OF NON-PUBLIC ASSISTANCE FOOD STAMP RECIPIENTS: GROSS MONTHLY INCOME, NET MONTHLY INCOME, AND BONUS VALUE, BY HOUSEHOLD SIZE, MULTNOMAH COUNTY, OREGON, DECEMBER, 1974 1

\begin{tabular}{|c|c|c|c|c|c|c|}
\hline Household & Gross & Monthly Income & Net $M$ & thly Income & Bonu & \\
\hline Size & Mean & Stand. Dev. & Mean & Stand. Dev. & Mean & Stand.Dev. \\
\hline $1 \quad(\mathrm{~N}=208)$ & 145 & 90 & 70 & 61 & 33 & 13 \\
\hline $2(N=92)$ & 230 & 153 & 103 & 83 & 58 & 21 \\
\hline $3(N=72)$ & 331 & 186 & 156 & 124 & 79 & 33 \\
\hline $4 \quad(\mathrm{~N}=51)$ & 387 & 180 & 210 & 132 & 100 & 54 \\
\hline $5 \quad(N=40)$ & 390 & 242 & 216 & 174 & 117 & 51 \\
\hline $6+(N=35)$ & 481 & 235 & 318 & 187 & 140 & 62 \\
\hline TOTAL SAMP & & & & & & \\
\hline$(\mathrm{N}=498)$ & 256 & 193 & 132 & 130 & 66 & 48 \\
\hline Median Gro & ss Mont & IIy Income $=\$ 2$ & & & & \\
\hline Median Net & Monthl & Income $=\$ 121$ & & & & \\
\hline
\end{tabular}


TABLE XXXVI

CHARACTERISTICS OF NON-PUBLIC ASSISTANCE FOOD STAMP RECIPIENTS: GROSS MONTHLY INCOME BY HOUSEHOID SIZE AND INCOME CLASS, MULTNOMAH COUNTY, OREGON, DECEMBER, $1974^{1}$

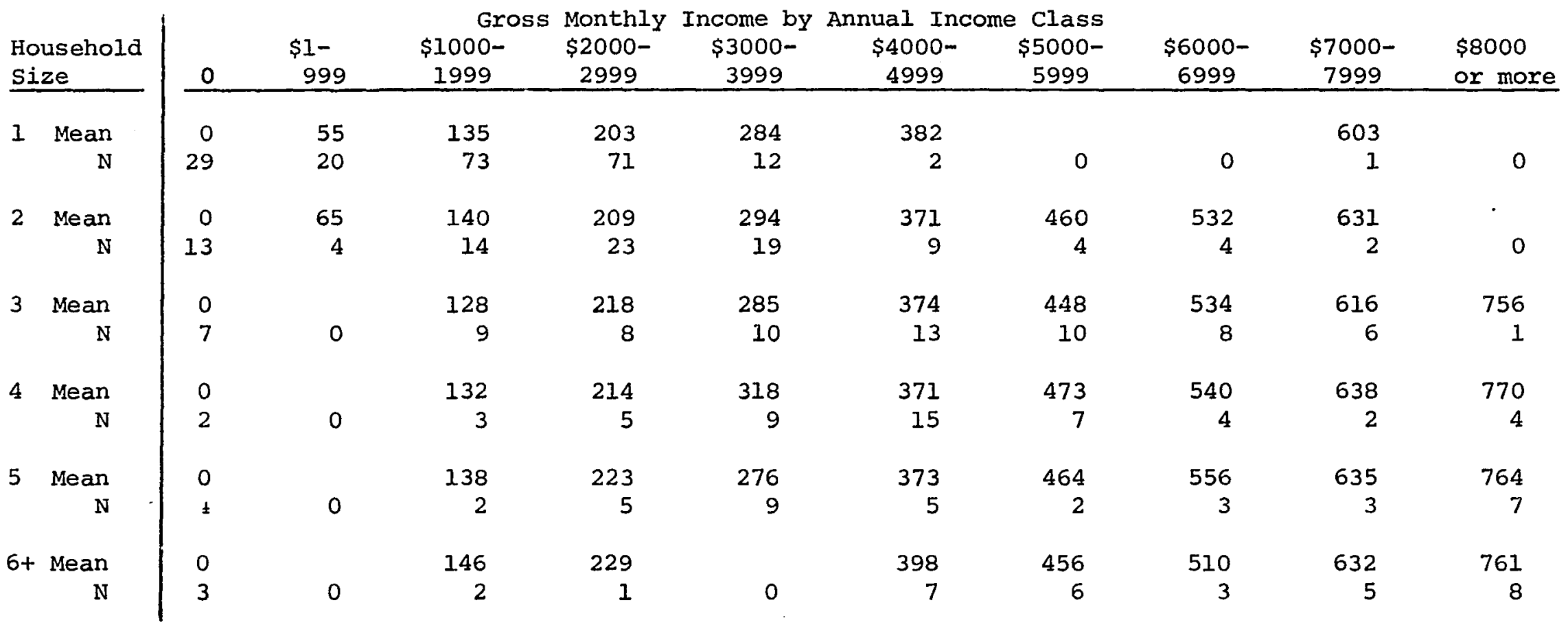

lsource: Random sample of NPA food stamp households, Multnomah County, Oregon, December, 1974. see text for description. 
TABIE XXXVII

CHARACTERISTICS OF NON-PUBLIC ASSISTANCE FOOD STAMP RECIPIENTS: NET MONTHLY INCOME FOR FOOD STAMPS BY HOUSEHOLD SIZE AND GROSS INCOME CLASS, MULTNOMAH COUNTY, OREGON, DECEMBER, $1974^{1}$

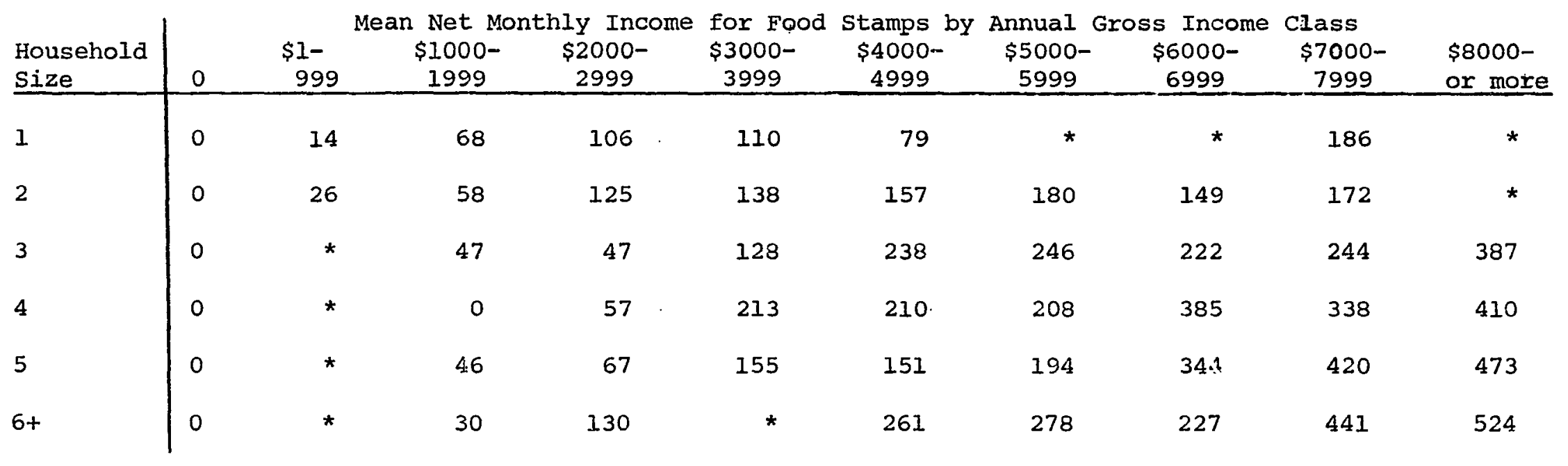

${ }^{*}$ No observations in this class.

Isource: Ranäom sample of NPA food stamp households; Multnomah County, Oxegon, December, 1974. See text for description. 
TABLE XXXVIII

CHARACTERISTICS OF NON-PUBLIC ASSISTANCE FOOD STAMP RECIPIENTS: MONTHLY FOOD STAMP BONUS BY HOUSEHOLD SIZE AND INCOME CLASS, MUITNOMAH COUNTY, OREGON, DECEMBER, $1974^{1}$

\begin{tabular}{|c|c|c|c|c|c|c|c|c|c|c|}
\hline $\begin{array}{l}\text { Household } \\
\text { Size }\end{array}$ & 0 & $\begin{array}{l}\$ 1- \\
\because 999 \\
\end{array}$ & $\begin{array}{r}\text { Mean } \\
\$ 1000- \\
1999 \\
\end{array}$ & $\begin{array}{c}\text { Monthly } \\
\$ 2000- \\
2999 \\
\end{array}$ & $\begin{array}{c}\text { Food stamp } \\
\$ 3000- \\
3999 \\
\end{array}$ & $\begin{array}{c}\text { Bonus by } \\
\$ 4000- \\
4999 \\
\end{array}$ & $\begin{array}{c}\text { Annual Gross } \\
\$ 5000- \\
5999 \\
\end{array}$ & $\begin{array}{c}\text { Income } \\
\$ 6000- \\
6999 \\
\end{array}$ & $\begin{array}{c}\text { Class } \\
\$ 7000- \\
7999 \\
\end{array}$ & $\begin{array}{l}\$ 8000- \\
\text { or more }\end{array}$ \\
\hline 1 & 46 & 45 & 34 & 26 & 26 & 33 & * & * & 10 & * \\
\hline 2 & 82 & 79 & 71 & 53 & 51 & 43 & 38 & 45 & 38 & * \\
\hline 3 & 118 & * & 109 & 108 & 86 & 59 & 58 & 59 & 53 & 18 \\
\hline 4 & 150 & $\star$ & 150 & 138 & 95 & 93 & 94 & 41 & 54 & 34 \\
\hline 5 & 178 & $\star$ & 166 & 161 & 136 & 136 & 79 & 102 & 43 & 45 \\
\hline $6+$ & 246 & $\star$ & 197 & 155 & x & 148 & 155 & 184 & 112 & 66 \\
\hline
\end{tabular}

*No observations in this class.

Isource: Random sample of NPA food stamp households, Multnomah County, Oregon, December, 1974. see text for description. 

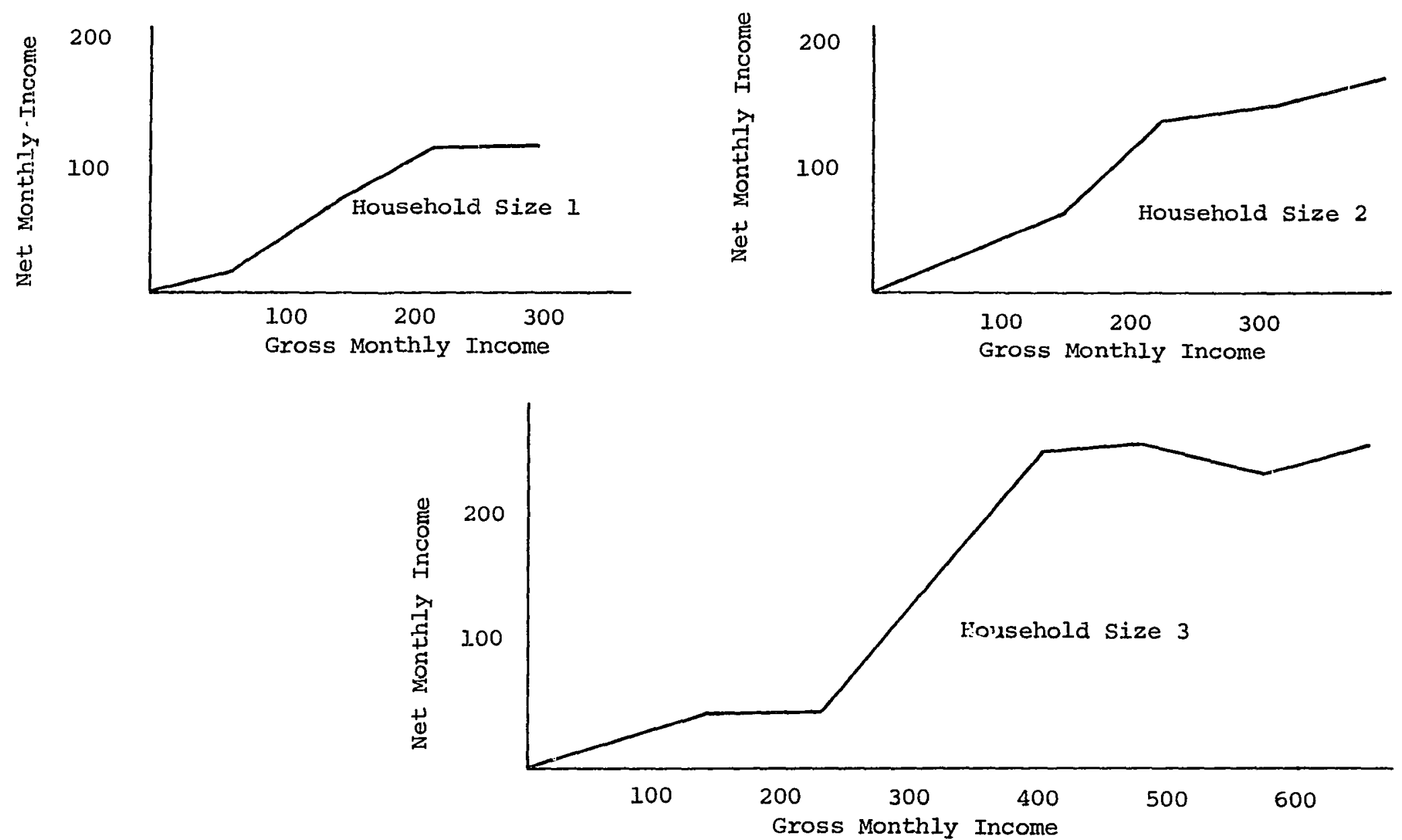

Figure 5. Characteristics of non-public assistance food stamp recipients: net and gross income 


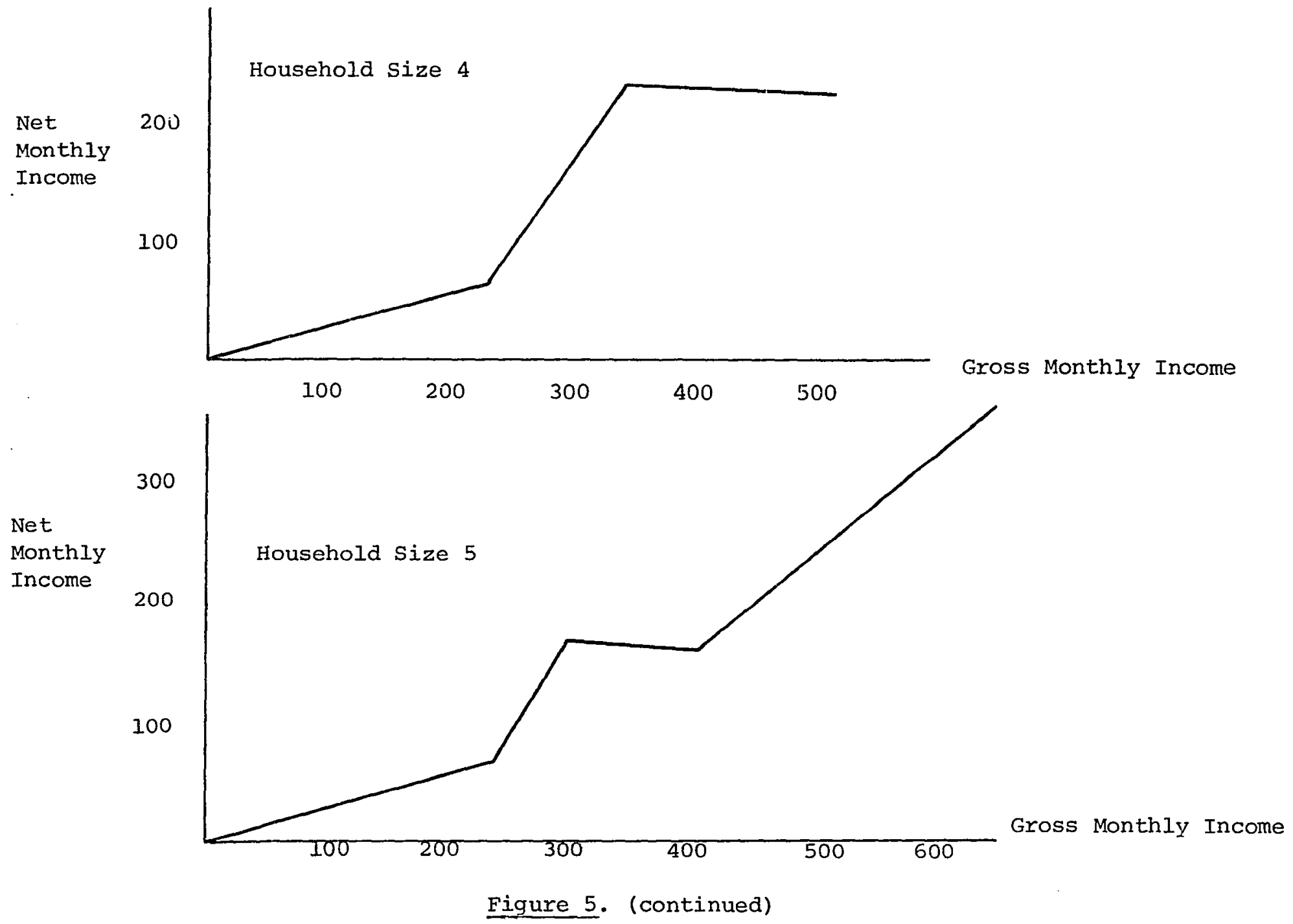




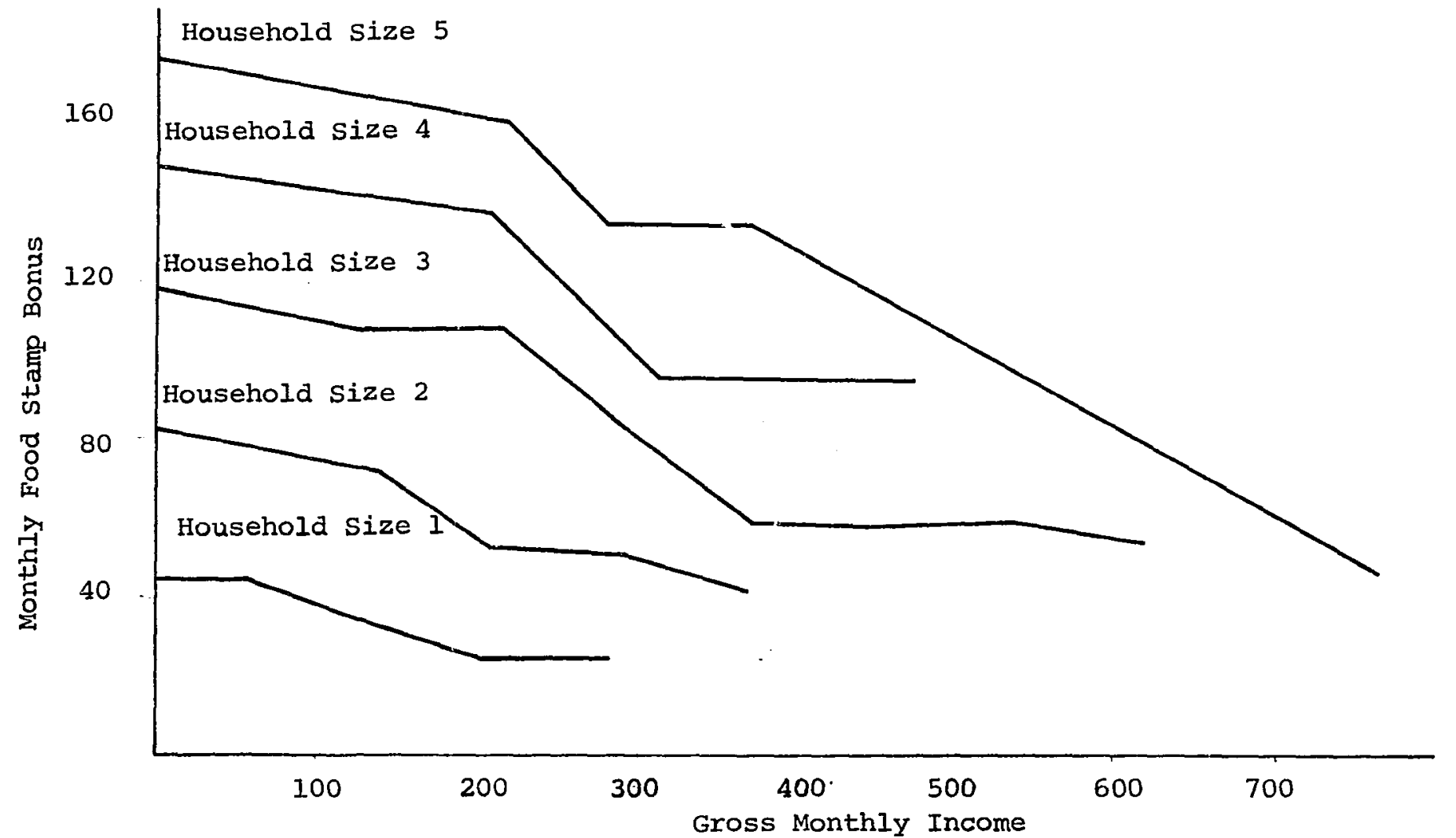

Figure 6. Characteristics of non-public assistance food stamp recipients: gross income and bonus. 
increases, bonuses decrease at a slower rate in the upper income classes.

Table XXXIX contains the incidence of some major deductions from gross income and the reported income sources of households in the survey. About $35 \%$ of the sample reported earnings as their major income source. Deductions for excess shelter payments were permitted virtually every household with the average value of such deductions equalling nearly $\$ 73$ per month. Thus shelter deductions account for $58 \%$ of the $\$ 124$ average monthly difference between net and gross income. While excess shelter deductions were large, the average gross monthly rent paid by sample households was only $\$ 122.84$. The program formula permits the deduction of shelter expenditures in excess of $30 \%$ of income net of all other deductions. This results in households with extremely modest housing expenditures receiving some shelter deduction.: The reward for shelter expenaitures depends upon the income and the size of the household. A two person household with net income of $\$ 103$ per month -- the mean net income for this household size (Table XXXV) -- receives a $\$ 21$ per month additional bonus if it has the $\$ 73$ shelter deduction typical of the sample. Without such a deduction, the household's net income would equal \$176 and it would be required to pay $\$ 44$ for its stamps. With the shelter deduction, it pays only $\$ 23$ for its stamps (Table $\mathrm{xxX}$ ).

Table XI contains the average shelter deductions by household size and income class and Figure 7 plots these deductions against gross monthly income (Table XXXVI). Shelter deductions demonstrate a tendency to increase slightiy with increases in gross income. 
TABIE XXXIX

CHARACTERISTICS OF NON-PUBLIC ASSISTANCE FOOD STAMP RECIPIENTS: DEDUCTIONS FROM GROSS INCOME AND REPORTED INCOME SOURCES, MULTNOMAH COUNTY, OREGON, DECEMBER, $1974^{1}$

Deductions from Gross Income Permitted Sample Households ( $N=498$ )

Type of Deduction

Medical

Child Care

Tuition

Excess Shelter Payments

(Mean Excess Shelter Payment= $\$ 72.72$ per month)

(Mean Gross Rent $=\$ 122.84$ per month)
Number of Households

Permitted Deduction

238

24

70

493 $\underline{\text { Percent }}$

47.8

4.8

14.1

99.0

Reported Income Source. ${ }^{2} \quad$ Number of Households $\quad$ Percent

Social security or SSI

Pension

Earned Income 3

114

22.9

Veterans Benefits

9
173

1.8

Unemployment Compensation

Child Support and/or Alimony

26

34.7

$36 \quad 7.2$

Educational Loans or Scholarships

Strike Benefits

No Reported Income

Unknown or other

22

4.4

$19 \quad 3.8$

$5 \quad 1.0$

$58 \quad 11.6$

36

7.2

TOTAL

498

$100.0^{*}$

*Does not equal 100.0 due to rounding error.

ISource: Random sample of NPA food stamp households, Multnomah County, Oregon, December, 1974. See text for description.

${ }^{2}$ In cases where households had more than one income source, the dominant source was recorded.

${ }^{3}$ Earned income includes wages and income from self-employment. Many recipients, whose major income source was earned income, did not work full time. 
TABLE XI

CHARACTERISTICS OF NON-PUBLIC ASSISTANCE FOOD STAMP RECIPIENTS: EXCESS SHELTER DEDUCTIONS BY HOUSEHOLD SIZE AND INCOME CLASS, MUITNOMAH COUNTY, OREGON, DECEMBER, $1974^{I}$

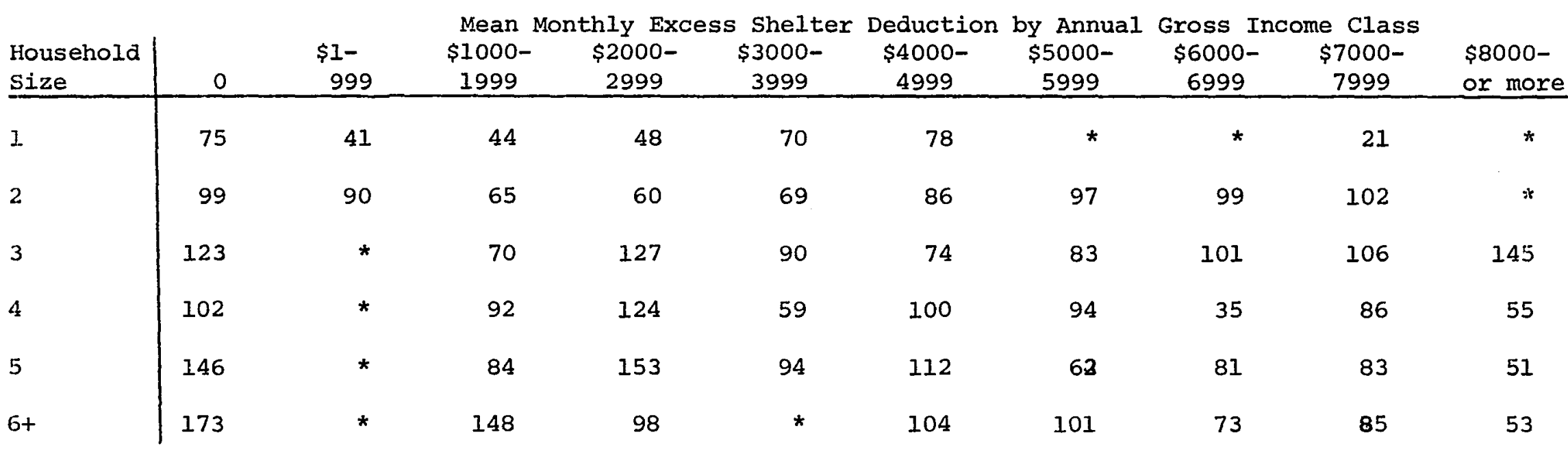

* No observations in this chass.

${ }^{1}$ Source: Random sample of NPA food stamp households, Multnomah County, Oregon, December, 1974. See text for description. 

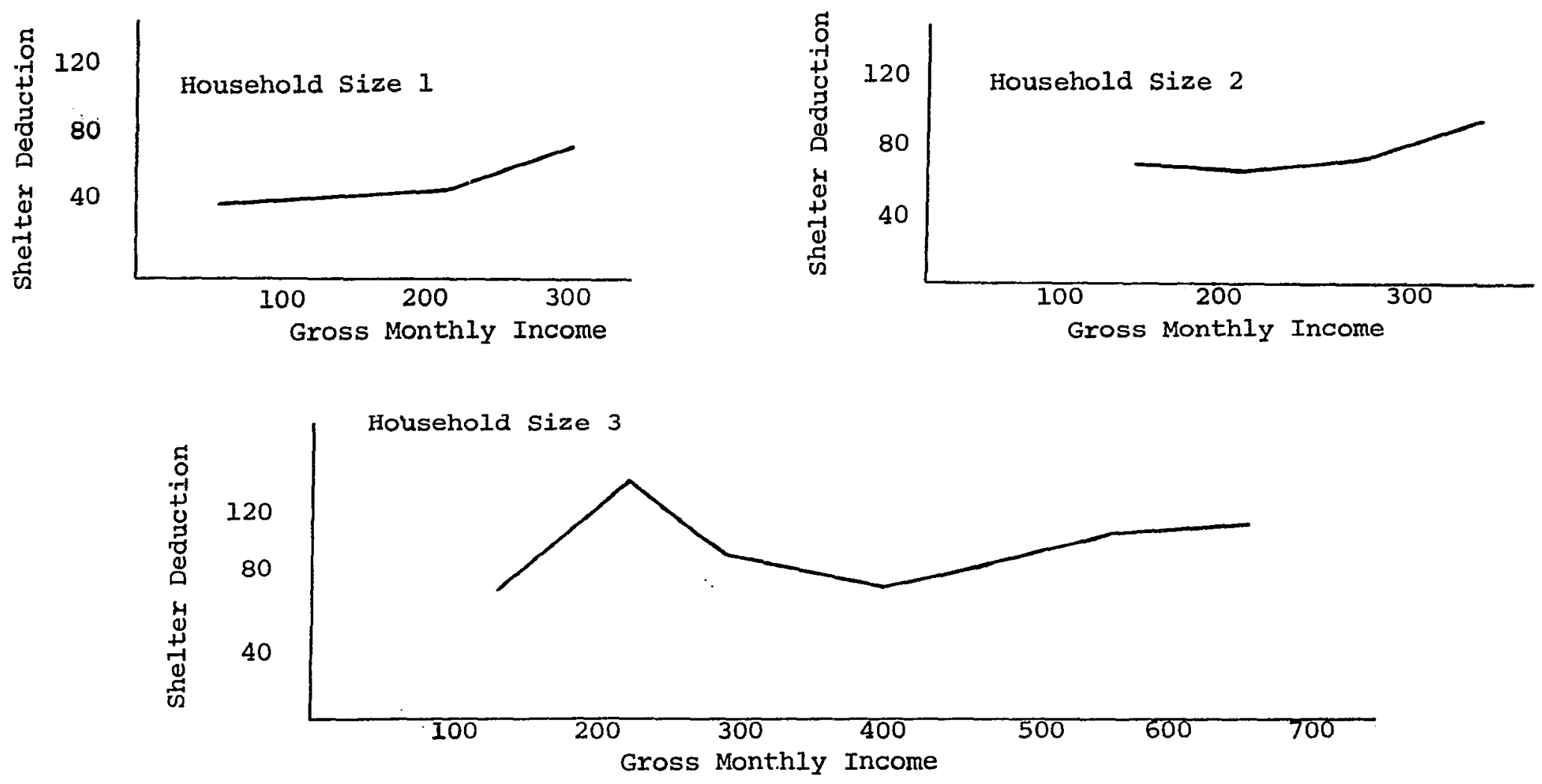

Figure 7. Characteristics of non-public assistance food stamp recipients: gross income and shelter deductions. 

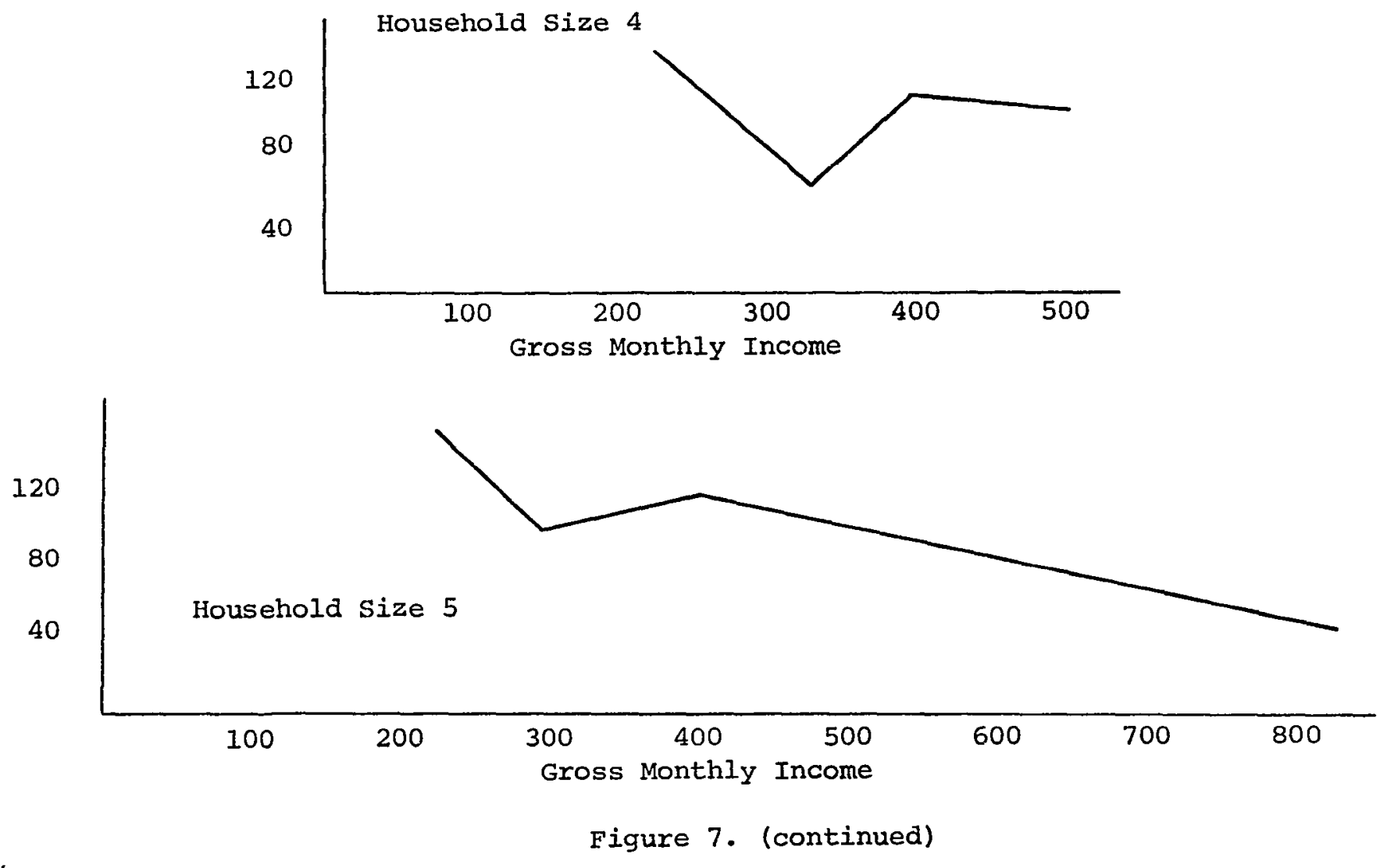
This partially explains why the rate of increase in net income was lower for the higher income classes. Other aspects of the Food Stamp income determination formula also tend to result in proportionately larger deductions from gross income for the upper income eligible. Earned income and work related expenditures are treated far more generously than is income from transfers. Families in the higher income brackets are much more likely to have income from earnings and are therefore likely to have a greater spread between net and gross before shelter deductions. Since shelter deductions are the last to be calculated, the deductions allowed upper income eligible households tend to be multiplicative.

Estimating the Number of Eligible

An effort to estimate the number of eligible, nation-wide, from the Chilton survey data was made by Bickel and Mac Donald. They used the average $.70-.72$ ratio between net and gross income that prevailed in the Chilton survey to derive the maximum gross income limits implied by the net income maximums mandated by the Food stamp program. These implied gross income limits were fitted to the distribution of households by income and household size on a state by state basis to estimate the number eligible on income criteria. Bickel and Mac Donald conclude; that about 33.5 million persons were eligible for Food Stamps in 1974, with 292,441 eligible in Oregon. Nationwide, Bickel and Mac Donald estimated that $31-38 \%$ of the eligible receive Food Stamps while Oregon participation was $39-475$ of the eligible. ${ }^{18}$

${ }^{18}$ Gary W. Bickel and Maurice Mac Donald, op. Cit., pp. 13, 29. 
The results of the NPA survey in Multnomah County suggest that Bickel and Mac Donald seriously underestimate the number of eligible households. Sixty pexcent of the Chilton households were Public Assistant recipients. As discussed above, the treatment of income in the Food stamp program does not favor such households. The .52 ratio between net and gross income found in the county survey is probably more accurate in describing the net/gross spread for those close to the eligibility limits. Figure 5 suggests that even the assumption that net income is $52 \%$ of gross at the upper limits of the program is too conservative. While the average net/gross ratio in the county survey was .52 , the relationship between net and gross was not linear. Figure 7 indicates that net is a smaller proportion of gross in the upper brackets represented in the survey. However, very few sample households were anywhere near the eligibility maximums, thus it was not possible to determine precisely what gross incomes were implied by the Food stamp program's net income limits.

Table XII contains the 1973 Census Bureau low-income thresholds and the Food Stamp net income maximums, by household size, for 1973. The conservative average .52 net/gross income ratio that prevailed in the county survey was used to derive the gross incomes implied by the net income limits for 1973. While the net limits are very close to the povexty thresholds, the implied gross eligibility limits include a large number of non-poor in the eligible population. (The close correspondence between the net income maximums and the poverty thresholds is not surprising since both are based on the USDA economy diet plan). Table xIII shows the result of fitting the implied gross 
TABLE XLI

LOW-INCOME THRESHOLDS FOR NONFARM HOUSEHOLDS AND FOOD STAMP ELIGIBILITY LIMITS, BY HOUSEHOLD SIZE, U.S., 1973

\begin{tabular}{lccc}
$\begin{array}{l}\text { Household } \\
\text { Size }\end{array}$ & $\begin{array}{c}\text { Low-Income } \\
\text { Threshold }\end{array}$ & $\begin{array}{r}\text { Maximum Net An- } \\
\text { nual Income for } \\
\text { Food Stamps }\end{array}$ & $\begin{array}{c}\text { Implied Maximum } \\
\text { Annual Gross In- } \\
\text { come for Stamps }\end{array}$ \\
\hline 1 & $\$ 2,247$ & $\$ 2,136$ & $\$ 4,108$ \\
2 & 2,895 & 2,796 & 5,377 \\
3 & 3,548 & 3,684 & 7,085 \\
4 & 4,540 & 4,476 & 8,608 \\
5 & 5,358 & 5,280 & 10,154 \\
6 & 6,028 & 6,084 & 11,700
\end{tabular}

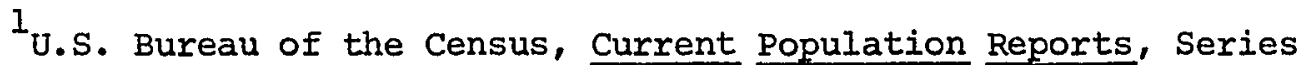
P-60, No. 98, "Characteristics of the Low-Income Population: 1973", (Washington, D.C.: U.S. Government Printing Office, 1975), p. 162.

2 U.S. Department of Agriculture, Food and Nutrition Service, "Food Stanp Program, Current as of July 1, 1972," mimec., pp. 26-7.

3 Estimated by using the average net income/gross income ratio of .52 that prevailed in a random sample of 498 NPA food stamp households in Multnomah County, Oregon in December, 1974. 
income limits in Table XII to the county distribution of households by size and income class in Table Xx. A total of 70,262 households or $40 \%$ of the county population were estimated as eligible for Food Stamps. Of those eligible, only about 15,500 or 208 were actually participating in the program.

Bickel and Mac Donald warn of some major sources of error associated with estimate made in the above manner. Since the Food stamp program has an assets as well as an income test, it is possible that those who qualify on the basis of income are unable to pass the assets screen. The only detailed survey of the value of assets of low-income households dates from 1962. On the basis of this survey, Bickel and Mac Donald conclude that, at most, 218 of those eligible on the basis of income, would be.eliminated by an assets test. 19

Bickel and Mac Donald indicate that a more serious source of bias is the significant undercounting that results from using annual income data to calculate eligibility for a program which determines eligibility on the basis of current monthly income. In reviewing the work of other researchers, they maintain that,

- . the number of normally above-standard households that will fall temporarily below the food stamp eligibility levels in particular months is substantially larger than the opposite number of normally below standard households temporarily rising in some months to above-maximum incomes. 20

Bickel and Mac Donald report that research suggests that undercounting due to the "accounting period" bias is about $37 \%$ for urban households. This undercounting estimate relates to the 12-month equivalent of the

$$
\begin{aligned}
& { }^{19} \text { Ibid. , p. } 15 . \\
& 20_{\text {Ibid., p. } 24 .}
\end{aligned}
$$


number of households eligible in a given year, not to the number of households ever eligible which would be much higher.

If the 218 overestimate due to the assets screen is subtracted from the 37\% "accounting period" underestimate, and the $16 \%$ difference is applied to the results in Table XLII, the estimated number of county eligible jumps to 91,944 households or $46 \%$ of the population. The number of eligible participating drops to 17 percent.

While these estimates are admittedly crude, the conclusion that an extremely large number of nouseholds, including substantial numbers of non-poor, are eligible for Food stamps, is inescapable. While the results of both the Chilton and county surveys indicate that very few of the upper-income eligible are currently participating, the recent legal decisions compelling more vigorous "outreach" activities and the rapid expansion of the NPA share of the program suggest that more upper income eligibles will be drawn in. Willard Renkin, Food stamp Coordinator, Multnomah County, Oregon, indicated that important barriers to NPA participation, in the past, were the characterization of Food Stamps as a "welfare" program and an ignorance on the part of high income eligibles that they could receive benefits. ${ }^{21}$ This ignorarce of eligibility is understandable in view of the complexity of the income determination formula which results in a large difference between net and gross income maximums. Probably few households above the poverty thresholds suspect that they are eligible because the maximum incomes cited in program publicity are always the net income limits. As larger numbers of NPA households enter the program and as

\footnotetext{
$21_{\text {Willard Renkin, op.cit. }}$
} 
TABLE XLII

ESTIMATED NUMBER OF HOUSEHOLDS ELIGIBLE FOR FOOD STAMPS, BY HOUSEHOLD SIZE AND INCOME, MULTNOMAH COUNTY, OREGON, FY 1973

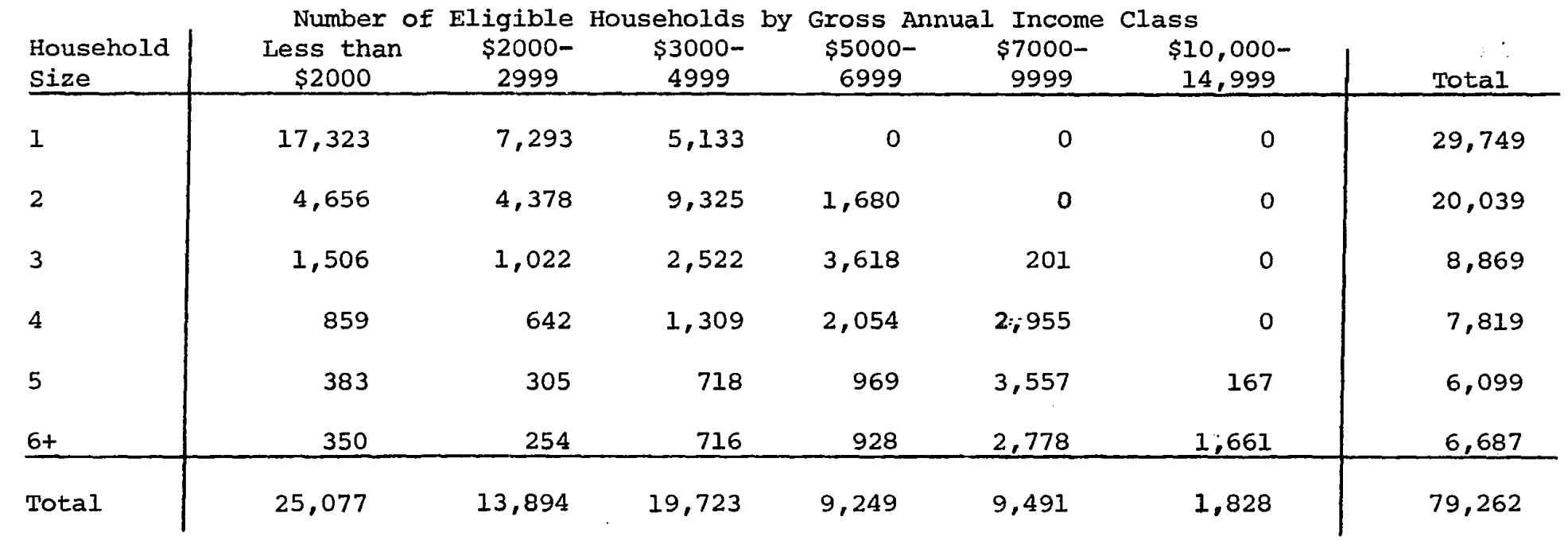

${ }^{1}$ Estimated by applying the Implied Maximum Gross Annual Income for Food Stamps in Table xLI to the county income distribution in Table Xx. It was assumed that the households in a given income class are evenly distributed across that class. 
more detailed program information becomes available, these barriers to the participation of the upper-income eligible are likely to diminish.

\section{Evaluating Food Stamp Subsidies}

Figures 8 and 9 contain applications of the model for evaluating in-kind transfers presented in Chapter IV to the Food stamp Program. Figure 8 demonstrates the effects of the program in Multnomah County in FY 1973 for a two-person NPA household with annual gross income of $\$ 2500$. This household is near the average size and income of the households in the county survey (Table XxxV). The results of the coun-ty survey indicate that this household would have a net monthly income of $\$ 125$ after deductions permitted by the program (Tables XXXVI and $X X X V I I)$. This net income required a recipient payment, $A B$ in Figure 8 , of $\$ 29$ for stamps with a face or market value of $\$ 64, A D$ in Figure 8 (payment schedule is in Table XXIX). The difference between the market value and the recipient's payment of $\$ 35$ is the bonus value of the stamps of the monthly in-kind income provided by the program, BD. On an annual basis, this in-kind transfer is worth \$420. Table XXXII contains expected food expenditures by household size and income class. The $\$ 420$ in-kind income is insufficient to move the household with annual income of $\$ 2500$ to the next income class. Thus the expected food exfenditures for the household, $A C^{\prime}$ in Figure 8 , equal $\$ 92$. Since the expected expenditures for fodd, if the household's income were entirely in cash, exceed the market value of the food stamps by $44 \%$, there are no substitution effects. $C D$ is equal to 0 as the program dues not compel alterations in the consumption pattern preferred by the 


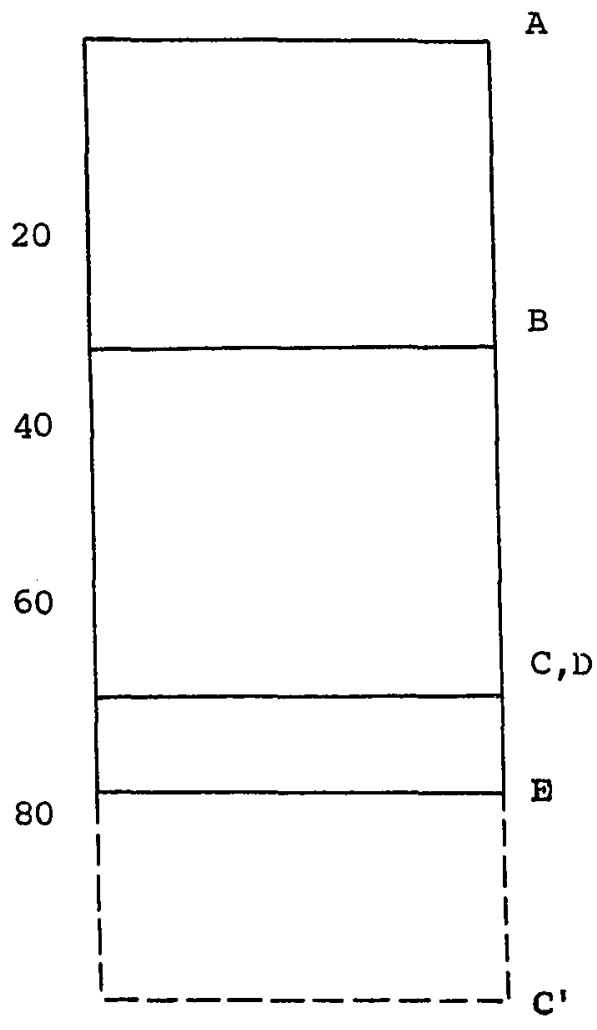

$$
\begin{aligned}
& \text { Gross Monthly Income }=\$ 208 \\
& \text { Net Monthly Income }=\$ 125 \\
& A B=\$ 29=\text { Recipient Payment } \\
& B C= B D=\$ 35=\text { Cash Value of } \\
& \text { Transfer to Recipient }= \\
& \text { In-Kind Income } \\
& A C= A D=\$ 64=\text { Private Benefits= } \\
& \text { Market Value of Food Stamps } \\
& A C '= \$ 92=\text { Expected Food Expendi- } \\
& \text { ture if Income were in Cash } \\
& C D= 0=\text { Substitution Effects } \\
& \mathrm{DE}= \$ 9.71=\text { Administrative Costs } \\
& \mathrm{BE}= \$ 44.71=\text { Total Public Costs } \\
& \mathrm{AE}= \$ 73.71=\text { Total Public and } \\
& \text { Private Costs }
\end{aligned}
$$

Figure 8. Impact of food stamps on two-person household: annual cash income of $\$ 2,500$. 
recipients. The monthly administrative costs per household, DE, of \$9.7I were obtained by dividing the annual administrative costs per household in Table XXVIII by 12. It was assumed that administrative costs are independent of household size as no additional paper work or processing is required for larger households. BE or the total public costs of the program are $\$ 44.71$ of which $78 \%$ os paid out as bonus and $22 \%$ is allocated to administration. $\mathrm{AE}$, the total public and private cost of the transfer is $\$ 73.71$.

Figure 9 contains the same data for a four person NPA household with annual gross income of $\$ 4500$. This gross income was associated with a net monthly income of $\$ 210$ in the county survey (Table XXXVI and XXXVII). At this income level, the required recipient payment, $A B$, is $\$ 59$ for coupons worth $\$ 112, A D$ (Table XXIX). The difference between $A D$ and $A B$ of $\$ 53$ is the cash value of the in-kind transfer, BD. On an annual basis, the transfer is worth $\$ 636$-enough to push the household into the $\$ 5000-5999$ income bracket in terms of Table XXXII. At this income level, the household would be expected to expend $\$ 176$ per month on food, $A C^{\prime}$, if its income were entirely in cash. This is an amount $57 \%$ greater than its food stamp allotment of $\$ 112$. Therefore, there are no substitution effects and $C D=0$. As in Figure 8, DE or administrative expenditures equal $\$ 9.71$. Administration receives $15 \%$ of the total public costs of $\$ 62.71, \mathrm{BE}$, while bonus payments to the recipients account for the remaining $85 \%$. $\mathrm{AE}$, the total public and private cost of the transfer is $\$ 121.71$. Figures 8 and 9 demonstrate that, unlike housing subsidies, food stamps do not succeed in inducing changes in consumption patterns. 


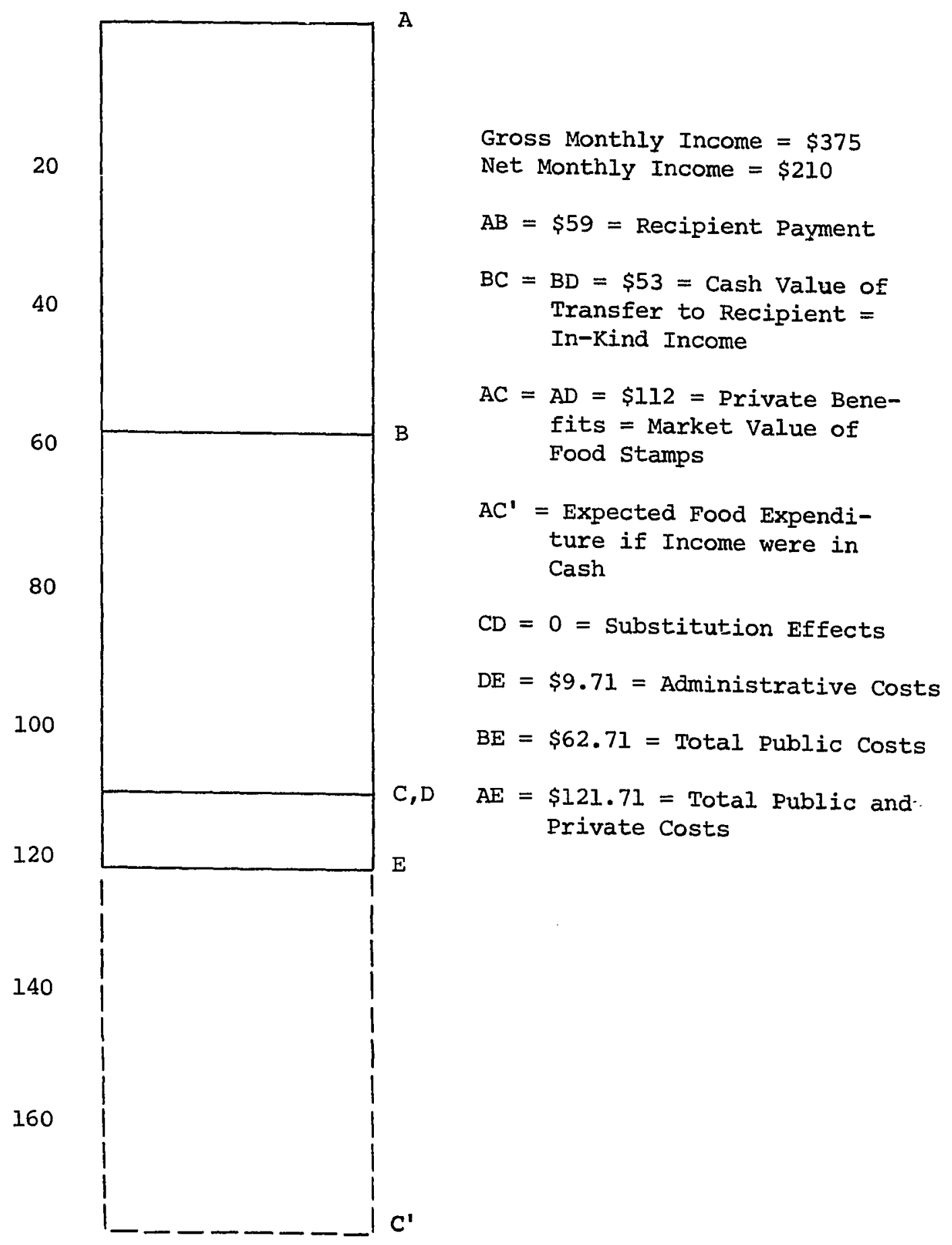

Figure 9. Impact of food stamps on four-person household, annual cash income of $\$ 4,500$. 
As such, the indirect or social benefits of this transfer mode which are related to the presence of substitution effects (Equation 2 in Chapter IV) are zero. As with housing benefits, the definition of social benefits in Equation 2 is very narrow; other conceptualizations would yield other results. Equation 1 in Chapter IV suggests that the minimum social benefits, $\mathrm{SB}^{\mathrm{min}}$, required for an in-kind investment to pay-off, were equal to total costs, $A E$, minus private benefits, AC. In both Figures 8 and $9, \mathrm{SB}^{\mathrm{min}}=\$ 9.71$ per household per month, considerably less than the maximum social benefits demanded by housing programs which induce substitution effects.

\section{Summary}

The data in this chapter indicate that the theoretical and political arguments in favor of in-kind programs, which suggest that changes in consumption patterns produce external benefits, are not relevant to the Food Stamp Program as it currently operates. Benefit levels are not sufficiently large to induce substitution effects, thus recipients treat their in-kind income as cash. This tendency to view food stamps as cash is further reinforced by the variable purchase option which allows participating households to buy as little as onequarter of their monthly allotment. With 208 of public program dollars allocated to administration, the economic logic of giving in-kind rather than in cash is suspect, when recipients are treating the transfer as cash. The data in this chapter also indicate that very large numbers of American households are eligible for food stamps, including many of those not officially designated as poor. While 
program briefits are currently concentrated heavily on the indigent, the open-ended funding for the program and the rapid increase in Non-Public Assistance participation, suggest continued program expansion. The budgetary impact of the program, already expected to exceed $\$ 5$ billion in FY 1975, could be much more substantial in the future. 22

22 "Food Stamp Plan to Provide More," The New York Times, (April 9, 1975), p. 8. 
CHAPTER VII

COÑCLUSIONS

The results of an empirical investigation of the low-income housing and Food stamp programs suggest that in-kind transfers are a politically popular, but inefficient and inequitable method of redistributing income. The hypotheses, proposed in Chapter IV, were confirmed by the data presented in Chapters $V$ and VI.

\section{High Administration and Participation Costs}

High administrative costs were associated with all of the programs examined in this research. The Food Stamp Program in FY 1973 devoted one-fifth of its program dollars to administration. Furthermore, the administrative share of the budget is likely to increase, as a recent change in the cost-sharing formula permits state alu local governments to shift a greater percentage of the financial burden of program administration to the Federal government. With Washington paying more of the bill, the understaffing characteristic of the program is likely to diminish. Under the conservative assumption that administrative costs are still $20 \%$ of the Food stamp budget, about $\$ 1$ billion will be spent on the administration of this single program in FY $1975^{1}$

The administrative share of the low-income housing budget was 1975), p. 8 .

l"Food stamp to Provide More," The New York Times, (April 9, 
even greater: 23-25\% of public leased housing dollars were allocated to administration, while administrative costs were 51-56\% for units owned by the housing authority. High administrative costs are not unique to in-kind programs. AFDC, the major cash welfare program, has also diverted a large proportion of program dollars to bureaucracy. If it is assumed that all needs-tested transfer programs allocate $20 \%$ of their budget to administration (a conservative estimate), then over $\$ 6$ billion was spent in FY 1973 for the management of welfare programs (Table II).

i The major reasons for these high administrative costs, discussed in detail in Chapter I, are program complexity, the diffusion of responsibility between and within levels of government, and the political environment of income redistribution programs which places contradictory demands on policymakers. In addition, the structure of incentives in the public sector does not clearly reward efficient administration. The fundamental disagreement in American society about who deserves assistnace, under what conditions, and in what form, has stimulated a rash of rule-making. Different rules are designed to appeai to different factions in an effort to create consensus for a program. Most programs seek to distinguish between the "worthy" and "unworthy" poor on grounds other than income. The greater the effort to make fine distinctions between the eligible and the ineligible, the greater the complexity and the greater are the administrative problems. While there are certainly many examples of bureaucratic blundering, the basic structure of the welfare system demands high administrative costs from even the most efficient of administrators. In sum, while the nation 
is making an important effort to redistribute income through large public transfer programs, this effort is being undercut by the diversion of many program dollars from the target population to administration.

While all programs require some administrative outlay, the results of the income maintenance experiments suggest that the bureaucratic share could be substantially lower than that associated with current transfer programs. David N. Kershaw, project director of the New Jersey, Denver, and Seattle experiments; estimates that a national cash assistance program would cost less than \$l billion annually to administer (about $\$ 150$ per case). Kershaw's system would include the verification of information at the time of application, periodic auditing of a random sample of all participants, and "audits for cause" of those suspected of fraud. ${ }^{2}$ Thus Kershaw claims that administrative expenditures for a cash system would be roughly comparable to the current cost of administering the Food stamp Program alone. Income maintenance programs, by simplifying eligibility and payment standards and procedures, appear to make possible substantial reductions in the diversion of program dollars to bureaucracy. However, there may be errors associated with projecting national costs from small-scale experiments. It is conceivable that political pressures

2 David N. Kershaw, "Administrative Issues in Establishing and Operating a National Cash Assistance Program," in U.S. Congress, Joint Economic Comittee, Subcommittee on Fiscal Policy, Studies in Public Welfare, Paper No: 5 (Part 3) : Issues in Welfare Administration: Implications of the Income Maintenance Experiments, (Washington, D.C.: U.S. Government Printing Office, 1973). 
for rule proliferation and that a lack of reward for efficiency woulä also come to characterize an income maintenance system.

In addition to high administrative costs, the structure of the American welfare system imposes high information and transaction costs on its intended beneficiaries. The low participation rates in the open-ended Food Stamp Program are evidence that there are significant barriers to the involvement of the eligible. The complicated income determination formulas, characteristic of the Food Stamp Program and most other welfare programs, make it difficult for potential participants to assess their eligibility and/or probable benefits. In addition, program participation frequently demands long waits for services, traveling to take advantage of benefits, aggressiveness in applying for transfers, and/or services in a form which embarass some of the eligible. Potential recipients are confronted with a confusing and inconvenient delivery system which leads many of the eligible to elect not to participate. Ironically, the structure of participacion costs tends to discourage the least controversial subgroups of the target population -- the elderly and disabled.

\section{Substitution Effects}

In-kind transfers enjoy much greater political support than do cash transfers. While difficult to quantify, American public opinion, as reflected in the political syster, has backed the transfer of basic commodities more strongly than it has the redistribution of cash income. In the vocabulary of welfare theory, the data support the existence of "goods-speciric" utility interdependence. Specific ills, like malnu- 
trition and slum housing, rather than poyerty in general, are viewed as imposing social costs on the community. In part, specific deficiencies become the focus of attention because they are more visible and less abstract than poverty in general. Perhaps as crucial, in a culturally heterogeneous nation, transfers of the basic necessities of life are less divisive than are transfers of cash. Many taxpayers suspect that cash transfers would be "wasted" by welfare recipients who are perceived as having values and behavior patterns unlike those of the American mainstream. In-kind transfers are proposed as a means of assisting the poor in a way which is expected to maximize the social benefits of income redistribution. The popular political logic insists that the Food Stamp Program is the preferred perscription for the malnourished while housing programs are most appropriate for the house poor. It is assumed that cash transfers would partially be diveried from the expenditure categories of greatest concern to the donors. In short, in-kind transfers are thought to generate subsitution effects or to insure more socially acceptable consumption patterns than would the transfer of caish.

The results of an empirical evaluation of the Food Stamp and lowincome housing programs reveal that the popular conception of the impact of in-kind programs is based on some erroneous assumptions. A key discovery was that in-kind programs do not always induce substitution effects. A comparison of the food expenditures of Food stamp households with the food consurption patterns of comparable low-income households found that those purchasing their full monthly alloiment of food stamps were not compelled by the program structure to increase 
consumption of food. In addition, the adoption of the variable purchase option permits participating households to determine their own level of food consumption within wide limits. Households purchasing as little as one-quarter of their monthly allotment are granted active status in the program.

In the Food Stamp Program, the strategy has been to cut the transfer pie into small pieces. Relatively meager transfers are provided to a very large numbex of participarts. A convoluted system of script, with 20 of every $\$ 1$ going to administration, has been created under the illusion that the hungry are receiving more food than they would be inclined to purchase for themselves, if provided with equivalent cash subsidies. While the Food stamp Program undoubtedly permits participants to purchase more food than they would in the absence of any subsidy, the evidence is that food stamp recipients use their script as they would increments in cash. The high administrative and participation costs associated with the Food stamp Program do not appear to be compensated for by social benefits different from those which could be obtained from cash transfers. In contrast, the low-income housing programs were found to induse the kinds of alterations in consumption patterns expected of inkind transfers. The housing pie is cut into large pieces for a much smaller number of participating households. As a result, those fortunate enough to gain acmission consume considerably more housing than they would ff given a comparable cash aubsidy. Since there are so few pieces of pie, $95 \%$ of those eligible are unable to participate. 
To the extent that external diseconomies are associated with the housing consumption patterns of the entire eligible population, these external diseconomies are only slightly diminished by programs which leave the bulk of the target group untouched. While housing programs generate substitution effects, their price is high both in terms of administrative costs and the inequitable exclusion of the eligible from program benefits through the restriction of supply.

In sum, while the Food stamp and low-income housing programs represent opposite strategies in terms of the benefits available per household and the number of households permitted to participate, all programs were found to be deficient in significantly altering the consumption patterns of the eligible population as a whole. Inkind programs do produce benefits. However, it is questionable whether these benefits are greater than those which would result from equivalent cash subsidies or whether the benefits produced are greater than their costs.

\section{Equity}

The current welfare system does not provide those with similar socio-economic characteristics with similar benefits. Housing transfers are available to only a small number of eligible. The complex income determination formula employed in the food stamp program results in a considerable variation in the benefits paid to households of similar size and income. Some program benefits are not available in all geographic locations. While the potential cumulative benefits 
available to poor households, under the maze of welfare programs, is very large, the actual distribution of public transfers varies enormously between equally needy households. Very few households receive all of the benefits to which they are legally entitled.

The current distribution of benefits in both the Food stamp and low-income housing programs was found to be heavily skewed toward the poor. 'However, official definitions of eligibility were found to include many non-poor. In Multnomah County, Oregor, $37 \%$ of the households were eligible for housing assistance and $46 \%$ were eligible for food stamps. While the tight supply of housing transfers inhibits participation growth, the potential for expansion in the openended Food Stamp Program is enormous. By June of 1975, it is estimated that $10 \%$ of the American population will be receiving food stamps. ${ }^{3}$ The wisdom of a policy which would take middle-class tax dollars and distribute them to lower-middle class recipients in the form of script -- after allocating a sizable proportion to administration -- is suspect. However, the greater the diffusion of benefits and the more middle-class the recipients, the greater is the apparent political potency of a program.

\section{Non-Economic Issues}

While the economic logic of in-kind programs is not compelling,

3"Food stamp Plan to Provide More," op. cit.

${ }^{4}$ David A. Stockman, "The Social Pork Barrel," The Public Interest, No. 39, (Spring, 1975), pp. 3-30. 
the political logic behind such transfers remains powerful. When policymakers attack in-kind programs, they tend to focus on inadequate benefit or participation levels or on glaring administrative malfunctions. There appears to be very little interest in critically evaluating the transfer mode itself or in empirically validating the assumptions underlying the rhetoric promoting in-kind programs. Supporters of policies which redistribute income may rationally fear that attacks on the basic structure of popular transfer programs would resilt in a reduction in the benefits available to the poor rather than to the creation of superior programs. The pressure to enlarge the public welfare pie and to liberalize eligibility requirements has produced enormous program expansion. This expansion has occurred because the reward structure in the political system encourages policymakers to respond to the pressures emanating from the "publics" associated with established programs, rather than to respond to the implications of academic analyses.

In this research, a theoretical framework which emphasizes the economic impact of in-kind transfers has been employed. However, considerable attention has been devoted to the political environment. The development of the utility interdependence paradigm in welfare economics permits the integration of political and economic yariables and this integration has been stressed in this work. Despite the high costs found to be associated with in-kind transfers, it is possible that public preferences for this mode are so strong and the antipathy to cash transfers so great that the total benefits associated with 
in-kind transfers may be worth their costs. However, this investigation has revealed that the political rhetoric in favor of in-kind transfers is based upon illusions as to the effect of such transfers on the target population. To the extent that policymaking is a rational process, the actual impact of program operations ought to enter the public calculus.

The programs selected for analysis were evaluated solely in relationship to their adequacy as mechanisms for the redistribution of income and their effectiveness in stimulating the consumption of designated goods. In-kind programs have not been analyzed in terms of other goals. This narrow perspective omits some objectives which have been important to program advocates. While the Food stamp Program has not had explicit goals othex than the transfer of income and the encouragement of food consumption, housing programs have been considerably broader in scope. For example, the ability of public ownership or management to upgrade neighborhoods when the structure of incentives in the private sector inhibits the necessary cooperation between private owners, has not been discussed. The efficacy of housing programs in facilitating the delivery of services to multiproblem families and the success of housing authorities in proviaing unique accomodations for the elderly and disabled has not been assessed. The contributions of housing programs to integration have also been ignored. In sum, all of the goals of in-kind transfer programs have not been considered and the conclusions regarding the effectiveness of in-kind transfers are relevant only to the specific goals em- 
phasized in the analytical framework. To the extent that in-kind transfers are primarily intended to redistribute income and alter the consumption patterns of the target population, they were found to be inefficient and inequitable. 
REEERENCES

Books and Articles

Aaron, Henry J. Shelter and Subsidies: Who Benefits from Federal Housing Policies?, Washington, D.C.: The Brookings Institution, 1972 .

Aaron, Henry J. Why is Welfare so Hard to Reform?, Washington, D.C.: The Brookings Institution, 1973 ,

Arrow, Kenneth J. Social Choice and Individual Values, 2nd edition, New Hawen: Yale University Press, 1963.

Bator, Francis M. "The Simple Analytios of Welfare Maximization," The American Economic Review, XLVII, Marchmin957; pp. 22-59.

Baumol, William J. "On the Social Rate of Discount," The American Economic Review, LVIII, September, 1968, pp. 788-802.

Bergson, Abram. "On Social Welfare Once More," in Abram Bergson, Essays in Normative Economics, Cambridge: The Belknap Press, 1966, pp. 51-90.

Buchanan, James M. "What Kind of Redistribution Do We Want?," Economica, May, 1968, pp. 185-204.

Buchanan, James M. and Tullock, Gordon. The Calculus of Consent, Ann Arbor: The University of Michigan Press, 1962.

Cavala, Bill and Wildavsky, Aaron. "The Political Feasibility of Income by Right," Public Policy, XVIII, Spring, 1970, pp. 321354 .

Cuomo, Mario M. Forest Hills Diary: The Crisis of Low Income Housing, New York: Random House, 1974.

Daly, George and Giertz, Fred. "Benevolence, Malevolence and Lconomic Theory," Public Choice, XIII, Fall, 1972, pp. 1-19.

Daly, George, and Giertz, Fred. "Welfare Economics and Welfare Reform," The American Economic Review, LXII, March, 1972, pp. 131-138.

De Leeuw, Frank. "The Demand for Housing:... A Review of Cross-Section Evidence," The Review of Economics and Statistics, IIII, February, 1971, pp. 1-10. 
De Leeuw, Frank. Opexating Expenses in Public Housing, 1968-71, Washington, D.C.: The Urban Institute, 1973.

De Leeuw, Frank and Ekanem, Nkanta. ."Time Lags in the Rental.Housing Market," Urban Institute Reprint \#159-112-19, February, 1974.

De Salvo, Joseph S. "A Methodology for Evaluating Housing Programs," Journal of Regional Science, XI, August, 1971, pp. 173-185.

Downs, Anthony. An Economic Theory of Democracy, New York: Harper and Row, 1957.

Downs, Anthony. Inside Bureaucracy, Boston: Little, Brown and Co., 1966.

Fried, Edward R., Rivlin, Alice M., Schultze, Charles L., and Teeters, Nancy H. Setting National Priorities: The 1974 Budget, Washington, D.C.: The Brookings Institution, 1973.

Friedman, Lawrence M. Government and Slum Housing: A Century of Frustration, Chicago: Rand Mc Nally and Co., $1 \overline{9} 6 \overline{8}$.

Garfinkle, Irwin. "Is In-Kind Redistribution Efficient?," The Quarterly Journal of Economics, May, 1973, pp. 320-330.

Handler, Joel F. and Hollingsworth, Ellen Jane. The "Deserving Poor": A Study of Welfare Administration, Chicago: Markham Publishing Co., 1971.

Hochman, Harold M. "Individual Preferences and Distributional Adjustments," The American Economic Review, LXII, May 1972, pp. 353360 .

Hochman, Harold M. and Rodgers, James D. "Pareto Optimal Redistribution," The American Economic Review, LVIII, September, 1969, pp. $542-\overline{557}$.

Hochman, Harold M. and Rodgers, James D. "Pareto Optimal Redistribution: Reply," The American Economic Review, LIX, December, 1970, pp. 997-1002.

Hochman, Harold M. and Rodgers, James D. "Utility Interdependence and Income Transfers through Charity," in Kenneth E. Boulding, Martin Pfaff, and Anita Pfaff, (editors), Transfers in an Ur-:. banized Economy: Theories and Effects of the Grants Economy, Belmont, Ca.: Wadsworth Publishing Co., Inc., 1973, pp. 63-77. 
Kristof, Frank S. "Federal Housing Policies: Subsidized Production, Filtration, and Objectives; Part $I$ and Part II," : Irand Econo mics, XLVIII, Noyember, 1972, pp. 309-320, and XIIX, May, 1973, pp. 163-174.

Lerman, Robert I. and Townsend, Alair.A. .."Conflicting Objectives in Income Maintenance Programs," The American Economic Review, Papers and Proceedings, LXIV, May, 1974, pp. 205-211.

Levitan, Sar.A...and Cleary,.Karen. Old Wars Remain Unfinished: The Veteran Benefits System, Baltimore and London: The Johns Hopkins University Press, 1973.

Lindblom, Charles E. The Policy-Making Process, Englewood Cliffs, N.J.: : Prentice-Hall, 1968.

Lowry, Ira S. "Filtering and Housing Standards," Land Economics, XXXVI, November, 1960, pp. 362-370.

Mishan, E.J. "The Futility of Pareto-Efficient Distribution," The American Economic Review, IXXI, December, 1972, DE. 971-976.

Moynihan, vaniel P. The Politics of a Guaranteed Income: The Nixon Administration and the Family Assistance Plan, New York: Vintage Books, 1973.

Musgrave, Richard A. "Pareto Optimal Redistribution: Comment," The American Economic Review, LX, December, 1970, pp. 991-993.

Musgrave, Richard A. "Provision for Social Goods," in J. Margolis and H. Guitton, (eવ̛̣itors), Public Economics, New York: St. Martin's Press, 1969.

Musgrave, Richard A. and Musgrave, Peggy B. Public Finance in Theory and in Practice, New York: Mc Graw-Hill, 1973.

Muth, Richard F. Public Housing: An Economic Evaluation, Evaluative Studies 5, Washington, D.C.: American Enterprise Institute for Public Policy Research, March, 1973.

Olsen, Edgar 0..." A Competitive lheory of the Housing Market,". The American Economic Review, LIX, September, 1969, pp. 612-621.

Olsen, Edgar 0. "A Normative Theory of Transfers," Public Choice," VI, Spring, 1969.

Olsen, Edgax.0. "Some..Theorems.in the Theory of Efficient Transfers," Journal of Political Econom; IXXIX, January, February, 1971, pp. 166-176. 
Orr, Larry. "The Welfare Economics of Housing for the Poor,". Institute for Research on Poyerty Discussion Paper 33-69, Madison, : Wis.: The University of Wisconsin, December, 1968.

Pauly, Mark.V. "Efficiency incithe Provision of Consumption Subsidies," Kyklos, XXIII, 1970, pp. 33-57.

Polinsky, A. Mitchell. "Shortsightedness and.Nonmarginal Pareto Optimal Redistribution," The American Economic Review, IXI, December, 1971, pp. 972-979.

Rainwater, Lee. $\therefore$ what Money Buys: Inequality and the Social Meaning of Income, New York: Basic Books, Inc., 1974.

Ripley, Randall B. "Legislative Bargaining and the Food Stamp Act, 1964," in Frederic N. Cleaveland and Assocaites, Congress and Urban Problems, Washington, D.C.: The Erookings Institution, 1969.

Sadacca, Robert, Loux, Suzanne B., Isler, Morton I., and Drury, Margaret J. Management Performance in Public Fousing, Washington, $\therefore$ D.C.: The Urban Institute, January, 1974.

Segal, Judith A. Food for the Hungry: The Reluctant Society, Baltimore and London: The Johns Hopkins University Press, 1970.

Smolensky, Eugene. "Public Housing or Income Supplements -- the Fconomics of Housing. for the Poor," The American Institute of Planners Journal, March, 1968, pp. 94-101.

Solomon, Arthur P. Housing the Urban Poor, Cambridge: The MIT Press, 1974.

Steiner, Gilbert $Y$. The State of Welfare, Washington, D.C.: The Brookings Instituition, 1971 .

Stockman, Da.vid A. "The Social Pork Barrel," The Public Interest, No. 39, Spring, 1975, pE. 3-30.

Thurow, Lester C. "Cash Versus In-Kind Transfers," The American Economic Reyiew: Rapers and Proceedings, IXIV, May, 1974, pp. 190-195.

Tobin, .James. "On Limiting the Domain of Inequality,". The Journal of Law and Economics, 1970, pp. 263-277.

Von Furstenberg, George:M. and Mueller, Dennis: C. "The Pareto Optimal Approach to Income Redistribution: A Fiscal Application," The American Economic Review, LXI, September, 1971, pp. 628-637. 
Weisbrod, Burton A. "Collective Action and the Distribution of Income," in Robert Haveman and Julius Margolis, Public Expenditures and Policy Analysis, Chicago: Markham Publishing Co., 1970, pp. 117-141.

Weisbrod, Burton A. "Income Redistribution Effects and BenefitCost Analysis," in Samuel Chase, Jr., (editor), Problems in Public Expenditure Analysis, Washington, D.C.: The Brookings Institution, 1968, pp. 177-209.

Welfeld, Irving H. America's Housing Problem: An Approach to its Solution, Evaluative Studies 10, Washington, D.C.: The American Enterprise Institute for Public Policy Research, Qatober, 1973.

Wildavsky, Aaron. The Politics of the Budgetary Process, Boston: Little, Brown, and Co., 1964 .

Government Publications

Bickel, Gary $\mathrm{W}$ and Mac Donald, Maurice. "Participation Rates in the Food Stamp Program: Estimated Levels for 1974, By State," in U.S. Senate, Select Committee on Nutrition and Human Needs, Report on Nutrition and Special Groups, Appendix B to Part I-Food Stamps, Washington, D.C.: U.S. Government Printing Office, 1975.

De Leeuw, Frank. "The Housing Allowance Approach," in U.S. House of Representatives, Committee on Banking and Currency, Subcommittee on Housing Panels, Papers Submitted to the Subcommittee on Housing Panels on Housing Production, Housing Demand and Developing a Suitable Living Environment, Washington, D.C.: U.S. Government Printing Office, 1971, pp. 541-554.

De Leeuw, Frank and Leaman, Sam H. "The Section 23 Leasing Program," in U.S. Congress, Joint Economic Cormittee, The Economics of Federal Subsidy Programs, Part 5 -- Housing Subsidies, Washington, D.C.: U.S. Government Printing Office, 1972, pp. 642-659.

Galm, Sharon. "Welfare -- An Administrative Nightmare," in U.S. Congress, Joint Economic Committee, Subcomittee on Fiscal Policy, Studies in Public Welfare, Paper No. 5 , (Part 1), Issues in Welfare Administration; Washington, D.C.: U.S. Government Printing Office, 1972.

Gillim, Marion Hamilton. "An Economic Analysis of Federal Food Subsidies," in U.S. Congress, Joint Economic Committee, Subcommittee on Priorities and Economy in Government, The Economics of Federal Subsidy programs -- Part 8 -- Selected Subsidies: Washington, D.C.: U.S. Government Printing Office, 1974. 
Handler, Joel F. "Federal-State Interests in Welfare Administration," in U.S. Congress, Joint Economic Committee, Subcommittee on Fiscal Policy, Studies in Public Welfare, Paper No. 5 , (Part 2 ), Issues in Welfare Administration: Intergovernmental Relationships, Washington, D.C.: U.S. Government Printing Office, 1973.

Hausman, Leonard J. "Cumulative Tax Rates in Alternative Income Maintenance Systems," in U.S. Congress, Joint Economic Committee, subcommittee on Fiscal Policy, Studies in Public Welfare, Paper No. 4, Income Transfer Programs: How They Tax the Poor, Washington, D.C.: U.S. Government Printing Office, 1972.

Kershaw, David N. "Administrative Issues in Establishing and Operating a National Cash Assistance Program," in U.S. Congress, Joint Economic Comittee, Subcommittee on Fiscal Policy, Issues in Welfare Administration: Implications of the Income Maintenance Experiments, Paper No. 5, (Part 3), Washington, D.C.: U.S. Government Printing Office, $\overline{1973 .}$

Kummerfeld, Donald D. "The Housing Subsidy System," in U.S. House of Representatives, Committee on Banking and Currency, Subcommittee on Housing Panels, Papers Submitted to the Subcommittee on Housing Panels on Housing Production, Housing Demand, and Developing a Suitable Living Environment, Washington, D.C.: U.S. Government Printing office, 1971.

Kunreuther, Howard. "Why the Poor May Pay More for Food: Theoretical and Empirical Evidence," in U.S. Senate, Select Committee on Nutrition and Human Needs, Reference Material to Part 1, Food Price Changes, 1973-74, Washington, D.C.: U.S. Government Printing Office, 1974.

Ierman, Robert I. "Inventive Effects in Public Income Transfex Programs," in U.S. Congress, Joint Economic Committee, Subcommittee on Fiscal Policy, studies in Public Welfare, Paper No. 4 , Income Transfer Programs: How They Tax the Poor, Washington, D.C.: U.S. Government Printing Office, 1972 .

Lowry, Ira S. "Housing Assistance for Low-Income Families: A Fresh Approach," in U.S. House of Representatives, Committee on Banking and Currency, Subcomittee on Housing Panels, Papers Submitted to the Subcommittee on Housing Panels on Housing Prcduction, Housing Demand and Developing a Suitable Living Environment, Washington, D.C.: U.S. Government Printing Office, 1971.

Iund, Mc Cutcheon, Jacobson, Inc. "Analyses of Publicly Assisted Low-Income Family Housing Requirements, Portland, Oregon, 197175," Report prepared for the Housing Authority of Portland, January, 1972 . 
Multnomah County Budget Fiscal Year 1974-1975, Portland: Multnoinah County, 1974 .

Oregon, State of, Legislative Fiscal Officer, Analyses of the Governor's 1973-75 Budget Report, Salem: state of Oregon, 1973 .

Oregon, State of, Public Welfare Division, Department of Human Resources, Public Welfare in Oregon, XXXVII-XXXIX, 1972-74.

Schechter, Henry B. "Federal Housing Subsidy Programs," in U.S. Congress, Joint Economic Committee, Subcomittee on Riscal Polciy, The Economics of Federal Subsidy Programs, Part 5, Housing Subsidies, Washington, D.C.: U.S. Government Printing office, 1972.

Shiskin, Julius. "The 1972-73 Consumer Expenditure Survey -- Some First-Year Diary Results," U.S. Department of Labor, Bureau of Labor Statistics, April 16, 1975, mimeo.

Sitkin, Peter E. "Welfare Law: Narrowing the Gap between Congressional Policy and Iocal Practice," in U.S. Congress, Joint Economic Committee, Subcommittee on Fiscal Policy, Studies in Public Welfare, Paper No. 5 (Part 2), Issues in Welfare Administration: Intergovernmental Relationships, Washington, D.C.: U.S. Government Printing Office, 1973.

Smolensky, Eugene and Gomery, J. Douglas. "Efficiency and Equity Effects in the Benefits from the Federal Housing Program in 1965," in U.S. Congress, Joint Economic Comnittee, Subcommittee on Priorities and Economy in Government, Benefit-Cost Analyses of Federal Programs, Washington, D.C.: U.S GovernPrinting office, 1973:

Sternlieb, George. "Abandonment and Rehabilitation: What is to be Done?" in U.S. House of Representatives, Comittee on Banking and Currency, Subcomittee on Housing Panels, papers Submitted to the Subcommittee on Housing Panels on Housing Production, Housing Demand, and Developing a suitable living Environment, Washington, D.C.: U.S. Government Printing office, 1971 .

Storey, James R. Studies in Public Welfare, Paper No. 1: Public Income Transfer Programs: The Incidence of Multiple Benefits and the Issues Raised by their Receipt, a study prepared for the use of the U.S. Congress, Joint Esonomic Committee, Subcommittee on Fiscal Policy, Washington, D.C.: U.S. Government Printing office, 1972. 
U.S. Government. The Budget of the U.S. Government, Appendix, FY 1965 - 1975, Washington, D.C.: U.S. Government Printing Office, 1964 - 1974.

U.S. Bureau of the Census. Census of Housing: 1970, Vol. 1 Housing Characteristics for states, Cities and Counties, Part 39, Oregon, Washington, D.C.: U.S. Government Printing Office, 1972 .

U.S. Bureau of the Census. Census of Housing: 1970, General Housing Characteristics, Final Report HC (1)-Al U.S. Sumary, Washington, D.C.: U.S. Government Printing Office, 1971.

U.S. Bureau of the Census. Census of Population: 1970, Detailed Characteristics, Final Report PC (1)-D39 Oregon, washington, D.C.: U.S. Government Printing Office, 1972.

U.S. Bureau of the Census. Census of population: 1970, General Social and Economic Characteristics, Final Report PC (1)C39, Washington, D.C.!' U.S. Government Printing office, 1972.

U.S. Bureau of the Census. Census of population and Housing: 1970, Census Tracts, Final Report PHC (1)-165 Portland, Oreg.-Wash., SMSA, Washington, D.C.: U.S. Government Printing Office, 1972.

U.S. Bureau of the Census. Current Population Reports, Series P-60, No. 91, "Characteristics of the Low-Income Population: 1972," Washington, D.C.: U.S. Government Printing Office, 1973.

U.S. Bureau of the Census, Current Population Reports, Series P-60, No. 97, "Money Income in 1973 of Families and Persons in the U.S.," Washington, D.C.: U.S. Government Printing Office, 1975.

U.S. Bureau of the Census. The statistical Abstract of the U.S., 95th edition, published as 1975, The U.S. Factbook, The American Almanac, New York: Grosset and Dunlap, 1975.

U.S. Congress, Joint Economic Committee, Subcomittee on Fiscal Policy, Problems in Administration of Public Welfare Programs, hearings, Washington, D.C.: U.S. Government Printing Office, 1972.

U.S. Congress, Joint Economic Committee, Subcommittee on Fiscal Policy, Studies in Public Welfare, Paper No. 2, Handbook of Public Income Transfer Programs, Washington, D.C.: U.S. Government Printing Office, 1972 . 
U. S. Congress, Joint Economic Committee, Subcomittee on Fiscal Policy, Studies in public Welfare, Paper No. 6 , How Public Welfare Benefits are Distributed in Low Income Areas, Washington, D.C.: U.S. Government Printing Office, 1973.

U. S. Congress, Joint Economic Committee, Subcommittee on Fiscal Policy, Studies in Public Welfare, Additional Material for Paper No. 6: How Public Welfare Benefits are Distributed in Iow Income Areas, Washington, D.C.: U.S. Government Printing office, 1973.

U. S. Congress, Joint Economic Committee, Subcomittee on Fiscal Policy, Studies in Public Welfare, Paper No. 15, Welfare in the 70's: A National Study of Benefits Available in 100 Iocal Areas, Washington, D.C.: U.S. Government Printing Office, 1974.

U. S. Congress, Joint Economic Committee, Subcommittee on Fiscal Policy, Studies in Public Welfare, Paper No. 17, National Survey of Food stamp and Food Distribution Program Recipients: A Sumary of Findings on Income Sources and Amounts and Incidence of Multiple Benefits, Washington, D.C.: U.S. Government printing office, 1974.

U. S. Congress, Joint Economic Committee, Subcomittee on Priorities and Economy in Government, Housing Subsidies and Housing Policy, Washington, D.C.: U.S. Government Printing office, 1973.

U. S. House of Representatives, Subcommittee of the Committee on Appropriations, Departments of Labor and Health, Education and Welfare Appropriations for 1975, Part 6, Departiment of

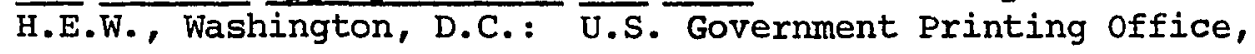
1974.

U. S. Senate, Committee on Finance, Social Services Regulations: Hearings, Part I: HEW Testimony and Part II: Public Witnesses and Written Testimony, Washington, D.C.: U.S. Government Printing office, 1973.

U. S. Senate, Select Committee on Nutrition and Human Needs, Food Price Changes, 1973-74 and Nutritional Status, Washington,

D.C.: U.S. Government Printing Offire, 1974.

U. S. Senate, Select Committee on Nutrition and Human Needs, Food Program Technical Amendments: A Working Paper, Washington, D.C.: U.S. Government Printing Office, 1974 .

U. S. Senate, Select Comittee on Nutrition and Human Needs, Hearings on Nutrition and Human Needs. Part 2 -- USDA, HEW, and OEO Officials, Washington, D.C.: U.S. Government Printing Orfice, 1969. 
U. S. Senate, Select Committee on Nutrition and Human Needs, Hearings: Nutrition and Human Needs -- 1971, Part 3, Food Stamp Regulations, Washington, D.C.: U.S. Government Printing Office, 1971.

U. S. Senate, Select Committee on Nutrition and Human Needs, Hearings: Nutrition and Human Needs - 1972, Part 3B, Unused Food Assistance Funds: Food stamps; Administration Witnesses, Washington, D.C.: U.S. Government Printing Office, 1972.

U. S. Senate, Select Committee on Nutrition and Human Needs, "Hunger 1973". and Press Reaction, Washington, D.C.: U.S. Government Printing office, 1973.

U. S. Senate, Select Committee on Nutrition and Human Needs, National Nutrition Policy Study: Report and Recommendations -- VIII, Washington, D.C.: U.S. Government Printing Office, 1974.

U. S. Senate, Select Committee on Nutrition and Human Needs, Reference Material to Part I Food Price Changes 1973-74, Washington, D.C.: U. S. Government Printing Office, 1974 .

U. S. Department of Agriculture, Food and Nutrition Service, "Food Stamp Program," (current as of July 1, 1972) pamphlet.

U. S. Department of Agriculture, Food and Nutrition Service, "Food Stamp Program; Statistical Summary of Operations," 1972-1975, mimeos.

U. S. Department of Commerce, 1973 Business Statistics, 19th Biennial Edition, Washington, D.C.: U.S. Government Printing office, 1973.

U. S. Department of Health, Education, and Welfare, Social and Rehabilitation Service, Disposition of Public Assistance Cases Involving Questions of Fraud, FY 1972, DHEW Publication No. (SRS) 74-03256, NCSS Report E-7, (FY-72), June 19, 1973.

U. S. Department of Health, Education and Welfare, Social and Rehabilitation Service, Funds, by Source, Expended for Public Assistance Payments and for Administration, Services and Training,

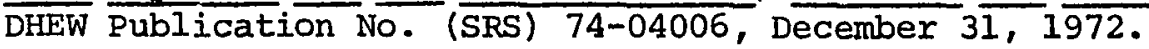

U. S. Department of Housing and Urban Development, 1972 HUD Statistical Yearbook, Washington, D.C.: U.S. Government Printing Office, 1974.

U. S. Department of Irabor, Bureau of Labor Statistics. "Autumn 1973 Urban Family Budgets and Comparative Indexes for Selected Urban Areas," June 16, 1974, mimeo. 
U. S. Department of Labor, Bureau of Labor Statistics, Consumer Expenditures and Income: Cross-Classification of Family Characteristics, Urban U.S., 1960-61, Supplement 2-Part $A$ to BLS Report 237-38, July, 1964.

U. S. Department of Labor, Bureau of Labor Statistics, Handbook of Labor Statistics, 1973, Washington, D.C.: U. S. Government Printing Office, 1973.

U. S. General Accounting Offjce, Report to the Congress: Problems in Attaining Integrity in Welfare Programs, B-164031 (3), March 16, 1972.

Von Furstenberg, George M. "The Distribution of Federally Assisted Rental Housing Services by Regions and States," in U.S. Congress, Joint Economic Committee, The Economics of Federal Subsidy Programs, Part 5 -- Housing Subsidies, Washington, D.C.: U.S. Government Printing Office, 1972.

Newspaper Articles

"Food Stamp Fund Freed by Judge," The New York Times, October 14, 1974 , p. 19.

"Food Stamp Iines Abate in Arizona," The New York Times, December 27, 1974, p. 27.

"Food Stamps and the Future," The Wall Street Journal, January 15, 1975, p.10.

"Food Stamps Hit 19.1 Million Mark," The New York Timas, May 4, 1975 , p. $44 \mathrm{~B}$.

Gumpert, David. "On the Dole: Because of Inflation, Middle-Class Families Join Food-stamp Rolls," The Wall Street Journal, December 20, 1974, p. 1 .

Hicks, Nancy. "Food Stamp Price Freeze Voted by House, 374 to 38 ," The New York Times, February 5, 1975, p. 1 .

Hicks, Nancy. "Senate, 76-8 votes Freeze in Prize of Food Stamps," The New York Times, February 6, 1975, p. 1 .

Hicks, Nancy. "Use of Food Stamps Soars as Jobless Turn to Them," The New York Times, January 29, 1975, p. I. 
King, Sech S. "Many University Students are Turning U.S. Food Stamps into a Form of Scholarship," The New York Times, January 2, 1975, p. 12 .

"Layoff Cushion: Unions Teach Jobless Members How to Get Food Stamps," Labor Letter, The Wall Street Journal, November 12, 1974, p. 1 . 